\title{
Thermal-optical analysis for the measurement of elemental carbon (EC) and organic carbon (OC) in ambient air a literature review
}

\author{
A. Karanasiou ${ }^{1}$, M. C. Minguillón ${ }^{1}$, M. Viana ${ }^{1}$, A. Alastuey ${ }^{1}$, J.-P. Putaud ${ }^{2}$, \\ W. Maenhaut ${ }^{3}$, P. Panteliadis ${ }^{4}$, G. Močnik ${ }^{5}$, O. Favez ${ }^{6}$, and T. A. J. Kuhlbusch ${ }^{7}$ \\ ${ }^{1}$ Institute of Environmental Assessment and Water Research (IDAEA), Spanish Research \\ Council (CSIC), Barcelona, Spain \\ ${ }^{2}$ European Commission, Joint Research Centre, Institute of Environment and Sustainability, \\ via E. Fermi, 2749, 21027 Ispra, Italy \\ ${ }^{3}$ Department of Analytical Chemistry, Ghent University, Gent, 9000, Belgium \\ ${ }^{4}$ GGD, Department of Air Quality, Public Health Service Amsterdam, 1018WT, the Netherlands \\ ${ }^{5}$ Aerosol d.o.o., Ljubljana, Slovenia \\ ${ }^{6}$ Institut National de l'Environnement Industriel et des Risques, Parc Technologique ALATA, \\ 60550 Verneuil-en-Halatte, France \\ ${ }^{7}$ Institute of Energy and Environmental Technology e.V. (IUTA), Bliersheimerstraße 58-60, \\ 47229 Duisburg, Germany
}

Measurement of elemental carbon $(E C)$ and organic carbon (OC)

A. Karanasiou et al.

\section{Title Page}

Abstract Introduction

Conclusions

References

Tables

Figures

\section{4}

4

Back

Full Screen / Esc

Printer-friendly Version

Interactive Discussion 
Received: 22 July 2015 - Accepted: 20 August 2015 - Published: 16 September 2015 Correspondence to: A. Karanasiou (angeliki.karanasiou@idaea.csic.es)

Published by Copernicus Publications on behalf of the European Geosciences Union.

AMTD

8, 9649-9712, 2015

\section{Measurement of elemental carbon (EC) and organic carbon (OC)}

A. Karanasiou et al.

Title Page

Abstract

Introduction

Conclusions

References

Tables

Figures

14

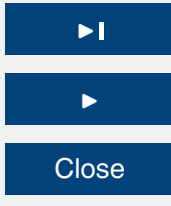

Back

Close

Full Screen / Esc

Printer-friendly Version

Interactive Discussion 


\section{Abstract}

Thermal-optical analysis is currently under consideration by the European standardization body (CEN) as the reference method to quantitatively determine organic carbon $(\mathrm{OC})$ and elemental carbon (EC) in ambient air. This paper presents an overview of the 5 critical parameters related to the thermal-optical analysis including thermal protocols, critical factors and interferences of the methods examined, method inter-comparisons, inter-laboratory exercises, biases and artifacts, and reference materials. The most commonly used thermal protocols include NIOSH-like, IMPROVE_A and EUSAAR_2 protocols either with light transmittance or reflectance correction for charring. All thermal evolution protocols are comparable for total carbon (TC) concentrations but the results vary significantly concerning $\mathrm{OC}$ and especially $\mathrm{EC}$ concentrations. Thermal protocols with a rather low peak temperature in the inert mode like IMPROVE_A and EUSAAR_2 tend to classify more carbon as EC compared to $\mathrm{NIOSH}$-like protocols, while charring correction based on transmittance usually leads to smaller EC values compared to reflectance. The difference between reflectance and transmittance correction tends to be larger than the difference between different thermal protocols. Nevertheless, thermal protocols seem to correlate better when reflectance is used as charring correction method. The difference between EC values as determined by the different protocols is not only dependent on the optical pyrolysis correction method, but also on the chemical properties of the samples due to different contributions from various sources. The overall conclusion from this literature review is that it is not possible to identify the "best" thermal-optical protocol based on literature data only, although differences attributed to the methods have been quantified when possible.

\section{Introduction}

25 Carbonaceous material accounts for a large and often dominant fraction of particulate matter, PM (Putaud et al., 2010, 2004; Fuzzi et al., 2006) that receives the attention
AMTD

8, 9649-9712, 2015

Measurement of elemental carbon (EC) and organic carbon (OC)

A. Karanasiou et al.

\section{Title Page}

Abstract Introduction

Conclusions References

Tables Figures

\section{4}

4

Back

Printer-friendly Version

Interactive Discussion 
of the climate, air pollution and health research communities (Lim et al., 2012; Shindell et al., 2012; Janssen et al., 2012). Particulate carbon (total carbon, TC) may be broadly divided into three categories: organic carbon (OC), elemental carbon (EC) and inorganic carbon (IC), mostly present as carbonate carbon (CC). OC is either directly 5 emitted into the atmosphere or formed by the condensation of compounds produced by the atmospheric photo-oxidation and polymerisation of organic species (Jimenez et al., 2009). In contrast, EC is exclusively of primary origin and emitted by the incomplete combustion of carbon-based fuels, principally wood used for residential heating and fossil fuels used in transportation, power generation, and industrial processes (Fuzzi 10 et al., 2006). CC is present in natural ground and building/demolition dust which can be resuspended.

The terms EC, Black Carbon (BC), soot, and light absorbing carbon (LAC) have often been used loosely and interchangeably in the literature (Petzold et al., 2013). Soot, the product of incomplete combustion of any carbon containing fuels, is used by the In15 tergovernmental Panel on Climate Change to denote any light-absorbing, combustiongenerated aerosols, whereas BC refers to the optical properties of soot defined as an ideally light-absorbing substance composed of carbon (Petzold et al., 2013; Baumgardner et al., 2012). Light-absorbing is not strictly specific to carbon, but BC features a much larger mass absorption cross-section than other aerosol constituents. In contrast, EC refers to chemical properties, i.e. to thermally-refractory carbon, including graphitic structures. The term EC is used when total carbon is gasified from the sample, and EC is differentiated from OC based on refractiveness properties (i.e. thermal methods) or optical measurements during the course of the thermal analysis (thermaloptical methods).

25 Thermal methods make use of the thermal refractivity of EC, which does not volatilize in an inert atmosphere at temperatures below $\sim 700^{\circ} \mathrm{C}$. EC can only be gasified by oxidation starting at temperatures above $340^{\circ} \mathrm{C}$ (Petzold et al., 2013; Schmid et al., 2001). Therefore $\mathrm{OC}$ might be defined as the carbon fraction that evolves under a heating cycle in an inert atmosphere, and EC as the fraction which evolves during a subsequent

\section{AMTD}

8, 9649-9712, 2015

Measurement of elemental carbon (EC) and organic carbon (OC)

A. Karanasiou et al.

Title Page

Abstract Introduction

Conclusions References

Tables Figures

14

4

Back

Printer-friendly Version

Interactive Discussion 
heating step in an oxygen-containing gas mixture. However, some organic compounds can easily pyrolyze or "char" during the inert mode of the analysis. The char that is formed during the analysis process, if not properly accounted for, would be incorrectly reported as EC present in the original sample. Thermal-optical methods have been 5 developed in which the continuous monitoring of the optical properties (reflectance or transmittance) of the filter sample during the analysis is used to correct for charring (Chow et al., 1993; Birch and Cary, 1996).

The European Union (EU) has issued a directive (2008/50/EC) which requires the monitoring of organic carbon and elemental carbon in $\mathrm{PM}_{2.5}$ at selected rural back10 ground sites from mid-2010. The monitoring program of the Convention on long-range transport of air pollutants (EMEP) also includes the measurement of OC and EC in $\mathrm{PM}_{10}$. The technical report from The European Committee for Standardization, CEN (CEN/TR 16243, 2011) recommends thermal-optical analysis to determine OC and EC concentrations in ambient air, but no European standard method exists yet. In this 15 work, we provide an overview of scientific papers, protocols, guidelines, and reports related to thermal-optical methods for the determination of EC and OC. Many parameters are studied such as the critical factors and interferences of the methods examined, inter-comparison of the methods, biases and artifacts, reference materials and inter-laboratory exercises. The present literature review was conducted to serve as the scientific basis on the discussion over the performance and applicability of measurement methods of airborne $\mathrm{EC}$ and $\mathrm{OC}$ in $\mathrm{PM}_{2.5}$ in accordance to the new Air Quality Directive 2008/50/EC.

\section{Thermal-optical analysis}

During the thermal analysis a fraction of the $\mathrm{OC}$ chars or pyrolyzes under the inert 25 like the EC, can only be converted into vapor at higher temperature or in presence of $\mathrm{O}_{2}$. This pyrolytic fraction, called pyrolytic carbon (PC), can be erroneously identified

\section{AMTD}

8, 9649-9712, 2015

Measurement of elemental carbon (EC) and organic carbon (OC)

A. Karanasiou et al.

\section{Title Page}

Abstract Introduction

Conclusions References

Tables Figures

14 4

Back

Full Screen / Esc

Printer-friendly Version

Interactive Discussion

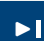
Close 
as EC. To overcome this interference, Huntzicker et al. (1982) developed a thermaloptical analysis method by incorporating an optical correction procedure in the thermal analysis. The light reflectance of the sample, which was continuously monitored by a He-Ne laser-based system, was used for charring correction.

A modified version of the Huntzicker et al. (1982) instrument designed by Chow et al. (1993) at the Desert Research Institute (DRI) is known as the DRI carbon analyzer. A temperature protocol named IMPROVE, was specifically developed to be applied to the Interagency Monitoring of PROtected Visual Environments network in the USA. Carbonaceous vapours are converted after volatilisation to $\mathrm{CH}_{4}$ (see temper10 ature steps in Table 1) and quantified with a flame ionization detector, FID. Similarly to the method of Huntzicker et al. (1982) the sample reflectance is monitored to correct for charring and the method is called the thermal-optical reflectance (TOR). A few years later, the Sunset laboratory instrument (Sunset Laboratories Inc.) was developed based on the same principle, but using transmittance monitoring to correct for charring 15 (Birch and Cary, 1996). The thermal-optical transmittance (TOT) method was designed for the analysis of the carbonaceous fraction of particulate diesel exhaust based on the National Institute of Occupational Safety and Health method 5040 (NIOSH 5040) and the thermal protocol developed was called NIOSH (see Table 1). Additionally, the Sunset Carbon Aerosol Analysis Field Instrument was developed, which measures OC and EC in situ and in near-real time, based on the same analysis principle as in the Sunset laboratory instrument (Bae et al., 2004). However, the field instrument will not be further described in this review as it performs on-line measurements while the lab instruments can analyze samples from various sites.

The rationale of the optical correction method either with transmittance or with reflectance is based on the fact that EC does not volatilize up to very high temperatures but its release occurs only when oxygen is present. Charring is evidenced by the decrease of the filter sample reflectance or transmittance. When PC evolves, the sample reflectance or transmittance increases to reach its original value, as the charred $\mathrm{OC}$ has been removed. The OC/EC split point is usually defined in this manner. It is as-

\section{AMTD}

8, 9649-9712, 2015

Measurement of elemental carbon (EC) and organic carbon (OC)

A. Karanasiou et al.

\section{Title Page}

Abstract Introduction Conclusions References Tables Figures

14 4 Back
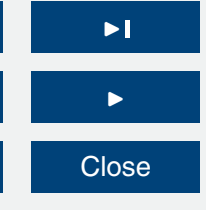

Full Screen / Esc

Printer-friendly Version

Interactive Discussion 
sumed that the carbonaceous material released after the split point is quantitatively nearly equal to the EC that was originally on the filter, based on assumptions related to the composition of the sample and the optical properties of PC.

It should be mentioned that traditionally the DRI analyzer uses reflectance (TOR) 5 correction and the Sunset Laboratory instrument the transmission (TOT) correction, but both instruments have currently installed dual optics where simultaneous TOR and TOT corrections are possible. The latest instrumental development in thermal-optical analysis is the DRI 7 wavelength thermal-optical analyzer (Chen et al., 2015) using 7 different lasers for TOT/TOR corrections, resulting in 14 different wavelength depen- dent split points (TOT or TOR correction at each of the wavelengths). Since EC and PC have different optical properties this information may prove useful in characterization of PC during the analysis as it may allow a more accurate separation of the EC contained in the sample and the PC generated during the analysis. This should prove especially useful in the constraining of the separation between OC and EC in samples loaded with 15 biomass smoke, containing water-soluble and light absorbing organic compounds.

\subsection{Thermal-optical analysis protocols}

Nowadays, both the Sunset and the DRI carbon analyzers are commercially available instruments and are capable to operate any thermal protocol. Table 1 summarizes several of the temperature protocols that have been applied to determine ambient OC and EC concentrations. Most protocols like the ACE-Asia, STN, CalTech, HKGL and MSC1 protocols (e.g., Schauer et al., 2003; Sin et al., 2002; Yang and Yung, 2002; Peterson and Richards, 2002) are NIOSH-like protocols, being modified versions of the Birch and Cary (1996) and Birch et al. (1998) protocols, with maximum temperatures in the $\mathrm{He}$ mode found in the range $820-900^{\circ} \mathrm{C}$ and final temperatures in the $\mathrm{He}-\mathrm{O}_{2}$ 25 mode set at $850-940^{\circ} \mathrm{C}$. NIOSH-like protocols are identified as $\mathrm{NIOSH}-840, \mathrm{NIOSH}-$ 850 or $\mathrm{NIOSH}-870$ by the maximum temperature applied in the inert mode. Occasionally NIOSH-like protocols are also called "Quartz" (Querol et al., 2013; Quincey et al., 2009) or "Quartz.par" protocol (Yttri et al., 2009).

\section{AMTD}

8, 9649-9712, 2015

Measurement of elemental carbon (EC) and organic carbon (OC)

A. Karanasiou et al.

\section{Title Page}

Abstract

Conclusions

Tables References Figures

14

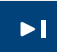

4

Back

Printer-friendly Version

Interactive Discussion 
The IMPROVE network currently uses IMPROVE_A, which is a modified version of the IMPROVE protocol to accommodate for an upgrade of the DRI analyzer. After the temperature calibration of the DRI analyser, the temperature steps of the IMPROVE protocol were increased by $20-40{ }^{\circ} \mathrm{C}$ (Chow et al., 2007). The main difference from $5 \mathrm{NIOSH}$-like protocols is the lower temperature in the He phase of the analysis $\left(580^{\circ} \mathrm{C}\right)$ and the analysis time. The IMPROVE protocol advances from one temperature to the next one when a well-defined carbon peak has evolved, resulting in variable and generally longer analysis times.

Recently, in the framework of the EU-project EUSAAR (European Supersites for At10 mospheric Aerosol Research, www.eusaar.net), the thermal-optical analysis protocol EUSAAR_2 was developed (using transmittance for charring correction) for European regional background sites (EMEP network) in order to improve the accuracy of the discrimination between $\mathrm{OC}$ and EC. The use of lower temperature steps in the He-mode and longer residence times aimed at the reduction of pyrolysis and at a more complete 15 evolution of OC (Cavalli et al., 2010).

Table 2 provides the analytical specifications of the most commonly used temperature protocols (units are given in $\mu \mathrm{g} \mathrm{cm}^{-2}$ of filter). The range for the $\mathrm{NIOSH}$ protocol is 0.7 to $70 \mu \mathrm{g} \mathrm{cm}^{-2}$ and the limit of detection (LOD) was calculated at $0.15 \mu \mathrm{g} \mathrm{cm}^{-2}$ (Birch and Cary, 1996; Peterson and Richards, 2002). The operational range for the 20 IMPROVE_A protocols is $0.2-750 \mu \mathrm{g} \mathrm{Cm}^{-2}$ and the LOD $0.2 \mu \mathrm{g} \mathrm{Cm}^{-2}$ (Chow et al., 1993). The EUSAAR_2 protocol was designed and tested on samples collected during different seasons and at various sites in Europe, with filter loadings ranging from 5 to $62 \mu \mathrm{g} \mathrm{Cm}^{-2}$. The residence times at each temperature step were selected such that the various carbon peaks are clearly separated and the uncertainty in the EC determi-

\section{AMTD}

8, 9649-9712, 2015

Measurement of elemental carbon (EC) and organic carbon (OC)

A. Karanasiou et al.

\section{Title Page}

Abstract Introduction

Conclusions References

Tables Figures

14

4

Back

Printer-friendly Version

Interactive Discussion 


\subsection{Critical factors in thermal-optical analysis}

\subsubsection{Temperature calibration}

Typically, the sample oven temperature is measured in thermal-optical instruments using a temperature sensor near, but not precisely at, the sample. However, temperature

5 variability within the oven may result in different temperatures at the sample and the sensor (Phuah et al., 2009). Sample temperatures have been found to differ from sensor temperatures by 10 to $85^{\circ} \mathrm{C}$ in both the DRI and Sunset analyzers by IMPROVE_A, $\mathrm{NIOSH}$-like and EUSAAR_2 protocols (Chow et al., 2005b; Phuah et al., 2009; Pavlovic et al., 2014; Panteliadis et al., 2015). Chow et al. (2005b) demonstrated that temperature biases of 14 to $22^{\circ} \mathrm{C}$ can influence the carbon fraction measurement in thermaloptical analysis. Therefore, the correlation between sample temperature and the sensor temperature should be calibrated so that the thermal protocol can truly reflect the sample temperature during the analysis.

\subsubsection{Maximum temperature in the inert mode}

15 Many researchers report that, in the thermal-optical method, the results depend upon the operational parameters, and in particular on the analysis temperature program including the temperature ramp step and the duration of the plateaus (Schauer et al., 2003; Chow et al., 2001, 2005a). Application of a too high maximum temperature in the inert mode, Tmax (the temperature of the last step in the inert mode) may cause the premature evolution of EC and light absorbing carbon that contains both $\mathrm{PC}$ and $\mathrm{EC}$ and also promote charring while a very low Tmax may result in an overestimation of the EC concentration due to the incomplete evolution of $\mathrm{OC}$ in the He mode and the evolution of $\mathrm{CC}$ in the $\mathrm{He}-\mathrm{O}_{2}$ mode (Subramanian et al., 2006). EC concentrations have been found to decrease linearly with the increase of the Tmax in the He mode

25 (Subramanian et al., 2006; Zhi et al., 2009; Maenhaut et al., 2009; Kuhlbusch et al., 2009).
AMTD

8, 9649-9712, 2015

Measurement of elemental carbon (EC) and organic carbon (OC)

A. Karanasiou et al.

Title Page

Abstract Introduction

Conclusions References

Tables Figures

14 4

Back

Full Screen / Esc

Printer-friendly Version

Interactive Discussion 


\subsubsection{Charring and charring correction}

Charring depends on many factors, including the amount and type of organic compounds, temperature steps in the analysis, the residence time at each temperature step, and the presence of certain inorganic constituents (Yu et al., 2002).

Yu et al. (2002) found that water-soluble organic compounds WSOC are responsible for a large fraction (13-66\%) of charring in thermal-optical analysis. The extent of the charring from WSOC was found to increase with the WSOC loading up to a certain value. Piazzalunga et al. (2011) demonstrated that the removal of WSOC from ambient samples reduces the differences observed between different thermal protocols and slightly improves their comparability. Charring is also influenced by the presence of inorganic constituents such as $\mathrm{NH}_{4} \mathrm{HSO}_{4}$ that can increase PC formation by a factor of 2 to 3 (Yu et al., 2002). Charring can be reduced when the residence time at each temperature step in the $\mathrm{He}$ atmosphere is sufficiently long to allow for maximum $\mathrm{C}$ evolution at each step (Cavalli et al., 2010).

Thermal-optical methods assume that: (1) PC caused by charring during the inert mode is more easily oxidized than EC, or (2) the specific attenuation cross section, $\sigma$ of $P C$ is similar to the specific attenuation cross section of the original EC on the filter. If either of these assumptions is correct, then the method will be quantitative for $\mathrm{OC}$ and EC. However, PC and EC and non light-absorbing carbon co-evolve during the oxidizing mode and, even prematurely, during the He-mode at high temperatures depending on the protocol used and they have been shown to have significantly different values of attenuation cross section (Cavalli et al., 2010 and references therein). The true EC concentrations can be either overestimated or underestimated depending on whether the fraction of $\mathrm{PC}$ that is burned after the $\mathrm{EC} / \mathrm{OC}$ split point has a higher or a lower $\sigma$ ganic precursors, which vary greatly among aerosols collected from different locations and at different times. As a result, the magnitude of the uncertainty arising from the 
incorrect $\mathrm{EC} / \mathrm{OC}$ split is expected to vary from one aerosol sample to another Yang and Yu (2002).

\subsubsection{Dependence of OC/EC split on aerosol type}

The relative amount of carbon allocated as OC and EC is sensitive to the type of 5 aerosol collected (Chow et al., 2001; Schauer et al., 2003). The OC/EC split for wood smoke source samples, extracts of organic compounds from wood smoke and woodstove smoke is influenced by the temperature protocol; such samples exhibit significant charring while a carbon black sample has the same split between OC and EC regardless of the temperature protocol (Khan et al., 2012; Schauer et al., 2003; Reisinger et al., 2008; Maenhaut et al., 2009; Soto-Garcia et al., 2011). The explanation is found in the composition of wood and biomass burning emissions, which contain significant amounts of WSOC that appear highly amenable to charring. Moreover wood burning EC has been proven to be less refractory than fossil fuel burning EC (Zhang et al., 2012). In addition $\mathrm{K}$ and $\mathrm{Na}$ that are abundant in biomass burning emissions can alter the decomposition temperature of EC and provoke premature oxidation (Novakov and Corrigan, 1995). On the other hand, samples from traffic sites form little PC during thermal-optical analysis, possibly due to the high diesel component which contains non pyrolyzing organic matter, such as PAHs (Khan et al., 2012). Samples containing high amounts of resuspended soil and road dust can cause the premature evolution of LAC compounds in the inert mode due to increased oxidation at high temperatures by metal oxides present in soil and road dust (Khan et al., 2012). If this happens, the critical issue is to determine the type of LAC that evolves. If the LAC evolving in the He-mode at high temperature is pure PC, as suggested by Yu et al. (2002), this does not produce any bias in the OC and EC determination. However, Subramanian et al. (2006) temperatures can be either EC or PC or a combination of them.

8, 9649-9712, 2015

Measurement of elemental carbon (EC) and organic carbon (OC)

A. Karanasiou et al.

Title Page

Abstract Introduction

Conclusions References

Tables Figures

14 $\rightarrow$ I

4

Back

Full Screen / Esc

Printer-friendly Version

Interactive Discussion 


\subsubsection{Dependence of OC/EC split on sample oven soiling}

The quartz oven hosting the sample during analysis is gradually soiled by oxidation and inorganic salts originating from filter matrices (when containing binders) and/or loaded samples. Chiappini et al. (2014) evidenced possible impact of the oven soiling on the ${ }_{5}$ EC/OC split point, especially for samples exhibiting high EC and PC amounts.

\subsubsection{Instrument parameters influencing the analysis}

The time necessary for the gaseous compounds desorbed to reach the FID unit from the filter is defined as transit time and is an instrument-specific parameter. As the transit time is taken into account to determine the split point, an incorrect transit time will result 10 in a shift of the split point and thus incorrect concentration values for the OC and EC fractions. Maenhaut et al. (2004) and Panteliadis et al. (2015) have indicated that the FID response for the oxidized PC is somewhat delayed because of the laser-FID transit time resulting in the erroneous determination of the split point.

As discussed in the sections above, several factors directly influence the split point 15 between EC and OC, but since no true split point could be defined so far, no direct judgments on how to balance the different factors can be made here.

\section{Biases in thermal-optical analysis}

Biases in thermal-optical analysis methods can come from the following: (i) non-uniform particle deposits on the filter, (ii) OC loading in blank filters, (iii) organic vapour filter ad20 sorption, (iv) catalytic oxidation interactions between OC, EC, and non-carbonaceous material in the sampled particles, and (vi) light-absorbing organic matter that affects laser correction. As the filter homogeneity is a common source of possible interference for the determination of all ambient aerosol constituents it is not discussed specifically

AMTD

8, 9649-9712, 2015

Measurement of elemental carbon

(EC) and organic carbon (OC)

A. Karanasiou et al.

Title Page

Abstract

Conclusions

Tables ces

\section{Figures}

14

4

Back

$>$ I

$\checkmark$

Close

Full Screen / Esc

Printer-friendly Version

Interactive Discussion 
in this review. Inhomogeneities determined elsewhere were normally found in the range 3-5\% of variability (e.g.: John and Reischl, 1980; John and Wall, 1983).

\subsection{OC loading in blank filters}

Quartz fibre filters may adsorb volatile organic compounds very easily because of the 5 high active surface resulting in the increase of blank levels for OC (Chai et al., 2012). Contamination of filters may also occur during transport and at the sampling site depending on the holder/container used for transport and during sampling. In order to estimate the carbon present in the blank filter or adsorbed on it, laboratory blank filters and field blank filters are used.

\subsubsection{Laboratory blank filters}

Quartz filters may be submitted to a thermal treatment (pre-firing) in the laboratory prior to sampling in order to remove volatile adsorbed carbon and therefore reduce their OC content. The EMEP draft protocol for EC/OC determination at EMEP sites (available at http://www.nilu.no/projects/ccc/manual/index.html) recommends pre-firing 15 at $850^{\circ} \mathrm{C}$ for $3 \mathrm{~h}$. A similar protocol is followed by the US networks (STN, IMPROVE and SEARCH networks) where filters are pre-fired at $900^{\circ} \mathrm{C}$ for $3 \mathrm{~h}$ under a slow stream of filtered air. The high temperatures used in pre-firing may increase the adsorption capacity of the filters. Thus, the CEN/TC 264 report (CEN/TR 16243, 2011) suggests pre-firing at lower temperatures (a minimum of $500^{\circ} \mathrm{C}$, for at least $1 \mathrm{~h}$ ), whereas $\operatorname{Arp}$ et al. (2007) suggest more gentle procedures, such as pre-firing at temperatures < $400^{\circ} \mathrm{C}$ or possibly washing the filters with an organic solvent.

The adsorption capacity of organic gases is specific for each filter, varying between filters from the same brand, type, and even from the same lot number or box (Kirchstetter et al., 2001). Mean OC concentrations determined in blank quartz filters are in
AMTD

8, 9649-9712, 2015

Measurement of elemental carbon (EC) and organic carbon (OC)

A. Karanasiou et al.

Title Page

Abstract Introduction

Conclusions References

Tables Figures

14

4

Back

Printer-friendly Version

Interactive Discussion 
Figure 1 shows the mean, median, and 25 and 75 percentiles of the OC blank concentrations determined for a total of 128 PALL Quartz filters (Pall Tissuquartz 2500QAT, $150 \mathrm{~mm}$ ) in the IDAEA-CSIC laboratory for the period 2012-2013 (IDAEA-CSIC unpublished results). These filters are commonly used for offline OC/EC determina5 tion after high-volume sampling. The filters were baked at $200^{\circ} \mathrm{C}$ for $4 \mathrm{~h}$ and packaged in the same way as the filters used for sampling, but kept in the laboratory until the analysis. The average OC blank concentration was $0.80 \pm 0.39 \mu \mathrm{g} \mathrm{cm}^{-2}$. The results are compared to those obtained for the new Whatman ultra-pure Quartz filters $(\mathrm{QM}-\mathrm{H}$, $150 \mathrm{~mm}), 127$ filters analyzed in 2014 without pre-firing, with slightly higher concentrations of OC $\left(1.22 \pm 1.11 \mu \mathrm{g} \mathrm{cm}^{-2}\right.$, Table 3$)$.

Laboratory blank filters were analyzed by the Netherlands research project on Particulate Matter (ten Brink et al., 2009). For this study, Whatman QM- A quartz filters $(47 \mathrm{~mm})$ were used without pre-firing. The blank filters were analyzed as received from the factory, taken from batches that were opened shortly before analysis. The average 15 value was $2.4 \mathrm{\mu g} \mathrm{cm}^{-2}$ (Table 3). It was consistently observed that filters from the top of a stack contained high OC values $\left(\sim 6 \mu \mathrm{g} \mathrm{cm}^{-2}\right.$ on average). These values were even higher than those of the average field blank value. Further down the stack of filters, the values rapidly decreased down to $\sim 0.4 \mathrm{\mu g} \mathrm{cm}^{-2}$, on average, in the middle of the stack, and $1.2 \mu \mathrm{g} \mathrm{cm}^{-2}$ at the bottom. The concentrations determined for the top filters should be considered as relatively high when compared with usual values in samples.

Chai et al. (2012) determined the concentrations of OC and EC for blank quartz filters (2500QAT-UP) before and after pre-firing at $600^{\circ} \mathrm{C}$ for $2 \mathrm{~h}$. The levels of EC were negligible for both baked and unbaked filters. The levels of $\mathrm{OC}$ were lower for the prefired filters $\left(0.22 \pm 0.11 \mathrm{\mu g} \mathrm{cm}^{-2}\right.$, on average) as compared with the non-pre-fired filters $25 \quad\left(0.38 \pm 0.06 \mu \mathrm{g} \mathrm{cm}^{-2}\right.$, on average). The decrease of OC concentrations was considered not significant when compared with their usual sample loadings. As described in the section dealing with sampling artifacts, several authors report that pre-firing the filters may alter their sorption properties and enhance the occurrence of positive sampling artifacts.

\section{AMTD}

8, 9649-9712, 2015

Measurement of elemental carbon (EC) and organic carbon (OC)

A. Karanasiou et al.

\section{Title Page}

Abstract Introduction

Conclusions References

Tables Figures

14

4

Back

Printer-friendly Version

Interactive Discussion 


\subsubsection{Field and trip blank filters}

Trip blanks are used to assess artifacts associated with handling, transport and storage. Field blanks are additionally placed in the instrument during e.g. 1 week without forcing the passage of air through them, or passing air during a brief time period (from

5 a few seconds to $1 \mathrm{~min}$ ). Some studies assume that field blanks can be used as a proxy for the adsorption artifact during active sampling (Watson et al., 2007). However, filters may be subjected to a number of changes affecting the net absorption of gaseous carbon during sampling that are not reflected in the field blanks (Maimone et al., 2011), such as changes in ambient air concentrations of gaseous carbon, ambient temperature or pressure drop due to filter loading. EMEP recommends to analyse one field blank per week and to subtract its OC concentration from the sample OC concentrations when the positive and negative artifacts are not avoided or quantified (by means of a back-up quartz filter OC behind a quartz filter, QBQ; or behind a Teflon filter, QBT; denuder). Moreover, it has to be considered that part of the adsorbed gases may volatilize during sampling. Thus, Yttri et al. (2007) found that adsorbed carbon in the field blanks would partially evaporate, decreasing by as much as a factor of two, when passing a clean air flow through.

Field blank filters have been analyzed in a number of studies with different results. Yttri et al. (2007) found negligible EC concentrations and OC concentrations between 0.4 and $1.9 \mu \mathrm{g} \mathrm{Cm}^{-2}$ in field blanks collected at EMEP European sites. Ten Brink et al. (2009) found $3.8 \mu \mathrm{g} \mathrm{C} \mathrm{cm}^{-2}$ adsorbed in Whatman quartz field blanks on average (although higher concentrations were recorded for a few field blanks), regardless of the type of environment (rural-traffic-urban). Maenhaut et al. (2006) found high blank OC concentrations, even exceeding some sample concentrations, and negligible EC concentrations in a set of field blank pre-fired Whatman quartz fiber filters. This adsorption was found to be seasonally dependent. Also in later studies, similar high OC field blank values were observed $\left(\sim 4 \mu \mathrm{g} \mathrm{cm}^{-2}\right)$, but the values did not depend on the site nor on the season (Maenhaut and Claeys, 2011, 2012).
AMTD

8, 9649-9712, 2015

Measurement of elemental carbon (EC) and organic carbon (OC)

A. Karanasiou et al.

\section{Title Page}

Abstract Introduction

Conclusions References

Tables Figures

14 4 Back

Printer-friendly Version

Interactive Discussion 
The seasonality found for the field blanks (pre-fired Whatman quartz fiber filters) by Maenhaut et al. (2006) contrasts with a number of studies in the USA, which found that trip and field blanks have similar loadings that may vary significantly depending on sampler type but do not vary significantly by season, ambient temperature, or loca5 tion (Solomon et al., 2000: no information about the brand; Flanagan et al., 2002: no information about the brand; Maimone et al., 2011: pallflex and whatman quartz fiber filters). The similarity between trip and field blanks and across seasons in the US studies suggests that the mounting process and short ambient exposure contribute little to the blank filter loadings. The differences in blank concentrations depending on the sam10 pler can be attributed to the differences in the cassettes used for transport, which are sampler-specific, made up of different materials, and occasionally containing grease (Solomon et al., 2000; Flanagan el al., 2002; Maimone et al., 2011).

To minimize carbon adsorption, EMEP recommends storing pre-fired filters at $-18^{\circ} \mathrm{C}$ prior to being exposed and after exposure until they are analysed. Filters should be 5 stored in petri dishes (e.g., Millipore/Whatman) or in pre-fired $\left(<500^{\circ} \mathrm{C}\right.$ for $3 \mathrm{~h}$ ) aluminium foil (http://www.nilu.no/projects/ccc/manual/download/Protocol_EC_OC.doc). Other recommendations include the analysis of 2-3 blank filters from each box/batch and reject those boxes/batches with concentrations exceeding a specific value. Field blanks do not reflect the net artifact during sampling but they can be used to identify any problems related to transport and storage. The field blank values should not be subtracted from the sample OC concentrations as this may lead to overestimation or underestimation of the artifact-free particulate OC.

\subsection{Sampling artifacts}

Filters can take up volatile carbon and may lose collected semi-volatile compounds at 25

the same time (Turpin et al., 2000). Under typical sampling conditions adsorption is the dominant artifact in the sampling of particulate $\mathrm{OC}$, and longer sampling periods reduce the percentage of collected material that is adsorbed (Turpin and Huntzicker, 1994). In relative terms the positive artifact is generally most severe for samples with lowest $\mathrm{OC}$
AMTD

8, 9649-9712, 2015

Measurement of elemental carbon (EC) and organic carbon (OC)

A. Karanasiou et al.

\section{Title Page}

Abstract Introduction

Conclusions References

Tables Figures

14

4

Back

Full Screen / Esc

Printer-friendly Version

Interactive Discussion

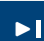

lose 
loadings (Putaud and Cavalli, 2006). The adsorbed OC is distributed throughout the filter, as evidenced by visible darkening of the back side of the filter when it chars during heating in a non-oxidizing atmosphere (Chow et al., 2004). The methods available to minimise adsorption artifacts and to assess their magnitude are well described (ten 5 Brink et al., 2004; Watson et al., 2007 and references therein) but are considered too elaborate for routine measurements in urban or regional background monitoring networks (ten Brink et al., 2009), even if configurations have been successfully tested (e.g.: within Aerosol, Clouds, and Trace Gases Research Infrastructure Network, ACTRIS, www.actris.eu).

10 The occurrence of positive and negative sampling artifacts depends on a number of factors:

- Sampling face velocity: The influence of OC sampling artifacts on quartz filters operated at $47 \mathrm{~cm} \mathrm{~s}^{-1}$ (case of the EU reference high-volume samplers operating at $30 \mathrm{~m}^{3} \mathrm{~h}^{-1}$ with $15 \mathrm{~cm}$ diameter filters) may be much lower than that for low-volume collectors, with usually lower face velocities (J.L. Besombes, personal communication). In the US, the Speciation Trends Network or Chemical Speciation Network (STN/CSN) carbon measurements aims to minimize artifacts by increasing the face velocity (e.g. from 23.7 to $107.2 \mathrm{~cm} \mathrm{~s}^{-1}$ ) via a higher flow rate (e.g. $22.8 \mathrm{lpm}$ instead of $16.7 \mathrm{lpm})$ and a smaller deposit area $\left(3.53 \mathrm{~cm}^{2}\right.$ instead of $11.76 \mathrm{~cm}^{2}$ ). However, recommendations for a higher flow rate and a smaller deposit area ignore negative artifacts.

- Filter substrate: Filters manufactured by the same company but having different lot numbers exhibit variable adsorption capacity (Kirchstetter et al., 2001). Thus, a pair of front and back filter composed of filters from different lots may lead to significant under- or overestimation of particulate OC concentration. The use of the thinnest quartz fibre filters possible is recommended to minimise artifacts (Arp et al., 2007).

AMTD

8, 9649-9712, 2015

Measurement of elemental carbon (EC) and organic carbon (OC)

A. Karanasiou et al.

Title Page

Abstract Introduction

Conclusions References

Tables Figures

14 $>$ I

4

Back

Full Screen / Esc

Printer-friendly Version

Interactive Discussion 
- Sampling duration: The use of a back-up filter as a method to correct for the positive artifact (see explanation below) leads to under-correction if the sampling time is short (few hours) (Kirchstetter et al., 2001). The accuracy of the method improves with increased sampling time.

- Pre-firing of filters: Pre-firing the filters may increase their sorption capacity, and even make it irreproducible (Arp et al., 2007), therefore it is only recommended, provided it is not carried out at too high temperatures, if the blank filters contain too large amounts of OC (Arp et al., 2007; CEN/TR 16243, 2011).

- Aerosol type: The concentration of gases which can be adsorbed may be higher in urban than in non-urban environments (e.g., Watson et al., 2007). The oxidation of low-volatility hydrocarbons is a main channel for secondary aerosol formation. Fresh plumes may contain substantial amounts of semi-volatile organic compounds (SVOCs) in both gaseous and particle phases that come into equilibrium as the plumes age. In rural and remote atmospheres, many SVOCs will have evaporated or converted to more stable compounds. In this case, back-up filter OC may be similar to the OC field blank. Urban locations, on the contrary, experience more fresh emissions and with higher contributions from adsorbable vapors. These materials are more likely to be adsorbed when air is drawn through the filter than on the passive field blank (Watson et al., 2007). Eatough et al. (2003) evidenced that a substantial amount of back-up filter OC originates from positive artifacts when the contribution of biomass burning is important, in Utah (US).

- Ambient temperature: For studies at low or near-zero temperatures, the use of an upstream denuder to determine gaseous organic concentrations may lead to less artifacts than setups involving back-up filters and downstream sorbents (Arp et al., 2007). Due to the higher SVOC concentrations, higher positive artifacts are expected for sampling periods with high ambient temperature than for colder periods (Watson et al., 2007; Viana et al., 2006b).

\section{AMTD}

8, 9649-9712, 2015

Measurement of elemental carbon (EC) and organic carbon (OC)

A. Karanasiou et al.

\section{Title Page}

Abstract Introduction

Conclusions References

Tables Figures

14

4

Back

Printer-friendly Version

Interactive Discussion 
Different approaches are used in research and in the networks to quantify and correct for the OC artifact, such as the use of back-up filters, parallel sampling trains, blank corrections, and denuders, among others. The amount of $\mathrm{OC}$ adsorbed onto a quartz filter can be determined by performing a double experiment with (a) a front quartz filter 5 and a quartz back-up filter, and (b) a front Teflon filter and a quartz back-up filter. The determination of the $\mathrm{OC}$ concentrations in these filters allows for the calculation of the OC artifact (McDow and Huntzicker, 1990; Appel et al., 1983). Positive and negative sampling artifacts were quantified by numerous studies, for sites around the world, Table 4. The positive sampling artifacts ranged roughly between 10 and $50 \%$ of OC, 10 in the vast majority of studies. Conversely, negative artifacts were addressed by a very limited number of studies, which concluded that they may account for $5-6$ or up to $50 \%$ of the OC.

Sampling trains such as the one described by Cheng Y. et al. (2012) could be interesting for routine monitoring in networks, as the nitrate and OC can be measured 15 by a single sampling channel if appropriate back-up sorbents are implemented. However, the accurate quantification of negative artifacts still remains a challenge. Chow et al. (2010) concluded that there is no simple way to correct for sampling artifacts using current measurements. In the US STN/CSN it is recommended to collect field blanks and back-up filters at the same frequency and passive deposit duration (e.g., once per month on an every-sixth-day sampling schedule; expose field blanks for a minimum of three days, Watson et al., 2007). Also Maimone et al. (2011) suggest, for relatively accurate, simple, and cost-effective artifact OC estimation in large networks, back-up filter sampling on at least $10 \%$ of the sampling days at all sites with artifact correction on a sample-by-sample basis.

25 A number of authors suggest that further research is necessary on: sample duration for filter saturation of adsorbed gases; dependence of adsorbed gas saturation on particle composition, temperature, relative humidity, and sampling face velocity; evaporation rates of semi-volatile organic compounds during sampling; and source-specific tests (e.g., diesel, gasoline, and wood smoke) (Chow et al., 2010). More attention should be

\section{AMTD}

8, 9649-9712, 2015

Measurement of elemental carbon (EC) and organic carbon (OC)

A. Karanasiou et al.

\section{Title Page}

Abstract Introduction

Conclusions References

Tables Figures

14

4

Back

Printer-friendly Version

Interactive Discussion 
paid to semivolatile $\mathrm{OC}$ in the future, considering its secondary nature (Eatough et al., 2006; Modey et al., 2004), and its influence on regional haze (Long et al., 2005). The impact of OC negative sampling artifacts is still under-studied, especially in Europe, and remains a challenge.

\section{3.3 Interference from other aerosol components}

\subsubsection{Carbonate carbon (CC)}

The non-quantification of existing CC may significantly bias thermal OC and EC determination especially in certain areas (sites affected by construction works or resuspended road dust), and/or under specific meteorological conditions e.g., during desert 10 dust intrusions. The decomposition temperature of carbonate may vary depending on a number of factors such as: the chemical composition of the carbonate compound (e.g., $\mathrm{CaCO}_{3}$ vs. $\left.\mathrm{CaMg}\left(\mathrm{CO}_{3}\right)_{2}\right)$, the presence of other minerals (hematite), the crystal form (e.g. calcite vs. aragonite), the grain size and the temperature protocol used (Karanasiou et al., 2011). CC was reported to evolve during the maximum temperature 15 step in He, i.e., between 700 and $850^{\circ} \mathrm{C}$ (Karanasiou et al., 2011; Miyazaki et al., 2007; Birch and Cary, 1996) for a NIOSH-type protocol. Cavalli et al. (2010) demonstrated that natural calcite decomposes at $650^{\circ} \mathrm{C}$ in the inert mode of the EUSAAR_2 protocol. When laboratory-grade calcium carbonate powder was analyzed by the IMPROVE protocol the evolved $\mathrm{CO}_{2}$ was detected at the $550^{\circ} \mathrm{C}$ set point (Chow et al., 2001).

20 However, evolution temperatures may vary substantially depending on the mixture of $\mathrm{CC}$ with other materials; e.g., the presence of $\mathrm{NaCl}$ decreases the decomposition temperature of dolomite from 735 to $560^{\circ} \mathrm{C}$ when pure dolomite was analysed by thermal analysis (Webb and Kruger, 1970).

The NIOSH 5040 method recommends fumigation of the aerosol samples with $\mathrm{HCl}$

prior to thermal-optical analysis to eliminate any interference of CC. However, fumigation with $\mathrm{HCl}$ causes losses of organic compounds like organic acids, induces intense charring phenomena and causes oven damage (Karanasiou et al., 2011; Cavalli et al.,

AMTD

8, 9649-9712, 2015

Measurement of elemental carbon (EC) and organic carbon (OC)

A. Karanasiou et al.

Title Page

Abstract Introduction

Conclusions References

Tables Figures

14 4

Back

Full Screen / Esc

Printer-friendly Version

Interactive Discussion

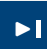

Close 
2010). To calculate CC concentrations some researchers suggest manual integration of the sharp peak (if present) appearing in the last step of the inert mode of a NIOSH-like protocol (Miyazaki et al., 2007; Xu et al., 2004; Schauer et al., 2003; Birch and Cary, 1996; CEN/TR 16243, 2011). Jankowski et al. (2008) suggested a thermal treatment of 5 aerosol loaded filters at $460^{\circ} \mathrm{C}$ for $60 \mathrm{~min}$ in an $\mathrm{O}_{2}$ atmosphere to remove $\mathrm{OC}$ and $\mathrm{EC}$, and a subsequent determination of TC, which would be completely attributed to CC. Cavalli et al. (2010) also suggested a separate analysis for CC measurements, like the direct determination of the amount of $\mathrm{CO}_{2}$ produced by acidifying the sample. Perrone et al. (2011) and Cuccia et al. (2011) used acid pretreatment and infrared spectroscopy 10 measurements to identify CC presence in the sample and fitted a Gaussian function to the FID signal to determine CC, EC, and OC levels. Karanasiou et al. (2011) compared the $\mathrm{HCl}$ acidification method, the manual integration of the sharp peak appearing in the last step of the inert mode of a NIOSH-like protocol, and the acidification of the sample with phosphoric acid. The peak integration method provided higher CC concentrations 15 than the acidification method (Karanasiou et al., 2011), and therefore the determination of CC with an independent method (e.g., by acidic decomposition of $\mathrm{CO}_{3}^{2-}$ and subsequent detection of $\mathrm{CO}_{2}$ ) is recommended when other sample aliquots are available.

However, the overestimation of $\mathrm{OC}$ or $\mathrm{EC}$ due to $\mathrm{CC}$ interference might be negligible for fine particulate matter, since the contribution of $\mathrm{CC}$ in $\mathrm{PM}_{2.5}$ is usually below $5 \%$ of 20 TC (Karanasiou et al., 2011; Querol et.al, 2004; Chow and Watson, 2002), but it could be significant if $\mathrm{CC}$ evolves with $\mathrm{EC}$ and for $\mathrm{PM}_{10}$ or coarse $\mathrm{PM}$ fractions.

\subsubsection{Metal oxides}

The presence of certain minerals in aerosol samples can complicate the optical correction for pyrolysis. Chow et al. (2001) and Fung et al. (2002) report that mineral 25 oxides, like iron oxide might provide oxygen and oxidize some EC at high inert-mode temperatures. Mixtures of these minerals with carbonate such as calcite-hematite can decrease the decomposition temperature of pure calcite by $15^{\circ} \mathrm{C}$ (Robles et al., 2011). For samples which contain large fractions of resuspended soil, demolition dust, desert

\section{AMTD}

8, 9649-9712, 2015

Measurement of elemental carbon (EC) and organic carbon (OC)

A. Karanasiou et al.

\section{Title Page}

Abstract

Conclusions

Tables

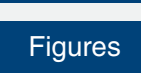

14

4

Back

Introduction

References

Figures

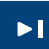

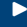

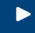

Close

Printer-friendly Version

Interactive Discussion 
dust or sites close to railways, trams and subways where a high content of Fe oxides is expected the split between OC and EC should be examined carefully (Chow et al., 2004; Querol et al., 2012).

\subsubsection{Inorganic salts}

5 The presence of certain elements ( $\mathrm{Na}, \mathrm{K}, \mathrm{Pb}, \mathrm{Mn}, \mathrm{V}, \mathrm{Cu}, \mathrm{Ni}, \mathrm{Co}$, and $\mathrm{Cr}$ ), existing either as contaminants on the filters, or as part of the deposit material, has been shown to catalyze the removal of EC at lower temperatures (Lin and Friedlander, 1988). Such catalysis would affect the distribution of carbon peaks during the analysis.

In the study of Wang et al. (2010) metal salt particles generated in the laboratory, in10 cluding alkali $\left(\mathrm{NaCl}, \mathrm{KCl}, \mathrm{Na}_{2} \mathrm{SO}_{4}\right)$, alkaline-earth $\left(\mathrm{MgCl}_{2}, \mathrm{CaCl}_{2}\right)$ and transition metal salts $\left(\mathrm{CuCl}_{2}, \mathrm{FeCl}_{2}, \mathrm{FeCl}_{3}, \mathrm{CuCl}, \mathrm{ZnCl}_{2}, \mathrm{MnCl}_{2}, \mathrm{CuSO}_{4}, \mathrm{Fe}_{2}\left(\mathrm{SO}_{4}\right)_{3}\right)$, were deposited on a layer of diesel particles to investigate their effect on $\mathrm{EC}$ and $\mathrm{OC}$ quantification with thermal-optical analysis using the NIOSH5040 protocol and the Sunset analyzer. The measurements showed that metal salts lowered the split time, reduced the oxidation temperature of EC and enhanced charring. The split point was more dependent on changes in EC oxidation temperature than it was on charring. The resulting EC/OC ratio was reduced by $0-80 \%$ in the presence of most of the salts. Transition metals were more active than alkali and alkaline-earth metals; copper was the most active. Copper and iron chlorides were more active than sulfates. The melting point of metal salts was strongly correlated with the increase of OC charring, but not with the reduction of EC oxidation temperature. Hitzenberger et al. (2011) analysed mixtures of industrial carbon black (Elftex) and $\mathrm{NaCl}$ by thermal-optical analysis and concluded that $\mathrm{Na}$ lowers the combustion temperature of EC from 870 to approximately $800^{\circ} \mathrm{C}$. An older study by Novakov and Corrigan (1995) reported that high concentrations of the ions $\mathrm{Na}^{+}$and $\mathrm{K}^{+}$ 25 in biomass burning aerosol samples catalyze the combustion of EC material at lower temperatures.

Inorganic constituents that coexist with carbonaceous materials in ambient aerosol samples such as $\left(\mathrm{NH}_{4}\right)_{2} \mathrm{SO}_{4}$ and $\mathrm{NH}_{4} \mathrm{HSO}_{4}$ can enhance charring of insoluble $\mathrm{OC}(\mathrm{Yu}$

\section{0}

AMTD

8, 9649-9712, 2015

Measurement of elemental carbon (EC) and organic carbon (OC)

A. Karanasiou et al.

Title Page

Abstract Introduction

Conclusions References

Tables Figures

14 4

Back

Full Screen / Esc

Printer-friendly Version

Interactive Discussion

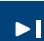

lose 
et al., 2002). Moreover, the presence of oxygen in $\left(\mathrm{NH}_{4}\right)_{2} \mathrm{SO}_{4}$ could falsify the $\mathrm{OC}$ and EC concentrations (if charring correction is wrong) by releasing oxygen in the pure $\mathrm{He}$ mode and therefore allowing some of the EC to evolve in the inert mode (Hitzenberger et al., 2011).

\section{3.3.4 Brown carbon}

Light-absorbing organic matter in atmospheric aerosols of various origins, e.g., soil humic acids, humic-like substances (HULIS), tarry materials from combustion, bioaerosols, biomass burning aerosols often referred to as "Brown carbon", BrC also interferes in thermal-optical analysis (Saleh et al., 2013; Andreae and Gelencser, 2006).

10 The light absorption coefficient of these substances increases strongly from long to short wavelengths, resulting in their brown appearance. The presence of significant concentrations of $\mathrm{BrC}$ in atmospheric aerosol may cause substantial bias resulting in erroneous $\mathrm{OC}$ and EC concentration values. Indeed, BrC can affect the laser correction, causing changes in reflectance or transmittance as these compounds are re5 moved.

The spectral absorption of $\mathrm{BrC}$ differs from that of EC. At the red wavelength of the HeNe laser used in thermal-optical instruments (DRI analyzer, Sunset analyzer), BrC absorbs much less than $\mathrm{EC}$, so that the $\mathrm{BrC}$ fraction impacts the determination at this wavelength less than at potential lower wavelengths (Chen et al., 2015). BrC is prone 20 to charring during the analysis and, as a result, the instrument will interpret the fraction of $\mathrm{BrC}$ combusted before the split point as $\mathrm{OC}$, and the more refractory part of $\mathrm{BrC}$ will be wrongly attributed to $\mathrm{EC}$, given the limitations of the charring optical correction. Monitoring the transmittance or reflectance at multiple wavelengths, analyzing the time evolution of charring and the comparison of different determined split time values 25 may allow a more accurate separation of the EC contained in the sample and the PC generated during the analysis (Chen et al., 2015).

Reisinger et al. (2008) reported that the discrepancy in EC values between different thermal protocols is linked to the percentage of $\mathrm{BrC}$ in total LAC. Another effect of $\mathrm{BrC}$
AMTD

8, 9649-9712, 2015

Measurement of elemental carbon (EC) and organic carbon (OC)

A. Karanasiou et al.

\section{Title Page}

Abstract Introduction

Conclusions References

Tables Figures

14

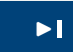

4

Back

Full Screen / Esc

Printer-friendly Version

Interactive Discussion 
is that compounds from this family can increase substantially PC generated during the analysis. This can erroneously be classified as EC and therefore lead to an overestimation of EC and underestimation of OC (Hitzenberger et al., 2011) if charring is not correctly accounted for. A NIOSH-like protocol with transmittance correction attributes 5 more of the char and the $\mathrm{BrC}$ to OC than IMPROVE-TOR does, which may attribute these components more to EC (Soto-Garcia et al., 2011).

\section{Reference materials for OC and EC determination by thermal-optical analysis}

In May 2000, the Steering Committee for Black Carbon Reference Materials (http://www.geo.uzh.ch/en/units/physische-geographie-boden-biogeographie/ 10 services/black-carbon-reference-materials) defined reference materials for $\mathrm{BC}$ as those being: (1) generally available, (2) homogeneous, (3) stable over a long period of time, (4) inexpensive to obtain, and (5) representing natural samples. As discussed by Baumgardner et al. (2012) and Chai et al. (2012), at present there are no materials that have been shown to meet either these nor the ISO or NIST definitions for 15 reference material $(\mathrm{RM})$ or certified reference material (CRM), for soot properties. There are, however, numerous techniques for producing soot particles that might meet the requirements for a standard reference material (SRM). Some of these techniques use methods to continuously produce soot particles while other methods fabricate soot particles, put them in a liquid suspension and bottled them for application on

filers or nebulization (Baumgardner et al., 2012). Many of these types of particles are not soot, because they are not produced from combustion; however, they have some characteristics of soot that can be used to test a sensor in an instrument.

A number of potential SRM candidates for thermal-optical analysis, TOA have been introduced in recent years (Iskandar et al., 2001; Lee et al., 2007; Master, 1991; Yang and Yu, 2002; Chen et al., 2004; Klouda et al., 2005); however, none have been accepted as a standard. For example, a filter-based NIST standard, reference material 8785 , was developed with the intent of calibrating TOA methods. This RM was pro-

\section{AMTD}

8, 9649-9712, 2015

Measurement of elemental carbon (EC) and organic carbon (OC)

A. Karanasiou et al.

Title Page

Abstract Introduction

Conclusions References

Tables Figures

14

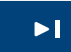

4

Back

Full Screen / Esc

Printer-friendly Version

Interactive Discussion 
duced by resuspending urban dust (NIST standard 1649a) and collecting the sample on quartz fibre filters (Klouda et al., 2005). The results for TC agreed quite well with the reference material, but the measured fraction of OC differed by more than $60 \%$ (Klouda et al., 2005). Another material tested, in this case for soot, is diffusion flame 5 soot (Kirchstetter and Novakov, 2007; Stipte et al., 2005) produced by burning methane in an inverted fiow reactor (CAST soot generator, http://www.sootgenerator.com/). Another source of reference particles is the Palas GFG spark discharge aerosol generator (Roth et al., 2004). It produces a constant, reproducible particle size and concentration and has been widely used for studies of soot microstructure, composition, reactivity 10 and oxidation, although it is not a combustion aerosol. It is used, in context with the comparison to an inert graphitic soot, to represent the full range of oxidative reactivity (Schmid et al., 2011). Also, NIST has issued the world's first RM for single-wall carbon nano-tube soot, and the performance of single-wall carbon nano-tube analysis by TOA techniques has already been tested (John et al., 2012).

15 A recent development (Popovicheva et al., 2011) is the creation of tailored soot whereby graphitized thermal soot is precisely coated with a known amount of organics, aimed at representing atmospheric EC and OC. With this approach, the EC/OC ratio was expected to be controlled such that TOA techniques would be evaluated. It should be noted, however, that one requirement for reference materials is that they are representative of the parameter they intend to provide a reference for, and in the case of $O C$ and EC this implies that the EC and the OC/EC ratio of such a material should resemble the EC and the OC/EC ratio of ambient aerosol, as should its refractivity. These tailored materials do not yet meet this requirement because the EC in these materials evolves at a much higher temperature $\left(>800^{\circ} \mathrm{C}\right)$ than ambient EC. Also the organic coatings tested so far do not resemble ambient aerosols (the coatings were initially selected to show minimum charring). Finally, Chai et al. (2012) describe a relatively simple approach for collection of a matched OC-EC filter set, based on aerosolization of an aqueous OC solution and EC suspension, to be used in inter-comparison and round robin tests.

\section{AMTD}

8, 9649-9712, 2015

Measurement of elemental carbon (EC) and organic carbon (OC)

A. Karanasiou et al.

Title Page

Abstract Introduction

Conclusions References

Tables Figures

14

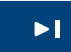

4

Back

Printer-friendly Version

Interactive Discussion 
One final limitation is the analytical procedure: any of the candidate RMs must be homogeneously deposited on clean filters with a well-known mass within the appropriate concentration range for each instrument to avoid saturation, to facilitate quantification of $\mathrm{OC}$ and EC and thus calibrate the separation between OC and EC. It is important 5 that the method of application, i.e., how the RM is introduced to the measurement system, does not affect the response of the TOA to the SRM and that the method of application is a part of the SRM protocol. In addition, if the EC/OC fraction is to be determined, then this parameter must be fully characterized for the selected SRM and remain constant with time.

10 In sum, several materials have been tested in the past, although none have yet fulfilled the criteria to be considered eligible reference materials for soot or for $\mathrm{OC}$ and EC by TOA techniques.

\section{Intercomparison of thermal-optical analysis methods}

Various methods and laboratories usually agree well on the TC content, but large dis15 crepancies have been found for the OC and EC concentrations (e.g.: Reisinger et al., 2008; Sciare et al., 2008; Maenhaut et al., 2009). These discrepancies are relatively more pronounced for EC due to its lower concentrations compared to OC. The differences observed among various methods are mostly reported as differences in EC concentrations and/or EC/TC ratios. As the thermal-optical methods mainly differ in 20 the temperature protocol and charring correction approach we focus on $\mathrm{NIOSH}$-like, IMPROVE_A and EUSAAR_2 protocols and on transmittance vs. reflectance based correction for charring.

\subsection{Comparison of TOT and TOR}

Many studies have investigated the effect of the optical correction on the $\mathrm{OC}$ and

EC concentrations and they have all concluded that the EC values determined us-
AMTD

8, 9649-9712, 2015

Measurement of elemental carbon

(EC) and organic carbon (OC)

A. Karanasiou et al.

Title Page

Abstract

Conclusions

Tables ces

\section{Figures}

14

4

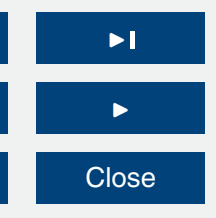

Full Screen / Esc

Printer-friendly Version

Interactive Discussion 
ing a thermal-optical transmittance (TOT) method are 30-70\% lower than those determined using a thermal-optical reflectance (TOR) method (Chow et al., 2001, 2004, 2009; Subramanian et al., 2006; Cheng et al., 2010, 2011; Soto-Garcia et al., 2011; Maenhaut et al., 2012; Chiappini et al., 2014) adsorbed througout the filter.

5 Table 5 provides the slope of the linear regression between EC concentrations determined using TOR and those using TOT when the same protocol is used.

Most studies found a slope of $\sim 2$ when they compared TOR EC with TOT EC using the IMPROVE (Chow et al., 2001; Subramanian et al., 2006) and IMPROVE_A (Cheng et al., 2010, 2011; Soto-Garcia et al., 2011) protocols. Chow et al. (2009) found a lower 10 slope (1.2) with the IMPROVE protocol, and Wu et al. (2012) found larger differences (slope up to 3.4) using both IMPROVE_A and ACE-Asia protocols for urban samples in China.

Chow et al. (2004) compared the EC obtained from TOR and TOT with 2 temperature protocols, namely highT protocol with Tmax at $900^{\circ} \mathrm{C}$ and LowT protocol with Tmax 15 set at $550^{\circ} \mathrm{C}$. On average, TOT resulted in $\sim 30 \%$ lower EC than TOR for the LowT protocol and $\sim 70 \%$ lower EC for the HighT protocol. The same was also shown by comparing TOT EC and TOR EC using both EUSAAR_2 and NIOSH-900 protocols (Maenhaut et al., 2012). The difference between TOR EC and TOT EC was smaller for EUSAAR_2.

20 Chiappini et al. (2014) observed the largest differences between the TOT and TOR results for rural samples using the NIOSH-850 protocol (slope $=2.1$ ). These differences may be explained by the aerosol chemical composition or its mixing state, which can be rather different between urban and rural sites as the latter ones could be much more influenced by light-absorbing organic material (e.g.: particles emitted by biomass burning processes).

The reason for the difference between TOT and TOR has been further investigated by examining charring of the filter backside and microscopic cross sections of a filter punch at different parts of the temperature cycle during the thermal analysis. It appeared that reflectance was dominated by charring of $\mathrm{OC}$ that co-existed with $\mathrm{EC}$ on

\section{AMTD}

8, 9649-9712, 2015

Measurement of elemental carbon (EC) and organic carbon (OC)

A. Karanasiou et al.

\section{Title Page}

Abstract Introduction

Conclusions References

Tables Figures

\section{4}

4

Back

Printer-friendly Version

Interactive Discussion 
the surface of the filter, while transmittance was dominated by the charring of organic vapours distributed throughout the filter. When oxygen was added to the analysis, the surface original EC and PC evolved before the charred $O C$ that was distributed throughout the filter. Hence, transmittance achieved its initial value later than reflectance (Chow 5 et al., 2004). Using a radiative transfer model, Chen et al. (2004) showed that this explanation is plausible, and that simultaneous reflectance and transmittance measurements can be used to estimate contributions to charring from the surface particulate $\mathrm{OC}$ and the charred vapours adsorbed throughout the filter.

\subsection{Comparison of IMPROVE, NIOSH-like and EUSAAR_2 protocols}

10 Table 6 summarizes the studies conducted on the comparison of thermal protocols and provides information on the test samples, analyzer used, optical correction method, protocols compared and the slope of the linear regression between the EC values obtained with two different protocols.

In the study of Chow et al. (2001) the NIOSH-850 EC was typically less than half 15 of the IMPROVE EC. The difference was significantly higher for some specific source samples, such as cooking emission samples. By studying the increase of the light transmission and reflectance in the $\mathrm{NIOSH}$ protocol during the last temperature step in the $\mathrm{He}$ mode they concluded that the carbon fraction evolving at $850^{\circ} \mathrm{C}$ in the He mode should be classified as EC rather than OC. When this portion of $\mathrm{NIOSH} \mathrm{OC}$ was added to the NIOSH EC, the IMPROVE and NIOSH analyses were in good agreement.

Schauer et al. (2003) compared four thermal protocols that had the same temperature program in the oxidizing mode but different temperature steps and peak temperature in the inert mode. They tested the ACE-Asia, a NIOSH-like protocol with Tmax at $870^{\circ} \mathrm{C}$ and the protocols He-750, He-650 and He-550 with Tmax equal to 750, 650, and $550{ }^{\circ} \mathrm{C}$, respectively, with the latter being similar to the IMPROVE protocol. Light transmittance was used for charring correction. They concluded that He-550 EC is about 1.5 times higher than NIOSH-like EC for urban samples. The same slope $(\sim 1.5)$ was observed in the study of Subramanian et al. (2006) again for urban samples.

\section{AMTD}

8, 9649-9712, 2015

Measurement of elemental carbon (EC) and organic carbon (OC)

A. Karanasiou et al.

\section{Title Page}

Abstract Introduction

Conclusions References

Tables Figures

14 4 Back $\rightarrow 1$ $>$ (lose Close

Printer-friendly Version

Interactive Discussion 
Many other studies report slopes in the range 1.2-2 when they compared a protocol with a low peak inert temperature $\left(550-580^{\circ} \mathrm{C}\right)$ like IMPROVE or IMPROVE_A with a NIOSH-like protocol with the peak inert temperature at $800-900^{\circ} \mathrm{C}$ (Sciare et al., 2008; Reisinger et al., 2008; Chow et al., 2009; Maenhaut et al., 2009; Cheng et al., 5 2010, 2012, 2014; Piazzalunga et al., 2011; Zhi et al., 2011; Khan et al., 2012).

Only one study, Sharma et al. (2002) contradicts the general conclusion that IMPROVE EC is higher than the NIOSH EC. In that study, urban, suburban, rural and remote samples were tested and the NIOSH-like EC (TOT) was found to be slightly higher than the IMPROVE EC (TOR) (slope $=0.92$ ).

10 The EUSAAR_2 protocol was more recently developed, with consequently fewer comparison studies. Maenhaut et al. (2012) compared EUSAAR_2 with a NIOSH-900 protocol (with the peak inert temperature set at $900^{\circ} \mathrm{C}$ ) against a batch of $70 \mathrm{PM}_{10}$ samples collected at various sites in Belgium. A very good agreement was observed for TC (slope $\left.=1.02, R^{2}=0.99\right)$. However, the slope between EUSAAR_2 EC and NIOSH 15 EC when transmittance correction was used was $1.3\left(R^{2}=0.96\right)$. When reflectance was used the slope was equal to 1.1 with $R^{2}=0.95$ (Maenhaut et al., 2012).

Cheng et al. (2014) concluded that the OC and EC results were more equivalent between IMPROVE_A and EUSAAR_2 than between IMPROVE_A and NIOSH-870. EC IMPROVE_A vs. EC EUSAAR_2 had a slope of 0.9. Similarly a study conducted 1.1 while the slope between EC EUSAAR_2 and EC NIOSH-870 was 1.5 (Piazzalunga et al., 2011) consistent with the results of Schauer et al. (2003) when comparing a protocol with Tmax at $650^{\circ} \mathrm{C}$ as in EUSAAR_2 and the ACE-Asia protocol.

The differences between thermal optical methods are higher when different optical correction methods are compared simultaneously; e.g., Chow et al. (2001, 2004), SotoGarcia et al. (2011) and Cheng W. et al. (2012) observed that the IMPROVE EC (TOR) is higher than the NIOSH EC (TOT) (slope > 2.0). Wu et al. (2012) found that EC concentrations by the IMPROVE TOR method were on average 5.4 times higher than those by the ACE-Asia TOT protocol using the Sunset analyzer. The inconsistency in EC val-
AMTD

8, 9649-9712, 2015

Measurement of elemental carbon (EC) and organic carbon (OC)

A. Karanasiou et al.

\section{Title Page}

Abstract Introduction

Conclusions References

Tables Figures

14

4

Back

Printer-friendly Version

Interactive Discussion 
ues by the two protocols was found to be more prominent in samples that produced more charring during the analysis, such as samples influenced by wood burning.

Nevertheless, no equivalence or correlation between the different thermal-optical protocols can be expected taking into account the variance in OC/EC composition 5 and the influence of various salts, metals and metal oxides on the OC/EC split point. The general conclusion from the inter-comparison of thermal-optical protocols is that the identification of the "best" method is not possible so far. However it is evident that protocols with a rather low peak temperature in the inert mode like EUSAAR_2 and IMPROVE_A generally classify more carbon as EC compared to NIOSH-like protocols. 10 OC and EC concentrations are more equivalent between IMPROVE_A and EUSAAR_2 than between IMPROVE_A and NIOSH protocols. This difference seems to be reduced when reflectance monitoring is used for charring correction. Moreover, the comparability of various methods also depends on the composition of the aerosol samples: samples highly influenced by biomass burning emissions display higher discrepancies 15 when analyzed by different protocols.

\section{Inter-laboratory comparison studies}

Several inter-laboratory comparisons have been carried out over the years with the objective to evaluate the comparability of the results produced by the participants. Many studies include comparisons of laboratories using different methods, even with and

\section{without optical correction for charring, hence making dificult the identification of the} variation due to the method and that due to the laboratories themselves. Different intercomparison studies analyze and report the results in a different manner. As for the parameters reported, most of the studies report the TC, EC and OC filter loadings in $\mu \mathrm{g} \mathrm{cm}^{-2}$, others do so in equivalent ambient concentrations in $\mathrm{g} \mathrm{m}^{-3}$, and others report 25 the EC/TC ratio together with the TC loadings in $\mathrm{g} \mathrm{cm}^{-2}$.

The agreement between laboratories was relatively poor when only thermal methods were used, and it improved when optical correction was applied (Birch, 1998; Schmid
Measurement of elemental carbon (EC) and organic carbon (OC)

A. Karanasiou et al.

Title Page

Abstract Introduction

Conclusions References

Tables

Figures

14

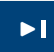

4

Back

Printer-friendly Version

Interactive Discussion 
et al., 2001; EUSAAR, 2011). EC concentrations determined with a method without optical correction were overestimated compared to IMPROVE_A and EUSAAR_2 results (EUSAAR, 2011).

Table 7 shows the inter-laboratory studies using thermal-optical methods. Results 5 are given as relative standard deviation of $\mathrm{EC}, \mathrm{OC}$ and TC concentrations including, when available, the range of concentrations tested. When the relative standard deviation was not reported, and could not be calculated from the reported data, other statistics have been reported, such as the reproducibility. As for the intercomparison of thermal-optical methods, most of these studies have been conducted without any 10 calibration of the temperature probe, which could partly be responsible for the discrepancies listed below.

Birch (1998) reported relative standard deviation for OC of 3 to 7 , and 6 to $26 \%$ for EC between 5 laboratories using a TOT method for a subset of 5 samples, and after excluding a sixth laboratory leading to a relative standard deviation for EC of $144 \%$.

15 Schmid et al. (2001) reported relative standard deviation for TC from 6 to 7, and 26 to $48 \%$ for EC concentrations for 5 laboratories.

An inter-laboratory comparison in which all the 3 participants used the NIOSH5040 method to analyze 50 samples showed relative standard deviations of 6, 12 and $10 \%$ for TC, OC and EC, respectively (Birch et al., 1999; Birch, 2002).

Schauer et al. (2003) reported results from an inter-comparison of 8 different laboratories, all of them using a protocol similar to ACE-Asia, and used transmittance as a correction. The participants calibrated and operated their instruments following $\mathrm{NIOSH}$ guidelines. The ambient PM samples (including blanks) covered a wide range of concentrations, 0.4 to $25 \mathrm{\mu g} \mathrm{cm}^{-2}$ of OC and 0.04 to $8.4 \mu \mathrm{g} \mathrm{cm}^{-2}$ of EC. The relative standard deviation (excluding blanks) was 4 to $13 \%$ for OC and 13 to $21 \%$ for EC.

Chai et al. (2012) assessed the results of an inter-laboratory comparison with 7 participants using $\mathrm{NIOSH}$-like protocols. The exact protocols were slightly different for different laboratories. Four sets of 10 to 12 filter samples were analyzed, which were considered to be equivalent and therefore reported together. Each laboratory an-

\section{AMTD}

8, 9649-9712, 2015

Measurement of elemental carbon (EC) and organic carbon (OC)

A. Karanasiou et al.

\section{Title Page}

Abstract Introduction

Conclusions References

Tables Figures

14 4

Back

Printer-friendly Version

Interactive Discussion 
alyzed between 2 and 12 punches of each set. The concentrations ranged between 8 to $14 \mathrm{\mu g} \mathrm{cm}^{-2}$ for EC, 10 to $17 \mathrm{\mu g} \mathrm{cm}^{-2}$ for OC, and 20 to $27 \mu \mathrm{g} \mathrm{cm}^{-2}$ for TC. The relative standard deviations were 7 to 9,7 to 10 , and 5 to $9 \%$ for EC, OC, and TC, respectively.

Several inter-laboratory comparisons were carried out in the framework of the EU5 SAAR project. Different protocols were used by the participating laboratories: $\mathrm{NIOSH}$, quartz, EUSAAR_1, EUSAAR_2, IMPROVE, and some customized protocols. The relative standard deviation for TC among the participating laboratories was $11 \%$, 17-20, 9 and 10\% for four different exercises (EUSAAR, 2007, 2008, 2010 and 2011). However, unacceptable differences were observed for samples with particu10 larly low TC $\left(<5 \mu \mathrm{g} \mathrm{cm}^{-2}\right)$ (EUSAAR, 2007), or even for samples with high TC content $\left(>10 \mathrm{~g} \mathrm{~cm}^{-2}\right)$ (EUSAAR, 2010). The variation for the EC concentrations was much higher (40 or $25 \%$ including all laboratories and methods) (EUSAAR, 2007 and 2011), and it was protocol-dependent. The relative standard deviation was $29 \%$ for laboratories using NIOSH or quartz protocols (EUSAAR, 2007) and $48 \%$ for laboratories using 5 the NIOSH protocol (EUSAAR, 2008), with differences up to a factor of 14 between two participants (EUSAAR, 2010), whereas it was reduced to $13 \%$ for 2 laboratories using the EUSAAR_1 protocol (EUSAAR, 2007), and 30-36\% or $20 \%$ for laboratories using the EUSAAR_2 protocol after removing the outliers (EUSAAR, 2008 and 2010). The differences among laboratories were found to be higher for the lowest loaded filters 20 (EUSAAR, 2011).

An intercomparison study based on the reference material NIST 8785 with 12 laboratories using the EUSAAR_2 protocol found a relative standard deviation of the EC/TC ratio of $17 \%$ (EUSAAR, 2009).

The differences in the EC/TC ratios were systematic and laboratory-dependent, i.e., each laboratory deviated from the average EC/TC ratio similarly for the different intercomparison exercises (EUSAAR, 2008, 2009 and 2010). The discrepancies may be related to the correction of the laser drift with temperature and/or to the inaccuracy of the temperature experienced by the filter with respect to the set temperature in the He-mode.

\section{AMTD}

8, 9649-9712, 2015

Measurement of elemental carbon (EC) and organic carbon (OC)

A. Karanasiou et al.

Title Page

Abstract Introduction

Conclusions References

Tables Figures

14 4 Back

Printer-friendly Version

Interactive Discussion 
An inter-laboratory comparison performed within the ACTRIS project with 18 participants applying thermal or thermal-optical methods (NIOSH-like or EUSAAR_2) to ambient PM samples reported reproducibility relative standard deviations from 13 to $27 \%$ (ACTRIS, 2011) and 9 to $23 \%$ when only laboratories using the EUSAAR_2 protocol 5 were assessed. For the EC/TC ratio, the reproducibility relative standard deviations ranged from 12 to $33 \%$, including all the optical correction methods, and 10 to $29 \%$ when only laboratories using the EUSAAR_2 protocol were assessed, after excluding one sample with EC/TC ratio below 0.05 .

Two inter-laboratory comparison exercises were carried out between European 10 Union National Reference Laboratories for air quality or delegated organizations, organized by JRC-IES European Reference Laboratory for Air Pollution (ERLAP). All the participants used the Sunset analyzer and used either NIOSH or EUSAAR_2 protocols. The first exercise (Emblico et al., 2012) involved 16 participants (two of them using the field version of the instrument). The laboratories using field versions of the analyzer 15 gave results classified as outliers, in comparison with the rest of the values. Better reproducibility was found for TC (from 4 to $8 \%$ ) than for OC (5 to 12\%) and EC (10 to $25 \%$ ), and it was not shown to be protocol-dependent. The second exercise (Cavalli et al., 2012) involved 17 participants and reported reproducibility standard deviations for TC of 5 to $11 \%$. For the EC/TC ratio, the reproducibility standard deviations ranged

8 to $35 \%$ for the NIOSH-like protocol, and from 4 to $19 \%$, for the EUSAAR protocol. The poorer reproducibility found for the NIOSH users could be partly caused by the number of variations of the NIOSH protocol used in this exercise in comparison to the single version of the EUSAAR_2 protocol.

Chiappini et al. (2014) report the results of an intercomparison study between 5 25 laboratories. Four laboratories used the Sunset analyser with transmittance correction (three of them employed the EUSAAR_2 protocol and one the NIOSH5040 protocol) while one laboratory used the DRI analyser with both transmittance and reflectance correction and the IMPROVE protocol. While there was good agreement on TC measurements (relative standard deviation $<5 \%$ ) the repeatability relative standard devi-
AMTD

8, 9649-9712, 2015

Measurement of elemental carbon (EC) and organic carbon (OC)

A. Karanasiou et al.

\section{Title Page}

Abstract Introduction Conclusions References

Tables Figures

14 4 Back
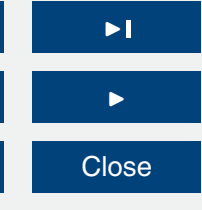

Full Screen / Esc

Printer-friendly Version

Interactive Discussion 
ations ranged from 1 to $17 \%$ for EC, and up to $9 \%$ for OC. The differences observed between the laboratories for a given protocol were attributed to the lack of temperature offset calibration by the time of the analyses.

The department of Air Quality of Public Health Service Amsterdam organized a com5 parison exercise with 17 participating laboratories using an identical instrument set-up to analyze 5 filter samples and 2 sucrose solutions with both the EUSAAR_2 and the $\mathrm{NIOSH}-870$ protocols. For the first time, a correction for temperature offsets was applied. Excluding 2 laboratories, the reproducibility relative standard deviations for TC were $15 \%$ for EUSAAR_2 and $12 \%$ for NIOSH-870; and for EC they were $20 \%$ for EU10 SAAR_2 and $26 \%$ for NIOSH-870. Poor performance or deviating results were shown not to be protocol-dependent. The analysis of sucrose solutions were used to identify wrong TC calibrations and deviating performance. The repeatability degree derived from analysis of known volume of sucrose solution depends on the analyst's performance, while it does not depend on the protocol used (Panteliadis et al., 2013 and 15 2015).

In sum, the inter-laboratory comparisons are better when all the laboratories use the same optical correction (either transmittance or reflectance) as opposed to mixed comparisons where different laboratories employ different corrections. The relative standard deviation for $\mathrm{TC}$ is lower than that for $\mathrm{EC}, \mathrm{OC}$ or EC/TC regardless of the protocol used.

20 The variations in the EC/TC ratios are often systematic and laboratory-dependent. The results from field instruments used off-line were difficult to assess, given that some studies showed a poor agreement between this type of instruments and the remainder of the participants, although some other studies showed a good agreement. The results of the intercomparisons did not improve over time, which implies the necessity of establishing a well-defined method to perform such measurements, including quality-control guidelines.

\section{AMTD}

8, 9649-9712, 2015

Measurement of elemental carbon (EC) and organic carbon (OC)

A. Karanasiou et al.

\section{Title Page}

Abstract Introduction

Conclusions References

Tables Figures

14

4

Back

Full Screen / Esc

Printer-friendly Version

Interactive Discussion 


\section{Conclusions}

The thermal-optical analysis is currently considered by the European Committee standardization body (CEN) as the reference methodology to quantify atmospheric particulate EC and OC deposited on filters. The most commonly used thermal protocols 5 include NIOSH-like, IMPROVE_A and EUSAAR_2 protocols either with transmittance or reflectance correction. The review of the literature pointed out that it is not possible to identify the "best" thermal-optical method.

- All thermal evolution protocols are comparable for TC concentrations but the results vary significantly concerning OC and especially EC concentrations, due to

- Thermal protocols with a rather low peak temperature in the inert mode like IMPROVE_A and EUSAAR_2 generally tend to classify more carbon as EC compared to NIOSH-like protocols.

- The comparability of the various protocols also depends on the composition of aerosol samples. Samples highly influenced by biomass burning emissions display higher discrepancies in $\mathrm{OC}$ and $\mathrm{EC}$ determination when analyzed by different protocols.

- Comparing the optical correction methods, the difference between reflectance and transmittance tends to be larger than the difference between different thermal protocols. In addition, the comparability of thermal protocols seems to improve when reflectance is used as a charring correction method.

- OC and EC results are more comparable between IMPROVE_A and EUSAAR_2 than between IMPROVE_A and NIOSH.

- CC interference might be negligible for fine aerosol, but it can be significant for coarse OC or EC concentrations. For samples containing large fractions of resus-
AMTD

8, 9649-9712, 2015

Measurement of elemental carbon (EC) and organic carbon (OC)

A. Karanasiou et al.

Title Page

Abstract Introduction

Conclusions References

Tables Figures

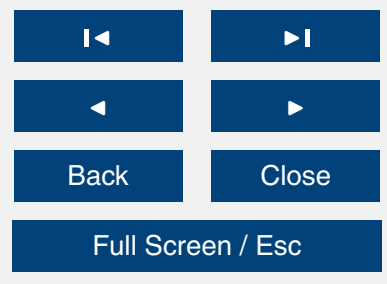

Printer-friendly Version

Interactive Discussion 
pended soil, demolition dust or African dust the interference from $\mathrm{CC}$ should be tested and the split between $\mathrm{OC}$ and EC should be examined carefully.

- The occurrence of brown carbon and other inorganic components such as oxides and salts in atmospheric aerosol samples may enhance charring and lead to erroneous determinations of $\mathrm{OC}$ and $\mathrm{EC}$.

- Positive sampling artifact due to the adsorption of gaseous organics onto the filter is likely to be significant at remote sites, consequently affecting the OC/EC ratio. The positive artifact could be reduced by using samplers with high face velocity or implementing denuders while the use of back-up filters can provide reasonable measurement of this positive artifact. However the use of denuders and back-up filters to quantify possible artifacts are not seen as suitable and necessary for routine network monitoring.

Acknowledgements. This work was undertaken under Mandate M/503 "Standardisation mandate to CEN, CENELEC and ETSI in support of the implementation of the Ambient Air Quality 15 Legislation", ENX "Ambient air - Measurement of airborne elemental carbon (EC) and organic carbon (OC) in $\mathrm{PM}_{2.5}$ deposited on filters". The authors would like to thank all members of Working Group WG 35 of CEN/TC 264 for their comments on the literature review.

\section{References}

ACTRIS: WP3-NA3: In-Situ Chemical, Physical and Optical Properties of Aerosols, Deliverable 20

$$
\text { D3.5, } 2011 .
$$

Andreae, M. O. and Gelencsér, A.: Black carbon or brown carbon? The nature of light-absorbing carbonaceous aerosols, Atmos. Chem. Phys., 6, 3131-3148, doi:10.5194/acp-6-3131-2006, 2006.

Appel, R. R., Tokiwa, Y., and Kothny, E. L.: Sampling of carbonaceous particles in the atmo25 sphere, Atmos. Environ., 17, 1787-1796, 1983.

Arp, H. P. H., Schwarzenbach, R. P., and Goss, K.-U.: Equilibrium sorption of gaseous organic chemicals to fiber filters used for aerosol studies, Atmos. Environ., 41, 8241-8252, 2007.

9684

\section{AMTD}

8, 9649-9712, 2015

Measurement of elemental carbon

(EC) and organic carbon (OC)

A. Karanasiou et al.

Title Page

Abstract

Introduction

Conclusions References

Tables

Figures

14

$>$ I

4

Back

$\checkmark$

Close

Full Screen / Esc

Printer-friendly Version

Interactive Discussion 
Bae, M. S., Schauer, J. J., DeMinter, J. T., Turner, J. R., Smith, D., and Cary, R. A.: Validation of a semi-continuous instrument for elemental carbon and organic carbon using a thermaloptical method, Atmos. Environ., 38, 2885-2893, 2004.

Baumgardner, D., Popovicheva, O., Allan, J., Bernardoni, V., Cao, J., Cavalli, F., Cozic, J., Diapouli, E., Eleftheriadis, K., Genberg, P. J., Gonzalez, C., Gysel, M., John, A., Kirchstetter, T. W., Kuhlbusch, T. A. J., Laborde, M., Lack, D., Müller, T., Niessner, R., Petzold, A., Piazzalunga, A., Putaud, J. P., Schwarz, J., Sheridan, P., Subramanian, R., Swietlicki, E., Valli, G., Vecchi, R., and Viana, M.: Soot reference materials for instrument calibration and intercomparisons: a workshop summary with recommendations, Atmos. Meas. Tech., 5, 1869-1887, doi:10.5194/amt-5-1869-2012, 2012.

Birch, M. E.: Analysis of carbonaceous aerosols: interlaboratory comparison, Analyst, 123, 851-857, 1998.

Birch, M. E.: Analytical instrument performance criteria: Occupational monitoring of particulate diesel exhaust by NIOSH method 5040, Appl. Occup. Environ. Hyg., 17, 400-405, 2002.

Birch, M. E. and Cary, R. A.: Elemental carbon-based method for monitoring occupational exposures to particulate diesel exhaust, Aerosol Sci. Tech., 25, 221-241, 1996.

Birch, M. E., Schlecht, P. C., and Epstein, P. S.: NIOSH 5050 - a rugged method for measuring occupational exposures to diesel particulate matter, American Industrial Hygiene Conference \& Exposition, 5 June 1999, Toronto, Canada, 1999.

20 Cavalli, F., Viana, M., Yttri, K. E., Genberg, J., and Putaud, J.-P.: Toward a standardised thermaloptical protocol for measuring atmospheric organic and elemental carbon: the EUSAAR protocol, Atmos. Meas. Tech., 3, 79-89, doi:10.5194/amt-3-79-2010, 2010.

Cavalli, F., Douglas, K., and Borowiak, A.: Results of the 2nd comparison exercise for EU National Air Quality Reference Laboratories (AQUILA) for TC, OC and EC measurements (2011), JRC Technical Reports, JRC70858, EUR 25304, ISBN 978-92-79-24756-9 (print), ISBN 978-92-79-24757-6 (pdf), ISSN 1018-5593 (print), ISSN 1831-9424 (online), Publications Office of the European Union, Luxembourg, 2012.

CEN/TR 16243: 2011 Ambient Air Quality - Guide For the Measurement of Elemental Carbon (EC) and Organic Carbon (OC) Deposited on Filters, CENFprCEN/TR 16243:2011, 29, 2011.

Chai, M., Birch, M. E., and Deye, G.: Organic and elemental carbon filter sets: preparation method and interlaboratory results, Ann. Occup. Hyg., 56, 959-967, 2012.
AMTD

8, 9649-9712, 2015

Measurement of elemental carbon

(EC) and organic carbon (OC)

A. Karanasiou et al.

Title Page

Abstract

Introduction

Conclusions References

Tables

Figures

14

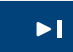

4

Back

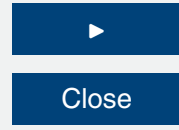

Full Screen / Esc

Printer-friendly Version

Interactive Discussion 
Chen, L.-W. A., Chow, J. C., Watson, J. G., Moosmüller, H., and Arnott, W. P.: Modeling reflectance and transmittance of quartz-fiber filter samples containing elemental carbon particles: implications for thermal/optical analysis, J. Aerosol Sci., 35, 765-780, 2004.

Chen, L.-W. A., Chow, J. C., Wang, X. L., Robles, J. A., Sumlin, B. J., Lowenthal, D. H., Zimmermann, R., and Watson, J. G.: Multi-wavelength optical measurement to enhance thermal/optical analysis for carbonaceous aerosol, Atmos. Meas. Tech., 8, 451-461, doi:10.5194/amt-8-451-2015, 2015.

Cheng, W., Ng, W. M., Huang, J., Wu, D., and Yu, J. Z.: Determination of elemental and organic carbon in $\mathrm{PM}_{2.5}$ in the Pearl River Delta Region: Inter-Instrument (Sunset vs. DRI Model 2001 Thermal/Optical Carbon Analyzer) and Inter-Protocol Comparisons (IMPROVE vs. ACE-Asia Protocol), Aerosol Sci. Tech., 46, 610-621, 2012.

Cheng, Y., He, K. B., Duan, F. K., Zheng, M., Ma, Y. L., and Tan, J. H.: Measurement of semivolatile carbonaceous aerosols and its implications: a review, Environ. Int., 35, 674681, 2009a.

Cheng, Y., He, K. B., Duan, F. K., Zheng, M., Ma, Y. L., and Tan, J. H.: Positive sampling artifact of carbonaceous aerosols and its influence on the thermal-optical split of OC/EC, Atmos. Chem. Phys., 9, 7243-7256, doi:10.5194/acp-9-7243-2009, 2009b.

Cheng, Y., He, K. B., Duan, F. K., Zheng, M., Ma, Y. L., Tan, J. H., and Du, Z. Y.: Improved measurement of carbonaceous aerosol: evaluation of the sampling artifacts and intercomparison of the thermal-optical analysis methods, Atmos. Chem. Phys., 10, 8533-8548, doi:10.5194/acp-10-8533-2010, 2010.

Cheng, Y., Duan, F. K., He, K. B., Zheng, M., Du, Z. Y., Ma, Y. L., and Tan, J. H.: Intercomparison of thermal-optical methods for the determination of organic and elemental carbon: influences of aerosol composition and implications, Environ. Sci. Technol., 45, 10117-10123, 2011.

Cheng, Y., Duan, F.-K., He, K.-B., Du, Z.-Y., Zheng, M., and Ma, Y.-L.: Sampling artifacts of organic and inorganic aerosol: implications for the speciation measurement of particulate matter, Atmos. Environ., 55, 229-233, 2012.

Cheng, Y., He, K.-B., Duan, F.-K., Du, Z.-Y., Zheng, M., and Ma, Y.-L.: Ambient organic carbon to elemental carbon ratios: influence of the thermal-optical temperature protocol and implications, Sci. Total Environ., 468, 1103-1111, 2014.

Chiappini, L., Verlhac, S., Aujay, R., Maenhaut, W., Putaud, J. P., Sciare, J., Jaffrezo, J. L., Liousse, C., Galy-Lacaux, C., Alleman, L. Y., Panteliadis, P., Leoz, E., and Favez, O.: Clues for a standardised thermal-optical protocol for the assessment of organic and elemental carbon
AMTD

8, 9649-9712, 2015

Measurement of elemental carbon

(EC) and organic carbon (OC)

A. Karanasiou et al.

\section{Title Page}

Abstract Introduction

Conclusions References

Tables Figures

14

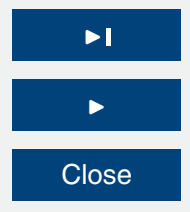

Full Screen / Esc

Printer-friendly Version

Interactive Discussion 
within ambient air particulate matter, Atmos. Meas. Tech., 7, 1649-1661, doi:10.5194/amt-71649-2014, 2014.

Chow, J. C. and Watson, J. G.: $P_{2.5}$ carbonate concentrations at regionally representative interagency monitoring of protected visual environment sites, J. Geophys. Res., 107, 8344, doi:10.1029/2001JD000574, 2002.

Chow, J. C., Watson, J. G., Pritchett, L. C., Pierson, W. R., Frazier, C. A., and Purcell, R. G.: The DRI thermal/optical reflectance carbon analysis system: description, evaluation and applications in US air quality studies, Atmos. Environ., 27, 1185-1201, 1993.

Chow, J. C., Watson, J. G., Crow, D., Lowenthal, D. H., and Merrifield, T.: Comparison of IMPROVE and NIOSH carbon measurements, Aerosol Sci. Tech., 34, 23-34, 2001.

Chow, J. C., Watson, J. G., Chen, L. W., Arnott, W. P., Moosmüller, H., and Fung, K.: Equivalence of elemental carbon thermal/optical reflectance and transmittance with different temperature protocols, Environ. Sci. Technol., 38, 4414-4422, 2004.

Chow, J. C., Watson, J. G., Louie, P. K. et al. Comparison of $\mathrm{PM}_{2.5}$ carbon measurement methods in Hong Kong, China, Environ. Pollut., 137, 334-344, 2005 a.

Chow, J. C., Watson, J. G., Chen, L.-W. A., Paredes-Miranda, G., Chang, M.-C. O., Trimble, D., Fung, K. K., Zhang, H., and Zhen Yu, J.: Refining temperature measures in thermal/optical carbon analysis, Atmos. Chem. Phys., 5, 2961-2972, doi:10.5194/acp-5-2961-2005, 2005b.

Chow, J. C., Watson, J. G., Chen, A., Chang, M. C., Robinson, N. F., Trimble, D., and Kohl, S.: The IMPROVE_A temperature protocol for thermal/optical carbon analysis: maintaining consistency with a long-term database, J. Air Waste Manage., 57, 1014-1023, 2007.

Chow, J. C., Watson, J. G., Doraiswamy, P., Chen, L.-W. A., Sodeman, D. A., Lowenthal, D. H., Park, K., Arnott, W. P., and Motallebi, N.: Aerosol light absorption, black carbon, and elemental carbon at the Fresno Supersite, California, Atmos. Res., 93, 874-887, 2009.

Chow, J. C., Watson, J. G., Chen, L.-W. A., Rice, J., and Frank, N. H.: Quantification of $\mathrm{PM}_{2.5}$ organic carbon sampling artifacts in US networks, Atmos. Chem. Phys., 10, 5223-5239, doi:10.5194/acp-10-5223-2010, 2010.

Conny, J.: The Optimization of Thermal-Optical Analysis for the Measurement of Black Carbon in Regional $\mathrm{PM}_{2.5}$ : a Chemometric Approach, US Report EPA 600/R-07/119, Environmental 30 Protection Agency, Office of Research and Development, Washington, DC, 2007.

Cuccia, E., Piazzalunga, A., Bernardoni, V., Brambilla, L., Fermo, P., Massabo, D., Molteni, U., Prati, P., Valli, G., and Vecchi, R.: Carbonate measurements in $\mathrm{PM}_{10}$ near the marble quarries of Carrara (Italy) by infrared spectroscopy (FT-IR) and source ap-
AMTD

8, 9649-9712, 2015

Measurement of elemental carbon

(EC) and organic carbon (OC)

A. Karanasiou et al.

\section{Title Page}

Abstract Introduction

Conclusions References

Tables Figures

14

4

Back

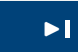

D

Close

Full Screen / Esc

Printer-friendly Version

Interactive Discussion 
portionment by positive matrix factorization (PMF), Atmos. Environ., 45, 6481-6487, doi:10.1016/j.atmosenv.2011.08.004, 2011.

Eatough, D. J., Long, R. W., Modey, W. K., and Eatough, N. L.: Semi-volatile secondary organic aerosol in urban atmospheres: meeting a measurement challenge, Atmos. Environ.,

$5 \quad 37,1277-1292,2003$.

Eatough, D., Anderson, R., Martello, D., Modey, W., and Mangelson, N.: Apportionment of ambient primary and secondary $\mathrm{PM}_{2.5}$ during a 2001 summer intensive study at the NETL Pittsburgh site using PMF2 and EPA UNMIX, Aerosol Sci. Tech., 40, 925-940, 2006.

Emblico, L., Cavalli, F., Hafkenscheid, T., and Borowiak, A.: Results of the First EC/OC Comparison Exercise For EU National Air Quality Reference Laboratories (AQUILA), JRC Technical Reports, JRC68406, EUR 25213 EN, ISBN 978-92-79-23085-1 (print), ISBN 978-9279-23086-8 (PDF), ISSN 1018-5593 (print), ISSN 1831-9424 (online), doi:10.2788/97054, Publications Office of the European Union, Luxembourg, available at: http://publications. jrc.ec.europa.eu/repository/bitstream/JRC68406/lbna25213enn.pdf (last access: September 15 2015), 2012.

EMEP: Draft Protocol For EC/OC Determination, available at: http://www.nilu.no/projects/ccc/ manual/ (last access: May 2015), 2014.

EUSAAR: Deliverable NA2/D3.1. Intercomparison of TC, OC and EC analytical method, Round Robin Test 1: May 2007, 2007.

20 EUSAAR: Deliverable NA2/D3.2. Intercomparison of TC, OC and EC analytical method, Round Robin Test 2: October 2008, 2008.

EUSAAR: Deliverable NA2/D10new. Intercomparison of TC, OC and EC analytical methods based on NIST reference material 8785, October 2009, 2009.

EUSAAR: EUSAAR-NA2 Deliverable D11new. Intercomparison of TC, OC and EC analytical methods, Round Robin Test 4: October 2010, 2010.

EUSAAR: EUSAAR-NA2 Deliverable D13new. Inter-comparison among the IMPROVE, EnVCan, and EUSAAR protocols for the analysis of particulate organic and elemental carbon deposited on filters, March 2011, 2011.

Fan, X., Brook, J. R., and Mabury, S. A.: Measurement of organic and elemental carbon associated with $\mathrm{PM}_{2.5}$ during Pacific 2001 study using an integrated organic gas and particle sampler, the Pacific 2001 Air Quality Study, Atmos. Environ., 38, 5801-5810, 2004.
AMTD

8, 9649-9712, 2015

Measurement of elemental carbon (EC) and organic carbon (OC)

A. Karanasiou et al.

\section{Title Page}

Abstract Introduction

Conclusions References

Tables Figures

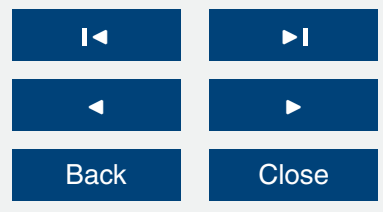

Full Screen / Esc

Printer-friendly Version

Interactive Discussion 
Flanagan, J. B., Peterson, M. R., Jayanty, R. K. M., and Rickman, E. E.: Analysis of PM ${ }_{2.5}$ Speciation Network Carbon Blank Data, Presented at the Symposium on Air Quality Measurement Methods and Technology, San Francisco, CA, 13-15 November 2002, 2002.

Fung, K. K., Chow, J. C., and Watson, J. G.: Evaluation of OC/EC speciation by thermal manganese dioxide oxidation and the IMPROVE method, J. Air Waste Manage., 52, 1333-1341, 2002.

Fuzzi, S., Andreae, M. O., Huebert, B. J., Kulmala, M., Bond, T. C., Boy, M., Doherty, S. J., Guenther, A., Kanakidou, M., Kawamura, K., Kerminen, V.-M., Lohmann, U., Russell, L. M., and Pöschl, U.: Critical assessment of the current state of scientific knowledge, terminology, and research needs concerning the role of organic aerosols in the atmosphere, climate, and global change, Atmos. Chem. Phys., 6, 2017-2038, doi:10.5194/acp-6-2017-2006, 2006.

Han, Y., Chen, A., Cao, J., Fung, K., Ho, F., Yan, B., Zhan, C., Liu, S., Wei, C., and An, Z.: Ther$\mathrm{mal} /$ optical methods for elemental carbon quantification in soils and urban dusts: equivalence of different analysis protocols, PLoS ONE, 8, e83462, doi:10.1371/journal.pone.0083462, 2013.

Hitzenberger, R., Traxler, E., and Rosati, B.: Interferences in Thermo-Optical Measurements of Elemental and Organic Carbon Caused by Other Aerosol Constituents, EAC 2011, Manchester, UK, 2011.

Huntzicker, J. J., Johnson, R. L., Shah, J. J., and Cary, R. A.: Analysis of organic and elemental carbon in ambient aerosols by a thermal-optical method, in: Particulate Carbon: Atmospheric Life Cycle, edited by: Wolff, G. T. and Klimisch, R. L., Plenum Press, New York, USA, 79-85, 1982.

Iskandar, F., Lenggoro, I., and Xia, B.: Functional nano-structured silica powders derived from colloidal suspensions by sol spraying, J. Nanopart. Res., 3, 263-270, 2001.

Jankowski, N., Schmidl, C., Marr, I. L., Bauer, H., and Puxbaum, H.: Comparison of methods for the 33 quantification of carbonate carbon in atmospheric $\mathrm{PM}_{10}$ aerosol samples, Atmos. Environ., 42, 8055-8064, 2008.

Janssen, N. A. H., Gerlofs-Nijland, M. E., Lanki, T., Salonen, R. O., Cassee, F., Hoek, G., Fischer, P., Brunekreef, B., and Krzyzanowski, M.: Health Effects of Black Carbon, The WHO European Centre for Environment and Health, Bonn, World Health Organisation Regional Office for Europe, Copenhagen, Denmark, 2012.

Jimenez, J. L., Canagaratna, M. R., Donahue, N. M., Prevot, A. S. H., Zhang, Q., Kroll, J. H., DeCarlo, P. F., Allan, J. D., Coe, H., Ng, N. L., Aiken, A. C., Docherty, K. S., Ulbrich, I. M.,

\section{AMTD}

8, 9649-9712, 2015

Measurement of elemental carbon

(EC) and organic carbon (OC)

A. Karanasiou et al.

Title Page

Abstract

Introduction

Conclusions References

Tables

Figures

14

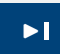

4

Back

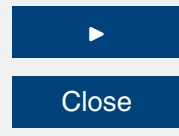

Full Screen / Esc

Printer-friendly Version

Interactive Discussion 
Grieshop, A. P., Robinson, A. L., Duplissy, J., Smith, J. D., Wilson, K. R., Lanz, V. A., Hueglin, C., Sun, Y. L., Tian, J., Laaksonen, A., Raatikainen, T., Rautiainen, J., Vaattovaara, P., Ehn, M., Kulmala, M., Tomlinson, J. M., Collins, D. R., Cubison, M. J., Dunlea, E. J., Huffman, J. a, Onasch, T. B., Alfarra, M. R., Williams, P. I., Bower, K., Kondo, Y., Schneider, J., Drewnick, F., Borrmann, S., Weimer, S., Demerjian, K., Salcedo, D., Cottrell, L., Griffin, R., Takami, A., Miyoshi, T., Hatakeyama, S., Shimono, A., Sun, J. Y., Zhang, Y. M., Dzepina, K., Kimmel, J. R., Sueper, D., Jayne, J. T., Herndon, S. C., Trimborn, A. M., Williams, L. R., Wood, E. C., Middlebrook, A. M., Kolb, C. E., Baltensperger, U., and Worsnop, D. R.: Evolution of organic aerosols in the atmosphere, Science, 326, 1525-1529, 2009.

10 John, A. C., Renker, M., and Kuhlbusch, T. A. J.: Characterization of different CNT using a thermo-optical elemental carbon/organic carbon analyzer in view of workplace aerosol measurements, European Aerosol Conference, 2-7 September 2012, Granada, Spain, 2012.

John, W. and Reischl, G. P.: A cyclone for size-selective sampling of ambient air, J. Air Pollut. 15 Control Assoc., 30, 872-876, 1980.

John, W. and Wall, S. M.: Aerosol testing techniques for size-selective samplers, J. Aerosol Sci., 14, 713-727, 1983.

Karanasiou, A., Diapouli, E., Cavalli, F., Eleftheriadis, K., Viana, M., Alastuey, A., Querol, X., and Reche, C.: On the quantification of atmospheric carbonate carbon by thermal/optical analysis 20 protocols, Atmos. Meas. Tech., 4, 2409-2419, doi:10.5194/amt-4-2409-2011, 2011.

Khan, B., Hays, M. D., Geron, C., and Jetter, J.: Differences in the OC/EC ratios that characterize ambient and source aerosols due to thermal-optical analysis, Aerosol Sci. Tech., 46, 127-137, 2012.

Kirchstetter, T. W. and Novakov, T.: Controlled generation of black carbon particles from a diffusion flame and applications in evaluating black carbon measurement methods, Atmos. Environ., 41, 1874-1888, 2007.

Kirchstetter, T. W., Corrigan, C. E., and Novakov, T.: Laboratory and field investigation of the adsorption of gaseous organic compounds onto quartz filters, Atmos. Environ., 35, 16631671, 2001.

so Klouda, G. A., Filliben, J. J., Parish, H. J., Chow, J. C., Watson, J. G., and Cary, R. A.: Reference material and 8785: air particulate matter on filter media, Aerosol Sci. Tech., 39, 173-183, 2005.

\section{AMTD}

8, 9649-9712, 2015

Measurement of elemental carbon

(EC) and organic carbon (OC)

A. Karanasiou et al.

\section{Title Page}

Abstract Introduction

Conclusions References

Tables Figures

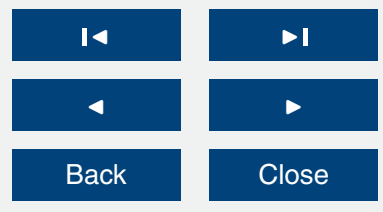

Full Screen / Esc

Printer-friendly Version

Interactive Discussion 
Kuhlbusch, T. A. J., Borowiak, A., Gelenscer, A., Genberg, J., Gladtke, D., Maenhaut, W., Pio, C., Popoviecheva, O., Putaud, J. P., Quincey, P., Sciare, J., ten Brink, H., Viana, M., and Yttri, K.-E.: Measurement of Elemental and Organic Carbon in Europe, JRC Scientific and Technical Reports, EUR 23922 EN-2009, Joint Research Center, Ispra, Italy, 2009.

5 Lee, H., Okuyama, K., and Mizohata, A.: Fabrication of reference filter for measurements of EC (elemental carbon) and OC (organic carbon) in aerosol particles, Aerosol Sci. Tech., 41, 284-294, 2007.

Lim, H. J., Turpin, B. J., Edgerton, E., Hering, S. V., Allen, G., Maring, H., and Solomon, P. A.: Semicontinuous aerosol carbon measurements: comparison of Atlanta Supersite measurements, J. Geophys. Res., 108, SOS7-1-SOS7-12, doi:10.1029/2001JD001214, 2003.

Lim, S. S., Vos, T., Flaxman, A. D., Danaei, G., Shibuya, K., Adair-Rohani, H., Amann, M., Anderson, H. R., Andrews, K. G., Aryee, M., Atkinson, C., Bacchus, L. J., Bahalim, A. N., Balakrishnan, K., Balmes, J., Barker-Collo, S., Baxter, A., Bell, M. L., Blore, J. D., Blyth, F., Bonner, C., Borges, G., Bourne, R., Boussinesq, M., Brauer, M., Brooks, P., Bruce, N. G., Brunekreef, B., Bryan-Hancock, C., Bucello, C., Buchbinder, R., Bull, F., Burnett, R. T., Byers, T. E., Calabria, B., Carapetis, J., Carnahan, E., Chafe, Z., Charlson, F., Chen, H., Chen, J. S., Cheng, A. T. A., Child, J. C., Cohen, A., Colson, K. E., Cowie, B. C., Darby, S., Darling, S., Davis, A., Degenhardt, L., Dentener, F., Des Jarlais, D. C., Devries, K., Dherani, M., Ding, E. L., Dorsey, E. R., Driscoll, T., Edmond, K., Ali, S. E., Engell, R. E., ., Falder, G., Farzadfar, F., Ferrari, A., Finucane, M. M., Flaxman, S. Fowkes, F. G. R., Freedman, G., Freeman, M. K., Gakidou, E., Ghosh, S., Giovannucci, E., Gmel, G., Graham, K., Grainger, R., Grant, B., Gunnell, D., Gutierrez, H. R., Hall, W., Hoek, H. W., Hogan, A., Hosgood, H. D., Hoy, D., Hu, H., Hubbell, B. J., Hutchings, S. J., Ibeanusi, S. E., Jacklyn, G. L., Jasrasaria, R., Jonas, J. B., Kan, H., Kanis, J. a., Kassebaum, N., Kawakami, N., Khang, Y. H., Khatibzadeh, S., Khoo, J. P., Kok, C., Laden, F., Lalloo, R., Lan, Q., Lathlean, T., Leasher, J. L., Leigh, J., Li, Y., Lin, J. K., Lipshultz, S. E., London, S., Lozano, R., Lu, Y., Mak, J., Malekzadeh, R., Mallinger, L., Marcenes, W., March, L., Marks, R., Martin, R., McGale, P., McGrath, J., Mehta, S., Mensah, G. A., Merriman, T. R., Micha, R., Michaud, C., Mishra, V., Mohd, Hanafiah, K., Mokdad, A. A., Morawska, L., Mozaffarian, D., Murphy, T., Naghavi, M., Neal, B., Nelson, P. K., Nolla, J. M., Norman, R., Olives, C., Omer, S. B., Orchard, J., Osborne, R., Ostro, B., Page, A., Pandey, K. D., Parry, C. D., Passmore, E., Patra, J., Pearce, N., Pelizzari, P. M., Petzold, M., Phillips, M. R., Pope, D., Pope, C. A., Powles, J., Rao, M., Razavi, H., Rehfuess, E. A., Rehm, J. T., Ritz, B., Rivara,
AMTD

8, 9649-9712, 2015

Measurement of elemental carbon (EC) and organic carbon (OC)

A. Karanasiou et al.

Title Page

Abstract Introduction

Conclusions References

Tables Figures

14

4

Back
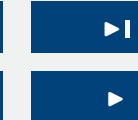

Close

Full Screen / Esc

Printer-friendly Version

Interactive Discussion 
F. P., Roberts, T., Robinson. C., Rodriguez-Portales, J. A., Romieu, I., Room, R., Rosenfeld, L. C., Roy, A., Rushton, L., Salomon, J. A., Sampson, U., Sanchez-Riera, L., Sanman, E., Sapkota, A., Seedat, S., Shi, P., Shield, K., Shivakoti, R., Singh, G. M., Sleet, D. A., Smith, E., Smith, K. R., Stapelberg, N. J., Steenland, K., Stöckl, H., Stovner, L. J., Straif, K., Straney, L., Thurston, G. D., Tran, J. H., Van Dingenen, R., van Donkelaar, A., Veerman, J. L., Vijayakumar, L., Weintraub, R., Weissman, M. M., White, R. A., Whiteford, H., Wiersma, S. T., Wilkinson, J. D., Williams, H. C., Williams, W., Wilson, N., Woolf, A. D., Yip, P., Zielinski, J. M., Lopez, A. D., Murray, C. J., Ezzati, M., AlMazroa, M. A., and Memish, Z. A.: A comparative risk assessment of burden of disease and injury attributable to 67 risk factors and risk factor clusters in 21 regions, 1990-2010: a systematic analysis for the Global Burden of Disease Study 2010, Lancet, 380, 2224-2260, 2012.

Lin, C. and Friedlander, S. K.: A note on the use of glass fiber filters in the thermal analysis of carbon containing aerosols, Atmos. Environ., 22, 605-607, 1988.

Long, R., Modey, W., Smith, P., Smith, R., Merrill, C., Pratt, J., Stubbs, A., Eatough, N. L., 15 Eatough, D. J., Malm, W. C., and Wilson, E. W.: One- and three-hour $\mathrm{PM}_{2.5}$ characterization, speciation, and source apportionment using continuous and integrated samplers, Aerosol Sci. Tech., 39, 238-248, 2005.

Mader, B. T., Flagan, R. C., and Seinfeld, J. H.: Sampling atmospheric carbonaceous aerosols using a particle trap impactor/denuder sampler, Environ. Sci. Technol., 35, 4857-4867, 2001.

Mader, B. T., Schauer, J. J., Seinfeld, J. H., Flagan, R. C., Yu, J. Z., Yang, H., Lim, H.-J., Turpin, B. J., Deminter, J. T., Heidemann, G., Bae, M. S., Quinn, P., Bates, T., Eatough, D. J., Huebert, B. J., Bertram, T., and Howell, S.: Sampling methods used for the collection of particle-phase organic and elemental carbon during ACE-Asia, Atmos. Environ., 37, 14351449, 2003.

Maenhaut, W. and Claeys, M.: EC/OC Analyses 2010-2011, Final report, Study for the Vlaamse Milieumaatschappij (VMM), afdeling Meetnetten en Onderzoek. Order number: LUC/2010/EC/OC, 25 July 2011, Flemish Environment Agency, 2011.

Maenhaut, W. and Claeys, M.: EC/OC Analyses 2011-2012, Final report, Study for the 30 Vlaamse Milieumaatschappij (VMM), afdeling Meetnetten en Onderzoek. Order number: LUC/2011/EC/OC, 15 November 2012, Flemish Environment Agency, 2012.

Maenhaut, W., Dong, S., and Chi, X.: To which extent do organic and elemental carbon data from the thermal-optical transmission technique depend upon the operational parameters

\section{AMTD}

8, 9649-9712, 2015

Measurement of elemental carbon

(EC) and organic carbon (OC)

A. Karanasiou et al.

\section{Title Page}

Abstract

Introduction

Conclusions References

Tables

Figures

14

4

Back

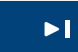

$>1$

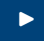

Close

Printer-friendly Version

Interactive Discussion 
used?, in: Abstract Book of the Eighth International Conference on Carbonaceous Particles in the Atmosphere, 14-16 September 2004, Vienna, Austria, 80 pp., 2004.

Maenhaut, W., Chi, X., and Wang, W.: Analysen voor EC/OC en ionen in fijn stof, 2005-2006, Eindverslag Studie in opdracht van de Vlaamse Milieumaatschappij, afdeling Meetnetten en $5 \quad$ Onderzoek Bestelnummer: LUC/2005/125, September 2006 (met correcties d.d. 2 november 2006), Flemish Environment Agency, 2006.

Maenhaut, W., Chi, X., and Dunphy, S.: Comparison of 4 temperature protocols for differentiating between $\mathrm{OC}$ and $\mathrm{EC}$ in thermal-optical transmission analysis of aerosol samples collected on quartz fibre filters, Abstract T150A0 European Aerosol Conference 2009 (EAC 2009), Karlsruhe, Germany, 6-11 September 2009, 2009.

Maenhaut, W., Claeys, M., Vercauteren, J., and Roekens, E.: Comparison of different operational parameters for thermal-optical EC/OC measurements of filter samples from Flanders, Belgium, Abstract 235 European Aerosol Conference 2012 (EAC 2012), Granada, Spain, 2-7 September 2012, 2012.

Maimone, F., Turpin, B. J., Solomon, P., Meng, Q., Robinson, A. L., Subramanian, R., and Polidori, A.: Correction methods for organic carbon artifacts when using quartz-fiber filters in large particulate matter monitoring networks: the regression method and other options, JAPCA J. Air Waste Ma., 61, 696-710, 2011.

Master, K.: Spray Drying Handbook, Longman Scientific \& Technical, Essex, UK, 1991.

20 Matsumoto, K., Uematsu, M., Hayano, T., Yoskioka, K., Tanimoto, H., and lida, T.: Simultaneous measurements of particulate elemental carbon on the ground observation network over the western North Pacific during the ACE-Asia campaign, J. Geophys. Res., 108, 8635, doi:10.1029/2002JD002744, 2003.

McDow, S. R. and Huntzicker, J. J.: Vapor adsorption artifact in the sampling of organic aerosol: face velocity effects, Atmos. Environ., 24, 2563-2571, 1990.

Mikuska, P., Vecera, Z., Bartosíková A, and Maenhaut, W.: Annular diffusion denuder for simultaneous removal of gaseous organic compounds and air oxidants during sampling of carbonaceous aerosols, Anal. Chim. Acta, 714, 68-75, 2012.

Miyazaki, Y., Kondo, Y., Han, S., Koike, M., Kodama, D., Komazaki, Y., Tanimoto, H., and Mat30 sueda, $\mathrm{H}$.: Chemical characteristics of water-soluble organic carbon in the Asian Outflow, J. Geophys. Res., 112, D22S30, doi:10.1029/2007JD009116, 2007.

\section{AMTD}

8, 9649-9712, 2015

Measurement of elemental carbon

(EC) and organic carbon (OC)

A. Karanasiou et al.

\section{Title Page}

Abstract Introduction

Conclusions References

Tables Figures

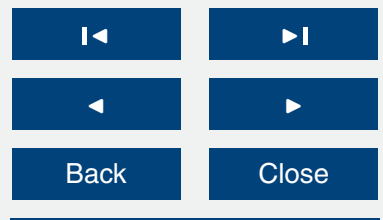

Full Screen / Esc

Printer-friendly Version

Interactive Discussion 
Mkoma, S. L., Wang, W., Maenhaut, W., and Tungaraza, C. T.: Seasonal variation of atmospheric composition of water-soluble inorganic species at rural background site in Tanzania, East Africa, Ethiopian Journal of Environmental Studies and Management, 3, 27-38, 2010.

Modey, W., Eatough, D., Anderson, R., Martello, D., Takahama, S., and Lucas, L.: Ambient fine 5 particulate concentrations and chemical composition at two sampling sites in metropolitan Pittsburgh: a 2001 intensive summer study, Atmos. Environ., 38, 3165-3178, 2004.

NIOSH: Elemental Carbon (Diesel Particulate): Method 5040, in: NIOSH Manual of Analytical Methods, 4th edn. (1st Supplement), edited by: Eller, P. M. and Cassinelli, M. E., National Institute for Occupational Safety and Health, DHHS (NIOSH), Cincinnati, OH, USA, Publication No. 96-135, 1996.

Novakov, T. and Corrigan, C. E.: Thermal characterization of biomass smoke particles, Microchim. Acta, 119, 157-166, 1995.

Olson, D. A. and Norris, G. A.: Sampling artifacts in measurement of elemental and organic carbon: low-volume sampling in indoor and outdoor environments, Atmos. Environ., 39, 543715 5445, 2005.

Panteliadis, P., Hafkenscheid, T., and Maenhaut, W.: ECOC Comparison Exercise With Identical Thermal Protocols After Temperature Offsets Correction, GGD Amsterdam, GGD/LO 131153, 63 pp., 2013.

Panteliadis, P., Hafkenscheid, T., Cary, B., Diapouli, E., Fischer, A., Favez, O., Quincey, P., Viana, M., Hitzenberger, R., Vecchi, R., Saraga, D., Sciare, J., Jaffrezo, J. L., John, A., Schwarz, J., Giannoni, M., Novak, J., Karanasiou, A., Fermo, P., and Maenhaut, W.: ECOC comparison exercise with identical thermal protocols after temperature offset correction - instrument diagnostics by in-depth evaluation of operational parameters, Atmos. Meas. Tech., 8, 779-792, doi:10.5194/amt-8-779-2015, 2015.

Pavlovic, J., Kinsey, J. S., and Hays, M. D.: The influence of temperature calibration on the OCEC results from a dual-optics thermal carbon analyzer, Atmos. Meas. Tech., 7, 2829-2838, doi:10.5194/amt-7-2829-2014, 2014.

Perrone, M. R., Piazzalunga, A., Prato, M., and Carofalo, I.: Composition of fine and coarse particles in a coastal site of the central Mediterranean: carbonaceous species contributions, 30 Atmos. Environ., 45, 7470-7477, 2011.

Peterson, M. R. and Richards, M.H: Thermal-optical-transmittance analysis for organic, elemental, carbonate, total carbon, and $\mathrm{OCX} 2$ in $\mathrm{PM}_{2.5}$ by the EPA/NIOSH method, presentation at the Symposium on Air Quality Measurement Methods and Technology in San Francisco,

\section{AMTD}

8, 9649-9712, 2015

Measurement of elemental carbon

(EC) and organic carbon (OC)

A. Karanasiou et al.

\section{Title Page}

Abstract

Introduction

Conclusions References

Tables

Figures

14

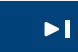

4

Back

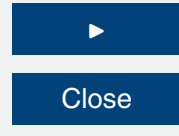

Full Screen / Esc

Printer-friendly Version

Interactive Discussion 
CA, 13-15 November 2002, J. Air Waste Manage. Assoc., Pittsburgh, PA, USA, Session 5, Paper \#83, 2002.

Petzold, A., Ogren, J. A., Fiebig, M., Laj, P., Li, S.-M., Baltensperger, U., Holzer-Popp, T., Kinne, S., Pappalardo, G., Sugimoto, N., Wehrli, C., Wiedensohler, A., and Zhang, X.-Y.: 5 Recommendations for reporting "black carbon" measurements, Atmos. Chem. Phys., 13, 8365-8379, doi:10.5194/acp-13-8365-2013, 2013.

Phuah, C. H., Peterson, M. R., Richards, M. H., Turner, J. H., and Dillner, A. M.: A temperature calibration procedure for the sunset laboratory carbon aerosol analysis lab instrument, Aerosol Sci. Tech., 43, 1013-1021, doi:10.1080/02786820903124698, 2009.

10 Piazzalunga, A., Belis, C., Bernardoni, V., Cazzuli, O., Fermo, P., Valli, G., and Vecchi, R.: Estimates of wood burning contribution to PM by the macro-tracer method using tailored emission factors, Atmos. Environ., 45, 6642-6649, 2011.

Popovicheva, O., Baumgardner, D., Subramanian, R., Kok, G., Cary, R., Vlasenko, E., Khokhlova, T., Shonija, N., and Kireeva, E.: Tailored graphitized soot as reference material for EC/OC measurement validation, Atmos. Meas. Tech., 4, 923-932, doi:10.5194/amt-4923-2011, 2011.

Putaud, J. P. and Cavalli, F.: Development and Validation of Standardized Protocols For Sampling OC and Analysing OC + EC For the EMEP Network, EME, available at: http: //www.nilu.no/projects/ccc/reports.html (last access: April 2015), 2006.

Putaud, J. P., Raes, F., Van Dingenen, R., Brueggemann, E., Facchini, M. C., Decesari, S., Fuzzi, S., Gehrig, R., Hüglin, C., Laj, P., Lorbeer, G., Maenhaut, W., Mihalopoulos, N., Müller, K., Querol, X., Rodriguez, S., Schneider, J., Spindler, G., Brink, H. ten, Tørseth, K., and Wiedensohler, A.: European aerosol phenomenology - 2: Chemical characteristics of particulate matter at kerbside, urban, rural and background sites in Europe, Atmos. Environ., 38, 2579-2595, 2004.

Putaud, J. P., Van Dingenen, R., Alastuey, A., Bauer, H., Birmili, W., Cyrys, J., Flentje, H., Fuzzi, S., Gehrig, R., Hansson, H., Harrison, R., Herrmann, H., Hitzenberger, R., Huglin, C., Jones, A., Kasper-Giebl, A., Kiss, G., Kousa, A., Kuhlbusch, T., Loschau, G., Maenhaut, W., Molnar, A., Moreno, T., Pekkanen, J., Perrino, C., Pitz, M., Puxbaum, H., Querol, X., Rodriguez, S., Salma, I., Schwarz, J., Smolik, J., Schneider, J., Spindler, G., ten Brink, H., Tursic, J., Viana, M., Wiedensohler, A., and Raes, F.: A European aerosol phenomenology - 3: Physical and chemical characteristics of particulate matter from 60 rural, urban, and kerbside sites across Europe, Atmos. Environ., 44, 1308-1320, 2010.

\section{AMTD}

8, 9649-9712, 2015

Measurement of elemental carbon (EC) and organic carbon (OC)

A. Karanasiou et al.

\section{Title Page}

Abstract Introduction

Conclusions References

Tables Figures

14

4

Back
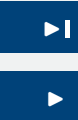

Close

Full Screen / Esc

Printer-friendly Version

Interactive Discussion 
Puxbaum, H.: Thermo-Gasanalysator zur Charakterisierung von Kohlenstoff- und Schwefelverbindungen in luftgetragenen Stäuben, Fresen. Z. Anal. Chem., 299, 33-41, 1979.

Querol, X., Alastuey, A., Ruiz, C. R., Artiñano, B., Hansson, H. C., Harrison, R. M., Buringh, E., ten Brink, H. M., Lutz, M., Bruckmann, P., Straehl, P., and Schneider, J.: Speciation and origin of $\mathrm{PM}_{10}$ and $\mathrm{PM}_{2.5}$ in selected European cities, Atmos. Environ., 38, 6547-6555, 2004.

Querol, X., Moreno, T., Karanasiou, A., Reche, C., Alastuey, A., Viana, M., Font, O., Gil, J., de Miguel, E., and Capdevila, M.: Variability of levels and composition of $\mathrm{PM}_{10}$ and $\mathrm{PM}_{2.5}$ in the Barcelona metro system, Atmos. Chem. Phys., 12, 5055-5076, doi:10.5194/acp-125055-2012, 2012.

Querol, X., Alastuey, A., Viana, M., Moreno, T., Reche, C., Minguillón, M. C., Ripoll, A., Pandolfi, M., Amato, F., Karanasiou, A., Pérez, N., Pey, J., Cusack, M., Vázquez, R., Plana, F., Dall'Osto, M., de la Rosa, J., Sánchez de la Campa, A., Fernández-Camacho, R., Rodríguez, S., Pio, C., Alados-Arboledas, L., Titos, G., Artíñano, B., Salvador, P., García Dos Santos, S., and Fernández Patier, R.: Variability of carbonaceous aerosols in remote, rural, urban and industrial environments in Spain: implications for air quality policy, Atmos. Chem. Phys., 13, 6185-6206, doi:10.5194/acp-13-6185-2013, 2013.

Quincey, P., Butterfield, D., Green, D., Coyle, M., and Cape, J. N.: An evaluation of measurement methods for organic, elemental and black carbon in ambient air monitoring sites, Atmos. Environ., 43, 5085-5091, 2009.

20 Reisinger, P., Wonaschütz, A., Hitzenberger, R., Petzold, A., Bauer, H., Jankowski, N., Puxbaum, H., Chi, X., and Maenhaut, W.: Intercomparison of measurement techniques for black or elemental carbon under urban background conditions in wintertime: influence of biomass combustion, Environ. Sci. Technol., 42, 884-889, 2008.

Robles, J.A, Chow, J. C., and Watson, J. G.: Carbonate and Mineral Interference during Thermal Optical Analysis, Proceedings 10th International Conference on Carbonaceous Particles in the Atmosphere 26th to 29th June, Vienna, Austria, p. 18, 2011.

Roth, C., Ferron, G. A., Karg, E., Lentner, B., Schumann, G., Takenaka, S., and Heyder, J.: Generation of ultrafine particles by spark discharging, Aerosol Sci. Tech., 38, 228-235, 2004.

Saleh, R., Hennigan, C. J., McMeeking, G. R., Chuang, W. K., Robinson, E. S., Coe, H., Donahue, N. M., and Robinson, A. L.: Absorptivity of brown carbon in fresh and photo-chemically aged biomass-burning emissions, Atmos. Chem. Phys., 13, 7683-7693, doi:10.5194/acp-137683-2013, 2013.
AMTD

8, 9649-9712, 2015

Measurement of elemental carbon (EC) and organic carbon (OC)

A. Karanasiou et al.

\section{Title Page}

Abstract Introduction

Conclusions References

Tables Figures

14

4

Back

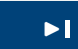

$>$

Close

Printer-friendly Version

Interactive Discussion 
Salma, I., Chi, X., and Maenhaut, W.: Elemental and organic carbon in urban canyon and background environments in Budapest, Hungary, Atmos. Environ., 38, 27-36, 2004.

Salma, I. Ocskay, R., Chi, X., and Maenhaut, W.: Sampling artefacts, concentrations and chemical composition of fine watersoluble organic carbon and humic-like substances in a continental urban atmospheric environment, Atmos. Environ., 41, 4106-4118, 2007.

Schauer, J. J., Mader, B. T., Deminter, J. T., Heidemann, G., Bae, M. S., Seinfeld, J. H., Flagan, R. C., Cary, R. A., Smith, D., Huebert, B. J., Bertram, T., Howell, S., Kline, J. T., Quinn, P., Bates, T., Turpin, B., Lim, H. J., Yu, J. Z., Yang, H., and Keywood, M. D.: ACE-Asia intercomparison of a thermal-optical method for the determination of particle-phase organic and elemental carbon, Environ. Sci. Technol., 37, 993-1001, 2003.

Schmid, H., Laskus, L., Jürgen Abraham, H., Baltensperger, U., Lavanchy, V., Bizjak, M., Burba, P., Cachier, H., Crow, D., Chow, J., Gnauk, T., Even, A., ten Brink, H. M., Giesen, K. P., Hitzenberger, R., Hueglin, C., Maenhaut, W., Pio, C., Carvalho, A., Putaud, J. P., ToomSauntry, D., and Puxbaum, H.: Results of the "carbon conference" international aerosol carbon round robin test stage I, Atmos. Environ., 35, 2111-2121, 2001.

Schmid, J., Grob, B., Niessner, R., and Ivleva, N.: Multi-wavelength raman microspectroscopy for rapid prediction of soot oxidation reactivity, Anal. Chem., 83, 1173-1179, 2011.

Sciare, J., Oikonomou, K., Favez, O., Liakakou, E., Markaki, Z., Cachier, H., and Mihalopoulos, N.: Long-term measurements of carbonaceous aerosols in the Eastern Mediterranean: evidence of long-range transport of biomass burning, Atmos. Chem. Phys., 8, 5551-5563, doi:10.5194/acp-8-5551-2008, 2008.

Sharma, S., Brook, J. R., Cachier, H., Chow, J. C., Gaudenzi, A., and Lu, G.: Light absorption and thermal measurements of black carbon in different regions of Canada, J. Geophys. Res., 107, 4771, doi:10.1029/2002JD002496, 2002.

Shindell, D., Kuylenstierna, J. C. I., Vignati, E., van Dingenen, R., Amann, M., Klimont, Z., Anenberg, S. C., Muller, N., Janssens-Maenhout, G., Raes, F., Schwartz, J., Faluvegi, G., Pozzoli, L., Kupiainen, K., Höglund-Isaksson, L., Emberson, L., Streets, D., Ramanathan, V., Hicks, K., Oanh, N. T. K., Milly, G., Williams, M., Demkine, V., and Fowler, D.: Simultaneously mitigating near-term climate change and improving human health and food security, Science, 30 335, 183-189, 2012.

Sin, D. W. M., Fung, W. H., and Lam, C. H.: Measurement of carbonaceous aerosols: validation and comparison of a solvent extraction - gas chromatographic method and a thermal optical transmittance method, Analyst, 127, 614-622, 2002.

\section{AMTD}

8, 9649-9712, 2015

Measurement of elemental carbon

(EC) and organic carbon (OC)

A. Karanasiou et al.

\section{Title Page}

Abstract Introduction

Conclusions References

Tables Figures

14

4

Back

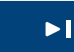

$>$

Close

Printer-friendly Version

Interactive Discussion 
Solomon, P. A., Mitchell, W., Gemmill, D., Tolocka, M., Norris, G., Wiener, R., Eberly, J., Rice, J., Homolya, J., Scheffe, R., Vanderpool, R., Murdoch, R., Natarajan, S., and Hardison, E.: Evaluation of $\mathrm{PM}_{2.5}$ Chemical Speciation Samplers for Use in the US EPA National $\mathrm{PM}_{2.5}$ Chemical Speciation Network, US EPA, 2000.

5 Soto-García, L. L., Andreae, M. O., Andreae, T. W., Artaxo, P., Maenhaut, W., Kirchstetter, T., Novakov, T., Chow, J. C., and Mayol-Bracero, O. L.: Evaluation of the carbon content of aerosols from the burning of biomass in the Brazilian Amazon using thermal, optical and thermal-optical analysis methods, Atmos. Chem. Phys., 11, 4425-4444, doi:10.5194/acp11-4425-2011, 2011.

10 Stipte, C. B., Higgins, B. S., Lucas, D., Koshland, C. P., and Sawyer, R. F.: Inverted co-flow diffusion flame for producing soot, Rev. Sci. Instrum., 76, 023908, doi:10.1063/1.1851492, 2005.

Subramanian, R., Khlystov, A. Y., Cabada, J. C., and Robinson, A. L.: Positive and negative artifacts in particulate organic carbon measurement with denuded and undenuded sampler configurations, Aerosol Sci. Tech., 38, 27-48, 2004.

Subramanian, R., Khlystov, A. Y., and Robinson, A. L.: Effect of peak inert-mode temperature on elemental carbon measured using thermal-optical analysis, Aerosol Sci. Tech., 40, 763780, 2006.

ten Brink, $\mathrm{H} .:$ Artefacts in measuring (the composition of) particulate matter in Europe: introducing INTERCOMP2000, Atmos. Environ., 38, 6457, doi:10.1016/j.atmosenv.2004.08.028, 2004.

ten Brink, H. M., Weijers, E. P., Van Arkel, F. Th., and De Jonge, D.: Carbon (EC/OC) Concentrations as Derived From Routine PM Measurements in the Netherlands, Netherlands Research Program on Particulate Matter (BOP), Report 500099005, Netherlands Environmental Assessment Agency, Bilthoven, the Netherlands, 2009.

Turpin, B. J. and Huntzicker, J. J.: Investigation of organic aerosol sampling artifacts in the Los Angeles basin, Atmos. Environ., 28, 3061-3071, 1994.

Turpin, B. J., Saxena, P., and Andrews, E.: Measuring and simulating particulate organics in the atmosphere: problems and prospects, Atmos. Environ., 34, 2983-3013, 2000.

30 Vecchi, R., Valli, G., Fermo, P., D’Alessandro, A., Piazzalunga, A., and Bernardoni, V.: Organic and inorganic sampling artefacts assessment, Atmos. Environ., 43, 1713-1720, 2009.
AMTD

8, 9649-9712, 2015

Measurement of elemental carbon (EC) and organic carbon (OC)

A. Karanasiou et al.

Title Page

Abstract Introduction

Conclusions References

Tables Figures

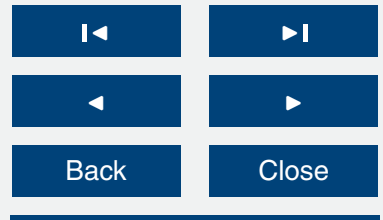

Full Screen / Esc

Printer-friendly Version

Interactive Discussion 
Viana, M., Chi, X., Maenhaut, W., Querol, X., Alastuey, A., Mikuška, P., and Večeřa, Z.: Organic and elemental carbon concentrations during summer and winter sampling campaigns in Barcelona, Spain, Atmos. Environ., 40, 2180-2193, 2006a.

Viana, M., Chi, X., Maenhaut, W., Cafmeyer, J., Querol, X., Alastuey, A., Mikuška, P., and 5 Večeřa, Z.: Influence of sampling artefacts on measured PM, OC and EC levels in carbonaceous aerosols in an urban area, Aerosol Sci. Tech., 40, 107-117, 2006b.

Viana, M., Maenhaut, W., ten Brink, H. M., Chi, X., Weijers, E., Querol, X., Alastuey, A., Mikuška, P., and Večeřa, Z.: Comparative analysis of organic and elemental carbon concentrations in carbonaceous aerosols in three European cities, Atmos. Environ., 41, 5972-5983, 2007.

Wang, Y., Chung, A., and Paulson, S. E.: The effect of metal salts on quantification of elemental and organic carbon in diesel exhaust particles using thermal-optical evolved gas analysis, Atmos. Chem. Phys., 10, 11447-11457, doi:10.5194/acp-10-11447-2010, 2010.

Watson, J. G., Chow, J. C., and Wa, L.: Summary of organic and elemental carbon/black carbon 15 analysis methods and intercomparisons, Aerosol Air Qual. Res., 5, 65-102, 2005.

Watson, J. G., Chow, J. C., and Chen, L. W. A.: Assessment of carbon sampling artefacts in the IMPROVE, STN/CSN, and SEARCH networks U. S. Environmental Protection Agency (MD-14) Research Triangle Park, North Carolina, USA, 122, 2007.

Webb, T. L. and Kruger, J. E.: Carbonates, in: Differential Thermal Analysis, edited by: MacKenzie, R. C., Academic Press, New York, USA, 303-341, 1970.

Wu, C., Man Ng, W., Huang, J., Wu, D., and Yu, J. Z.: Determination of elemental and organic carbon in $\mathrm{PM}_{2.5}$ in the Pearl River Delta region: Inter-Instrument (Sunset vs. DRI Model 2001 Thermal/Optical Carbon Analyzer) and Inter-Protocol Comparisons (IMPROVE vs. ACE-Asia Protocol), Aerosol Sci. Tech., 46, 610-621, 2012.

Xu, J., Bergin, M. H., Greenwald, R., Schauer, J. J., Shafer, M. M., Jaffrezo, J. L., and Aymoz, G.: Aerosol chemical, physical, and radiative characteristics near a desert source region of northwest China during ACE-Asia, J. Geophys. Res., 109, D19S03, doi:10.1029/2003JD004239, 2004.

Yang, H. S. and Yu, J. Z.: Uncertainties in charring correction in the analysis of elemental and 30 organic carbon in atmospheric particles by thermal/optical methods, Environ. Sci. Technol., 36, 5199-5124, 2002.

Yttri, K. E., Aas, W., Bjerke, A., Cape, J. N., Cavalli, F., Ceburnis, D., Dye, C., Emblico, L., Facchini, M. C., Forster, C., Hanssen, J. E., Hansson, H. C., Jennings, S. G., Maenhaut, W.,

\section{AMTD}

8, 9649-9712, 2015

Measurement of elemental carbon

(EC) and organic carbon (OC)

A. Karanasiou et al.

\section{Title Page}

Abstract Introduction

Conclusions References

Tables Figures

14

4

Back

Full Screen / Esc

Printer-friendly Version

Interactive Discussion 
Putaud, J. P., and Tørseth, K.: Elemental and organic carbon in $\mathrm{PM}_{10}$ : a one year measurement campaign within the European Monitoring and Evaluation Programme EMEP, Atmos. Chem. Phys., 7, 5711-5725, doi:10.5194/acp-7-5711-2007, 2007.

Yttri, K. E., Dye, C., Braathen, O.-A., Simpson, D., and Steinnes, E.: Carbonaceous aerosols in $5 \quad$ Norwegian urban areas, Atmos. Chem. Phys., 9, 2007-2020, doi:10.5194/acp-9-2007-2009, 2009.

Yu, Z. J., Xu, J. H., and Yang, H.: Charring characteristics of atmospheric organic particulate matter in thermal analysis, Environ. Sci. Technol., 36, 754-761, 2002.

Zhang, Y. L., Perron, N., Ciobanu, V. G., Zotter, P., Minguillón, M. C., Wacker, L., Prévôt, A. S. H., Baltensperger, U., and Szidat, S.: On the isolation of OC and EC and the optimal strategy of radiocarbon-based source apportionment of carbonaceous aerosols, Atmos. Chem. Phys., 12, 10841-10856, doi:10.5194/acp-12-10841-2012, 2012.

Zhi, G., Chen, Y., Sheng, G., and Fu, J.: Effects of temperature parameters on thermal-optical analysis of organic and elemental carbon in aerosol, Environ. Monit. Assess., 154, 253-261, 152009.

Zhi, G. R., Chen, Y. J., Sun, J. Y., Chen, L. G., Tian, W. J., Duan, J. C., Zhang, G., Chai, F. H., Sheng, G. Y., and Fu, J. M.: Harmonizing aerosol carbon measurements between two conventional thermal/optical analysis methods, Environ. Sci. Technol., 45, 2902-2908, 2011.

20 Zhu, C. S., Tsai, C. J., Chen, S. C., Cao, J. J., and Roam, G. D.: Positive sampling artifacts of organic carbon fractions for fine particles and nanoparticles in a tunnel environment, Atmos. Environ., 54, 225-230, 2012.

\section{AMTD}

8, 9649-9712, 2015

Measurement of elemental carbon

(EC) and organic carbon (OC)

A. Karanasiou et al.

Title Page

Abstract Introduction

Conclusions References

Tables

Figures

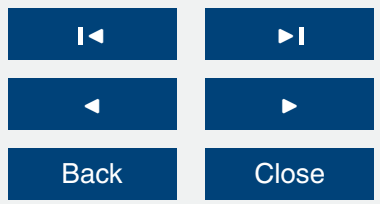

Full Screen / Esc

Printer-friendly Version

Interactive Discussion 
Table 1. Summary of thermal-optical protocols (updated from Watson et al., 2005).

\begin{tabular}{|c|c|c|c|c|c|c|c|c|c|}
\hline Protocol & $\begin{array}{l}\text { Carrier gas } \\
\text { OC }\end{array}$ & $\begin{array}{l}\text { Temperature steps } \\
\text { OC, }{ }^{\circ} \mathrm{C}\end{array}$ & Time, s for OC & Carrier gas EC & $\begin{array}{l}\text { Temperature steps } \\
\mathrm{EC},{ }^{\circ} \mathrm{C}\end{array}$ & Time, s for EC & Correction & Detector & Reference \\
\hline OGI & $\mathrm{He}$ & 600 & Varies & $98 \% \mathrm{He} 2 \% \mathrm{O}_{2}$ & $400,450,600$ & $\begin{array}{ll}100, & 120, \quad> \\
200 & \end{array}$ & Reflectance & $\mathrm{FID} / \mathrm{CH}_{4}$ & $\begin{array}{l}\text { Huntzicker } \\
\text { et al. (1982) }\end{array}$ \\
\hline IMPROVE & $\mathrm{He}$ & $120,250,450,550$ & $150-580^{a}$ & $98 \% \mathrm{He} 2 \% \mathrm{O}_{2}$ & $550,700,800$ & $150-580^{a}$ & Reflectance & $\mathrm{FID} / \mathrm{CH}_{4}$ & $\begin{array}{l}\text { Chow et al. (1993, } \\
\text { 2001, 2004) }\end{array}$ \\
\hline $\mathrm{NIOSH} 5040$ & $\mathrm{He}$ & $250,500,650,850$ & $60,60,60,90$ & $98 \% \mathrm{He} 2 \% \mathrm{O}_{2}$ & $650,750,860,940$ & $\begin{array}{l}30,30,30,> \\
120\end{array}$ & Transmittance & $\mathrm{FID} / \mathrm{CH}_{4}$ & $\begin{array}{l}\text { NIOSH, (1996); } \\
\text { Birch (1998) }\end{array}$ \\
\hline CalTech & $\mathrm{He}$ & $310,450,575,870$ & $60,60,60,90$ & $90 \% \mathrm{He} 2 \% \mathrm{O}_{2}$ & $\begin{array}{l}550, \quad 625, \quad 700, \\
775, \\
850,900\end{array}$ & $\begin{array}{l}45,45,45,45 \\
45,120\end{array}$ & Transmittance & $\mathrm{FID} / \mathrm{CH}_{4}$ & Mader et al. (2001) \\
\hline MSC1 & $\mathrm{He}$ & $250,450,550,900$ & $150,150,180,90$ & $\begin{array}{l}90 \% \mathrm{He} \\
10 \% \mathrm{O}_{2}\end{array}$ & $550,700,800$ & $240,210,150$ & Transmittance & $\mathrm{FID} / \mathrm{CH}_{4}$ & Sharma et al. (2002) \\
\hline $\begin{array}{l}\text { STN or } \\
\text { EPA/NIOSH }\end{array}$ & $\mathrm{He}$ & $310,475,615,900$ & $60,60,60,90$ & $98 \% \mathrm{He} 2 \% \mathrm{O}_{2}$ & $\begin{array}{lll}600, & 675, & 750, \\
825, & & \\
920 & & \end{array}$ & $\begin{array}{l}45,45,45,45 \\
120\end{array}$ & Transmittance & $\mathrm{FID} / \mathrm{CH}_{4}$ & $\begin{array}{l}\text { Peterson and } \\
\text { Richards (2002) }\end{array}$ \\
\hline HKGL & $\mathrm{He}$ & $350,550,850$ & $70,70,110$ & $95 \% \mathrm{He} 5 \% \mathrm{O}_{2}$ & $\begin{array}{l}550,600, \quad 700, \\
750, \\
800,850\end{array}$ & $\begin{array}{l}10,50,40,30 \\
30,70\end{array}$ & Transmittance & $\mathrm{FID} / \mathrm{CH}_{4}$ & $\begin{array}{l}\text { Sin et al. (2002); } \\
\text { Chow et al. (2005a) }\end{array}$ \\
\hline HKUST-3 & $\mathrm{He}$ & $250,500,650,850$ & $\begin{array}{l}150,150,150, \\
150\end{array}$ & $99 \% \mathrm{He} 1 \% \mathrm{O}_{2}$ & $650,750,850,890$ & $\begin{array}{l}150,150,150, \\
150\end{array}$ & Transmittance & $\mathrm{FID} / \mathrm{CH}_{4}$ & $\begin{array}{l}\text { Yang and Yu (2002); } \\
\text { Yu et al. (2002) }\end{array}$ \\
\hline $\mathrm{RU} / \mathrm{OGI}$ & $\mathrm{He}$ & stepwise to 700 & NA & $90 \% \mathrm{He} 2 \% \mathrm{O}_{2}$ & stepwise to 700 & NA & Transmittance & $\mathrm{FID} / \mathrm{CH}_{4}$ & Lim et al. (2003) \\
\hline ACE-Asia ${ }^{b}$ & $\mathrm{He}$ & $\begin{array}{l}340,500,615,870 \\
\text { oven off }\end{array}$ & $60,60,60,90,45$ & $98 \% \mathrm{He} 2 \% \mathrm{O}_{2}$ & $\begin{array}{l}550,625,700,775, \\
850,900\end{array}$ & $\begin{array}{l}45,45,45,45, \\
45,120\end{array}$ & Transmittance & $\mathrm{FID} / \mathrm{CH}_{4}$ & Schauer et al. (2003) \\
\hline $\begin{array}{l}\text { IMPROVE- } \\
\text { like }\end{array}$ & $\mathrm{He}$ & $\begin{array}{l}120,250,450,550, \\
\text { oven off }\end{array}$ & $60,60,60,90,45$ & $98 \% \mathrm{He} 2 \% \mathrm{O}_{2}$ & $\begin{array}{l}550,625,700,775, \\
850, \\
900\end{array}$ & $\begin{array}{l}45,45,45,45 \\
45,120\end{array}$ & Transmittance & $\mathrm{FID} / \mathrm{CH}_{4}$ & Schauer et al. (2003) \\
\hline IMPROVE_A & $\mathrm{He}$ & $140,280,480,580$ & $150-580^{a}$ & $98 \% \mathrm{He} 2 \% \mathrm{O}_{2}$ & $580,740,840$ & $150-580^{a}$ & Reflectance & $\mathrm{FID} / \mathrm{CH}_{4}$ & Chow et al. (2007) \\
\hline NIST-EPA & $\mathrm{He}$ & $\begin{array}{lll}200, & 400, & 600, \\
785, & & \\
550 & & \end{array}$ & $\begin{array}{l}60,60,60,150, \\
60\end{array}$ & $98 \% \mathrm{He} 2 \% \mathrm{O}_{2}$ & $\begin{array}{l}620,690,760,830, \\
900\end{array}$ & $\begin{array}{l}60,60,60, \\
45,90\end{array}$ & Transmittance & $\mathrm{FID} / \mathrm{CH}_{4}$ & Conny (2007) \\
\hline Quartz.par & $\mathrm{He}$ & $220,360,525,850$ & $60,60,60,90$ & $98 \% \mathrm{He} 2 \% \mathrm{O}_{2}$ & $\begin{array}{l}550,650,720,790, \\
820, \\
860,890\end{array}$ & $\begin{array}{l}30,30,30 \\
40,30,20,40\end{array}$ & Transmittance & $\mathrm{FID} / \mathrm{CH}_{4}$ & Yttri et al. (2009) \\
\hline Quartz & $\mathrm{He}$ & $\begin{array}{l}310,475,615,870, \\
\text { oven off }\end{array}$ & $\begin{array}{l}70-80, \quad 60,60, \\
90-105,45\end{array}$ & $98 \% \mathrm{He} 2 \% \mathrm{O}_{2}$ & $\begin{array}{l}525-550,625,700 \\
775-850,870-890\end{array}$ & $\begin{array}{l}45-60, \\
45-60, \\
45-60,60,90\end{array}$ & Transmittance & $\mathrm{FID} / \mathrm{CH}_{4}$ & $\begin{array}{l}\text { Quincey et al. (2009); } \\
\text { Querol et al. (2013) }\end{array}$ \\
\hline EUSAAR_1 & $\mathrm{He}$ & $200,300,450,650$ & $\begin{array}{l}120,150, \quad 180 \\
180\end{array}$ & $98 \% \mathrm{He} 2 \% \mathrm{O}_{2}$ & 550,850 & 240,150 & Transmittance & $\mathrm{FID} / \mathrm{CH}_{4}$ & EUSAAR (2007) \\
\hline EUSAAR_2 & $\mathrm{He}$ & $200,300,450,650$ & $\begin{array}{lll}120, & 150, & 180 \\
180 & \end{array}$ & $98 \% \mathrm{He} 2 \% \mathrm{O}_{2}$ & $500,550,700,850$ & $\begin{array}{l}120,120,70, \\
80\end{array}$ & Transmittance & $\mathrm{FID} / \mathrm{CH}_{4}$ & Cavalli et al. (2010) \\
\hline
\end{tabular}

${ }^{\text {a }}$ Advance from one temperature to the next one when a well-defined carbon peak has evolved.

${ }^{\mathrm{b}} \mathrm{NIOSH}$-like protocol used for the laboratory intercomparison in the ACE-Asia project.

\section{AMTD}

8, 9649-9712, 2015

\section{Measurement of elemental carbon (EC) and organic carbon (OC)}

A. Karanasiou et al.

\section{Title Page}

Abstract

Introduction

Conclusions

References

Tables

Figures

14

4

Back

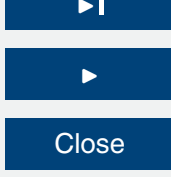

Full Screen / Esc

Printer-friendly Version

Interactive Discussion 
Table 2. Analytical characteristics of the most commonly used thermal-optical protocols.

\begin{tabular}{|c|c|c|c|c|c|}
\hline Protocol & Aerosol type & $\begin{array}{l}\text { Operational } \\
\text { range, } \\
\mu \mathrm{gC} \mathrm{cm}\end{array}$ & $\begin{array}{l}\text { Limit of } \\
\text { detection, } \\
\mu \mathrm{gC} \mathrm{cm}\end{array}$ & $\begin{array}{l}\text { Accuracy, } \\
\%\end{array}$ & $\begin{array}{l}\text { Precision, } \\
\mu \mathrm{gCcm}^{-2}\end{array}$ \\
\hline NIOSH5040 & Diesel exhaust & $0.7-70$ & 0.15 & $\begin{array}{l} \pm 16.7 \\
\left(\text { at } 23 \mu \mathrm{g} \mathrm{Ccm}^{-3} \text { ) }\right.\end{array}$ & $\begin{array}{l} \pm 0.13 \text { for loadings } \\
\text { of } 0.67 \mu \mathrm{g} \mathrm{cm}^{-2} \\
\pm 0.007 \text { for loadings } \\
6.67-48 \mu \mathrm{g} \mathrm{cm}^{-2}\end{array}$ \\
\hline IMPROVE_A & $\begin{array}{l}\text { IMPROVE } \\
\text { network }\end{array}$ & $0.2-750$ & 0.2 & $\begin{array}{l}<10 \\
\text { (TC accuracy) }\end{array}$ & 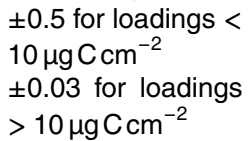 \\
\hline EUSAAR_2 & EMEP network & $5-62$ & - & $\begin{array}{l}2-7 \text { uncertainty } \\
\text { for EC }\end{array}$ & - \\
\hline
\end{tabular}

AMTD

8, 9649-9712, 2015

\section{Measurement of elemental carbon (EC) and organic carbon (OC)}

A. Karanasiou et al.

Title Page

Abstract

Introduction

Conclusions

References

Tables

Figures

14

4

Back

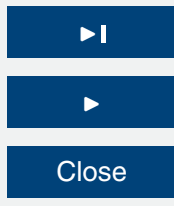

Full Screen / Esc

Printer-friendly Version

Interactive Discussion 
Table 3. Average concentration and standard deviation (SD) of $\mathrm{OC}$ (in $\mu \mathrm{g} \mathrm{cm}^{-2}$ ) in blank quartz filters. All filters are $47 \mathrm{~mm}$ diameter, except those marked with ${ }^{a}$, which had a diameter of $150 \mathrm{~mm}$.

\begin{tabular}{lllllll}
\hline$N$ & \multicolumn{3}{c}{ OC } & \multicolumn{3}{l}{ Pre-firing Filter } \\
& $\mu \mathrm{gcm}^{-2}$ & $\mathrm{SD}$ & $T$ & Time & Brand and Type & Reference \\
\hline 73 & 0.062 & 0.064 & 900 & $3 \mathrm{~h}$ & Pall 2500 QAT UP & Flanagan et al. (2002) \\
72 & 0.148 & 0.095 & 900 & $3 \mathrm{~h}$ & Pall 2500 QAT UP & Flanagan et al. (2002) \\
55 & 0.126 & 0.106 & 900 & $3 \mathrm{~h}$ & Pall 2500 QAT UP & Flanagan et al. (2002) \\
73 & 0.130 & 0.095 & 900 & $3 \mathrm{~h}$ & Pall 2500 QAT UP & Flanagan et al. (2002) \\
78 & 0.121 & 0.096 & 900 & $3 \mathrm{~h}$ & Pall 2500 QAT UP & Flanagan et al. (2002) \\
- & 0.15 & 0.15 & 900 & $3 \mathrm{~h}$ & Pall 2500 QAT UP & Chow et al. (2010) \\
- & 0.1 & 0.15 & 900 & $3 \mathrm{~h}$ & Whatman QM-A & Chow et al. (2010) \\
8 & 0.1 & 0.09 & 650 & $4 \mathrm{~h}$ & Pall 2500 QAT UP & Olson and Norris (2005) \\
14 & 0.45 & & 550 & $24 \mathrm{~h}$ & Pall 2500 QAT UP & Cheng et al. (2009a). \\
9 & 0.22 & 0.11 & 600 & $2 \mathrm{~h}$ & Pall 2500 QAT UP & Chai et al. (2012) \\
9 & 0.38 & 0.06 & NO & & Pall 2500 QAT UP & Chai et al. (2012) \\
& 2.4 & & NO & & Whatman QM-A & ten Brink et al. (2009) \\
128 & 0.797 & 0.395 & 200 & & Pall 2500 QAT UP & IDAEA CSIC \\
127 & 1.22 & 1.11 & NO & & Whatman QM H ${ }^{\mathrm{a}}$ & IDAEA CSIC \\
\hline
\end{tabular}

\section{Measurement of elemental carbon (EC) and organic carbon (OC)}

A. Karanasiou et al.

\section{Title Page}

Abstract

Introduction

Conclusions

References

Tables

Figures

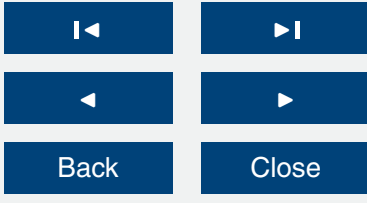

Full Screen / Esc

Printer-friendly Version

Interactive Discussion 
Table 4. Summary of the results regarding the quantification of positive and negative sampling artifacts from the studies found in the course of this literature review.

\begin{tabular}{|c|c|c|c|c|}
\hline Location & Negative artifact & Positive artifact & Comments & Reference \\
\hline California & $50 \%$ of $\mathrm{OC}$ & & $\begin{array}{l}\text { Positive artifact underesti- } \\
\text { mated by } 3.7 \% \text { due to lack } \\
\text { of gas-phase equilibrium }\end{array}$ & Appel et al. (1983) \\
\hline Portland, Oregon (USA) & & $20-50 \%$ of OC & & $\begin{array}{l}\text { McDow \& Huntzicker } \\
\text { (1990) }\end{array}$ \\
\hline $\begin{array}{l}4 \text { US sites (Portland, } \\
\text { Glendora, Meadview, } \\
\text { LookRock) }\end{array}$ & & $10-55 \%$ of OC & & Turpin et al. (2000) \\
\hline ACE-Asia campaign & & $20-100 \%$ of OC & & Mader et al. (2003) \\
\hline Tokyo (Japan) & & $30 \%$ of TC & & $\begin{array}{l}\text { Matsumoto } \\
\text { et al. (2003) }\end{array}$ \\
\hline Vancouver (Canada) & & $18-37 \%$ of OC & $\begin{array}{l}18 \% \text { during night, } 37 \% \\
\text { during day }\end{array}$ & Fan et al. (2004) \\
\hline Budapest (Hungary) & & $10 \pm 16 \%$ of $\mathrm{PM}_{10}$ & & Salma et al. (2004) \\
\hline $\begin{array}{l}\text { Pittsburg, Pennsylvania } \\
\text { (USA) }\end{array}$ & $\begin{array}{l}<10 \% \text { of } \mathrm{OC} \\
\text { with denuder }\end{array}$ & $\begin{array}{l}0.5 \mu \mathrm{gm}^{-3} \quad \text { without } \\
\text { denuder }\end{array}$ & $\begin{array}{l}\text { Constant positive artifact } \\
\text { regardless of the season }\end{array}$ & $\begin{array}{l}\text { Subramanian } \\
\text { et al. (2004) }\end{array}$ \\
\hline Ghent (Belgium) & & $10-20 \%$ of $\mathrm{PM}_{2.5}$ & $\begin{array}{l}\text { Resulting from positive ar- } \\
\text { tifacts, both organic and in- } \\
\text { organic }\end{array}$ & Viana et al. (2006a) \\
\hline Barcelona (Spain) & & $11-16 \%$ of OC & $\begin{array}{l}\text { Sampling artifacts for } \mathrm{OC} \\
\text { were slightly higher in sum- } \\
\text { mer. }\end{array}$ & Viana et al. (2006b) \\
\hline Barcelona (Spain) & & $3 \%$ of $\mathrm{PM}_{2.5}$ & & Viana et al. (2006b) \\
\hline Budapest (Hungary) & & $28 \%$ of WSOC & & Salma et al. (2007) \\
\hline Budapest (Hungary) & & $17 \%$ of HULIS & & Salma et al. (2007) \\
\hline Budapest (Hungary) & & $17 \%$ of $\mathrm{OC}$ & & Salma et al. (2007) \\
\hline $\begin{array}{l}\text { Barcelona (Spain), } \\
\text { Ghent (Belgium, Am- } \\
\text { sterdam (the Nether- } \\
\text { lands) }\end{array}$ & & $\begin{array}{l}11-16 \% \text { of } \mathrm{OC} \text { in } \\
\text { Barcelona; } 5-12 \% \text { of } \\
\mathrm{OC} \text { in Amsterdam; } 5- \\
7 \% \text { of } \mathrm{OC} \text { in Ghent }\end{array}$ & & Viana et al. (2007) \\
\hline $\begin{array}{l}\text { Barcelona (Spain), } \\
\text { Ghent (Belgium, Am- } \\
\text { sterdam (the Nether- } \\
\text { lands) }\end{array}$ & & $1-3 \%$ of $\mathrm{PM}_{2.5}$ & $\begin{array}{l}\text { Impact on mean daily } \\
\mathrm{PM}_{2.5} \text { mass concentrations }\end{array}$ & Viana et al. (2007) \\
\hline $\begin{array}{l}\text { IMPROVE, SEARCH } \\
\text { and STN networks } \\
\text { (USA) }\end{array}$ & $50 \%$ of $\mathrm{OC}$ & $30-50 \%$ of OC & & Watson et al. (2007) \\
\hline
\end{tabular}

AMTD

8, 9649-9712, 2015

\section{Measurement of elemental carbon (EC) and organic carbon (OC)}

A. Karanasiou et al.

\section{Title Page}

Abstract

Introduction

Conclusions

References

Tables

Figures

14

4

Back

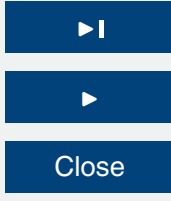

Full Screen / Esc

Printer-friendly Version

Interactive Discussion 
Table 4. Continued.

\begin{tabular}{|c|c|c|c|c|}
\hline Location & Negative artifact & Positive artifact & Comments & Reference \\
\hline $\begin{array}{l}\text { IMPROVE, SEARCH } \\
\text { and STN networks } \\
\text { (USA) }\end{array}$ & & $21.7 \%$ of $\mathrm{PM}_{2.5}$ & & Watson et al. (2007) \\
\hline Beijing (China) & $6-50 \%$ of $\mathrm{OC}$ & & & Cheng et al. (2009a) \\
\hline Beijing (China) & & $10 \%$ of $\mathrm{OC}$ & $\begin{array}{l}\text { TOT-split-EC underesti- } \\
\text { mated native EC by } 21 \\
\text { and } 28 \% \text {, for denuded } \\
\text { and un-denuded samples, } \\
\text { respectively. }\end{array}$ & Cheng et al. (2009b) \\
\hline $\begin{array}{l}\text { the Netherlands, na- } \\
\text { tional BOP programme }\end{array}$ & & $1 \mu \mathrm{gm}^{-3}$ & $\begin{array}{l}\text { The artifact was constant } \\
\text { and thus independent of } \\
\text { season and site. }\end{array}$ & ten Brink et al. (2009) \\
\hline Milano (Italy) & & $23-39 \%$ of OC & $\begin{array}{l}39 \% \text { in summer, } 23 \% \text { in } \\
\text { winter }\end{array}$ & Vecchi et al. (2009) \\
\hline $\begin{array}{l}\text { US networks } \\
\text { IMPROVE, SEARCH } \\
\text { and STN }\end{array}$ & & $5-30 \%$ of OC & & Chow et al. (2010) \\
\hline $\begin{array}{l}\text { Dar es Salaam (Tanza- } \\
\text { nia) }\end{array}$ & & $\begin{array}{l}1 \text { to } 9 \% \text { of } \mathrm{PM}_{2.5} \\
\text { mass }\end{array}$ & & Mkoma et al. (2010) \\
\hline $\begin{array}{l}\text { Dar es Salaam (Tanza- } \\
\text { nia) }\end{array}$ & & $5-8 \%$ of $\mathrm{OC}$ in $\mathrm{PM}_{2.5}$ & $\begin{array}{l}\text { Little difference between } \\
\text { dry and wet seasons }\end{array}$ & Mkoma et al. (2010) \\
\hline $\begin{array}{l}\text { Dar es Salaam (Tanza- } \\
\text { nia) }\end{array}$ & & $6-7 \%$ of $\mathrm{OC}$ in $\mathrm{PM}_{10}$ & $\begin{array}{l}\text { Little difference between } \\
\text { dry and wet seasons }\end{array}$ & Mkoma et al. (2010) \\
\hline Ghent (Belgium) & & $6-19 \%$ of $\mathrm{OC}$ in $\mathrm{PM}_{2}$ & Without denuder & Mikuška et al. (2012) \\
\hline Ghent (Belgium) & $\begin{array}{l}-4-7 \% \text { of } \mathrm{OC} \text { in } \\
\mathrm{PM}_{2} \text {. }\end{array}$ & & With denuder & Mikuška et al. (2012) \\
\hline Europe (forested sites) & & $\begin{array}{l}13-18 \% \text { of } \mathrm{OC} \text { in } \\
\mathrm{PM}_{2} \text {. }\end{array}$ & Without denuder & Mikuška et al. (2012) \\
\hline Europe (forested sites) & $\begin{array}{l}2-5 \% \text { of } \mathrm{OC} \text { in } \\
\mathrm{PM}_{2} \text {. }\end{array}$ & & With denuder & Mikuška et al. (2012) \\
\hline $\begin{array}{l}\text { EUSAAR sites (regional } \\
\text { background) }\end{array}$ & & $14-70 \%$ of TC & Without denuder & EUSAAR (2011) \\
\hline $\begin{array}{l}\text { EUSAAR sites (regional } \\
\text { background) }\end{array}$ & & $1-21 \%$ of TC & With denuder & EUSAAR (2011) \\
\hline Ispra (Italy) & $5.4 \pm 2.1 \%$ of $\mathrm{OC}$ & & & EUSAAR (2011) \\
\hline $\begin{array}{l}\text { STN/IMPROVE, PAQS } \\
\text { and RIOPA studies }\end{array}$ & & $15-34 \%$ of OC & PAQS sites & $\begin{array}{l}\text { Maimone } \\
\text { et al. (2011) }\end{array}$ \\
\hline $\begin{array}{l}\text { STN/IMPROVE, PAQS } \\
\text { and RIOPA studies }\end{array}$ & & $31-43 \%$ of OC & RIOPA sites & $\begin{array}{l}\text { Maimone } \\
\text { et al. (2011) }\end{array}$ \\
\hline Beijing (China) & & $15 \%$ of $\mathrm{OC}$ & & Cheng Y. et al. (2012) \\
\hline $\begin{array}{l}\text { Xueshan Tunnel (Tai- } \\
\text { wan) }\end{array}$ & & $48 \%$ of $\mathrm{PM}_{0.1}$ & & Zhu et al. (2012) \\
\hline
\end{tabular}

\section{Measurement of elemental carbon (EC) and organic carbon (OC)}

A. Karanasiou et al.

\section{Title Page}

Abstract

Introduction

Conclusions

References

Tables

Figures

14

4

Back

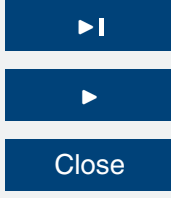

Full Screen / Esc

Printer-friendly Version

Interactive Discussion 
Table 5. Comparison of TOT and TOR. The slope of the linear regression between EC concentrations determined using TOR vs. those using TOR is given.

\begin{tabular}{|c|c|c|c|c|c|c|}
\hline Site & Analyzer & $\begin{array}{l}\text { IMPROVE_A } \\
\text { (Tmax) }\end{array}$ & $\begin{array}{l}\mathrm{NIOSH} \\
(\text { Tmax })\end{array}$ & EUSAAR_2 & slope TOR TOT & Reference \\
\hline $\begin{array}{lrl}9 & \mathrm{PM}_{2.5} & \text { non-urban } \\
\text { samples, } & \text { IMPROVE } \\
\text { Network } & \end{array}$ & DRI & $\begin{array}{l}\text { IMPROVE } \\
\left(550^{\circ} \mathrm{C}\right)\end{array}$ & $\begin{array}{l}\mathrm{NIOSH} \\
\left(850^{\circ} \mathrm{C}\right)\end{array}$ & & $\begin{array}{l}1.0-2.0 \text { (IMPROVE) } \\
1.0-3.5 \text { (NIOSH) }\end{array}$ & Chow et al. (2001) \\
\hline $\begin{array}{l}13 \mathrm{PM}_{2.5} \text { urban sam- } \\
\text { ples, Mexico }\end{array}$ & DRI & $\begin{array}{l}\text { IMPROVE } \\
\left(550^{\circ} \mathrm{C}\right)\end{array}$ & $\begin{array}{l}\mathrm{NIOSH} \\
\left(850^{\circ} \mathrm{C}\right)\end{array}$ & & $\begin{array}{l}1.2-1.9(\text { IMPROVE) } \\
1 \text { (NIOSH) }\end{array}$ & Chow et al. (2001) \\
\hline $\begin{array}{lr}30 \quad \mathrm{PM}_{2.5} & \text { samples } \\
\text { Fresno } & \text { California, } \\
\text { USA } & \end{array}$ & DRI & $\begin{array}{l}\text { LowT } \\
\left(550^{\circ} \mathrm{C}\right)\end{array}$ & $\begin{array}{l}\text { HighT } \\
\left(800^{\circ} \mathrm{C}\right)\end{array}$ & & $\begin{array}{l}1.4 \text { (LowT) } \\
2.5 \text { (HighT) }\end{array}$ & Chow et al. (2004) \\
\hline $\begin{array}{l}10 \mathrm{PM}_{2.5} \text { Pittsburgh, } \\
\text { USA }\end{array}$ & Sunset & $\begin{array}{l}\mathrm{He} 4-550 \\
\left(550^{\circ} \mathrm{C}\right)\end{array}$ & $\begin{array}{l}\mathrm{He} 4- \\
700 \\
\left(700^{\circ} \mathrm{C}\right)\end{array}$ & & $\begin{array}{l}1.9(\mathrm{He} 4-550) \\
2.2(\mathrm{He} 4-700)\end{array}$ & $\begin{array}{l}\text { Subramanian } \\
\text { et al. (2006) }\end{array}$ \\
\hline $\begin{array}{l}\mathrm{PM}_{2.5} \text { Fresno Califor- } \\
\text { nia, USA }\end{array}$ & DRI & $\begin{array}{l}\text { IMPROVE_A } \\
\left(580^{\circ} \mathrm{C}\right)\end{array}$ & & & 1.2 & Chow et al. (2009) \\
\hline $\mathrm{PM}_{2.5}$, Beijing, China & DRI & $\begin{array}{l}\text { IMPROVE_A } \\
\left(580^{\circ} \mathrm{C}\right)\end{array}$ & & & $\begin{array}{l}1.8 \text { (denuded sam- } \\
\text { ples) } \\
1.9 \text { (undenuded sam- } \\
\text { ples) }\end{array}$ & Cheng et al. (2010) \\
\hline $\begin{array}{lrl}10 & \mathrm{PM}_{2.5} \text { Amazon } \\
\text { Basin, Brasil }\end{array}$ & DRI & $\begin{array}{l}\text { IMPROVE_A } \\
\left(580^{\circ} \mathrm{C}\right)\end{array}$ & & & 2.0 & $\begin{array}{l}\text { Soto-Garcia } \\
\text { et al. (2011) }\end{array}$ \\
\hline $\mathrm{PM}_{2.5}$, Beijing, China & DRI & $\begin{array}{l}\text { IMPROVE_A } \\
\left(580^{\circ} \mathrm{C}\right)\end{array}$ & & & $0.9-2.2$ & Cheng et al. (2011) \\
\hline $\begin{array}{l}70 \mathrm{PM}_{10} \text { samples from } \\
\text { Flanders, Belgium }\end{array}$ & Sunset & & $\begin{array}{l}\mathrm{NIOSH} \\
\left(900^{\circ} \mathrm{C}\right)\end{array}$ & EUSAAR_2 & $\begin{array}{l}1.5 \text { (EUSAAR_2) } \\
1.7 \text { (NIOSH) }\end{array}$ & $\begin{array}{l}\text { Maenhaut } \\
\text { et al. (2012) }\end{array}$ \\
\hline $\begin{array}{l}\mathrm{PM}_{2.5} \text { urban samples } \\
\text { China }\end{array}$ & Sunset & $\begin{array}{l}\text { IMPROVE_A } \\
\left(580^{\circ} \mathrm{C}\right)\end{array}$ & $\begin{array}{l}\text { ACE- } \\
\text { Asia } \\
\left(870^{\circ} \mathrm{C}\right)\end{array}$ & & $\begin{array}{l}\text { 3.4(IMPROVE_A) } \\
\text { 3.1 (ACE-Asia) }\end{array}$ & Wu et al. (2012) \\
\hline $\begin{array}{l}\mathrm{PM}_{2.5} \text { urban samples } \\
\text { China }\end{array}$ & DRI & $\begin{array}{l}\text { IMPROVE_A } \\
\left(580^{\circ} \mathrm{C}\right)\end{array}$ & $\begin{array}{l}\text { ACE- } \\
\text { Asia } \\
\left(870^{\circ} \mathrm{C}\right)\end{array}$ & & $\begin{array}{l}\text { 2.6(IMPROVE_A) } \\
\text { 3.4 (ACE-Asia) }\end{array}$ & Wu et al. (2012) \\
\hline $\begin{array}{l}245 \mathrm{PM}_{10} \text { urban sam- } \\
\text { ples France } \\
128 \mathrm{PM}_{10} \text { and } \mathrm{PM}_{2.5} \\
\text { urban and rural sam- } \\
\text { ples Belgium, } \\
325 \mathrm{PM}_{2.5} \text { rural sam- } \\
\text { ples, Ispra Italy }\end{array}$ & Sunset & & $\begin{array}{l}\mathrm{NIOSH} \\
\left(850^{\circ} \mathrm{C}\right)\end{array}$ & EUSAAR_2 & $\begin{array}{l}1.3 \text { (EUSAAR_2) } \\
\text { all samples } \\
1.4 \text { (EUSAAR_2) } \\
\text { urban samples } \\
1.8 \text { (EUSAAR_2) } \\
\text { rural samples } \\
1.3 \text { (NIOSH) } \\
\text { all samples } \\
1.2 \text { (NIOSH) } \\
\text { urban samples } \\
2.1 \text { (NIOSH) } \\
\text { rural samples }\end{array}$ & $\begin{array}{l}\text { Chiappini } \\
\text { et al. (2014) }\end{array}$ \\
\hline
\end{tabular}
The difference between NIOSH EC-TOR and EC-TOT was often zero because reflectance and transmittance returned to their initial values prior to the addition of
oxygen for many of the samples during the $850^{\circ} \mathrm{C}$ step of the analysis.

\section{AMTD}

8, 9649-9712, 2015

\section{Measurement of elemental carbon (EC) and organic carbon (OC)}

A. Karanasiou et al.

\section{Title Page}

Abstract

Introduction

Conclusions

References

Tables

Figures

14

4

Back

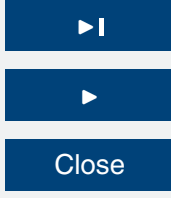

Full Screen / Esc

Printer-friendly Version

Interactive Discussion 
Table 6. Comparison of thermal-optical protocols. The slope of the regression of EC between two different protocols is given.

\begin{tabular}{|c|c|c|c|c|c|c|c|}
\hline Site & Analyzer & $\begin{array}{l}\text { Optical Correc- } \\
\text { tion }\end{array}$ & IMPROVE_A & $\mathrm{NIOSH}$ & EUSAAR_2 & Slope EC & Reference \\
\hline $\begin{array}{l}41 \quad \mathrm{PM}_{2.5} \text { IMPROVE, } \\
\text { USA } \\
19 \text { source samples }\end{array}$ & DRI & $\begin{array}{l}\text { Transmittance, } \\
\text { Reflectance }\end{array}$ & $\begin{array}{l}\text { IMPROVE } \\
\left(550^{\circ} \mathrm{C}\right)\end{array}$ & $\begin{array}{l}\mathrm{NIOSH} \\
\left(850^{\circ} \mathrm{C}\right)\end{array}$ & & 2.5 (IMPROVE TOR/NIOSH TOT) & $\begin{array}{l}\text { Chow } \\
\text { et al. (2001) }\end{array}$ \\
\hline $\mathrm{PM}_{2.5}$ Toronto, Canada & $\begin{array}{l}\text { DRI, Sun- } \\
\text { set }\end{array}$ & $\begin{array}{l}\text { Transmittance, } \\
\text { Reflectance }\end{array}$ & $\begin{array}{l}\text { IMPROVE } \\
\left(550^{\circ} \mathrm{C}\right)\end{array}$ & $\begin{array}{l}\text { MSC1 } \\
\left(900^{\circ} \mathrm{C}\right)\end{array}$ & & 0.9 (IMPROVE TOR/MSC1 TOT) & $\begin{array}{l}\text { Sharma } \\
\text { et al. (2002) }\end{array}$ \\
\hline $\begin{array}{l}\mathrm{PM}_{2.5} \text { Bakersfield, St. } \\
\text { Louis, USA and source } \\
\text { samples }\end{array}$ & Sunset & Transmittance & $\mathrm{He} 4-550$ & $\begin{array}{l}\text { ACE-Asia } \\
\left(870^{\circ} \mathrm{C}\right) \\
\mathrm{He} 4-750\end{array}$ & $\mathrm{He} 4-650$ & $\begin{array}{l}\text { 1.5 (He4-550/ACE-Asia) } \\
1.2 \text { (He4-550/He4-750) } \\
1.5 \text { (He4-650/ACE-Asia) } \\
2.2^{\mathrm{a}}, 1.1^{\mathrm{b}}, 1.0^{\mathrm{c}} \text { (He4-650/ACE-Asia) }\end{array}$ & $\begin{array}{l}\text { Schauer } \\
\text { et al. (2003) }\end{array}$ \\
\hline $\begin{array}{l}30 \mathrm{PM}_{2.5} \text { samples Fresno } \\
\text { California, USA }\end{array}$ & DRI & $\begin{array}{l}\text { Transmittance, } \\
\text { Reflectance }\end{array}$ & $\begin{array}{l}\text { LowT } \\
\left(550^{\circ} \mathrm{C}\right)\end{array}$ & $\begin{array}{l}\text { HighT } \\
\left(800^{\circ} \mathrm{C}\right)\end{array}$ & & $\begin{array}{l}1.0 \text { (LowT TOR/HighT TOR) } \\
2.2 \text { (LowT TOT/HighT TOT) } \\
3.5 \text { (LowT TOR/HighT TOT) }\end{array}$ & $\begin{array}{l}\text { Chow } \\
\text { et al. (2004) }\end{array}$ \\
\hline $\begin{array}{l}\mathrm{PM}_{2.5} \text { samples Hong } \\
\text { Kong, China }\end{array}$ & $\begin{array}{l}\text { DRI, Sun- } \\
\text { set }\end{array}$ & $\begin{array}{l}\text { Transmittance, } \\
\text { Reflectance }\end{array}$ & $\begin{array}{l}\text { IMPROVE_A } \\
\left(580^{\circ} \mathrm{C}\right)\end{array}$ & $\begin{array}{l}\text { HKGL } \\
\left(850^{\circ} \mathrm{C}\right) \\
\text { STN } \\
\left(900^{\circ} \mathrm{C}\right)\end{array}$ & & $\begin{array}{l}\text { 1.3 (IMPROVE TOR/STN TOR) } \\
1.4 \text { (IMPROVE TOR/HKGL TOT) } \\
0.8 \text { (STN TOT/HKGL TOT) }\end{array}$ & $\begin{array}{l}\text { Chow } \\
\text { et al. (2005a) }\end{array}$ \\
\hline $\mathrm{PM}_{2.5}$ Pittsburgh, USA & Sunset & $\begin{array}{l}\text { Transmittance, } \\
\text { Reflectance }\end{array}$ & $\begin{array}{l}\mathrm{He} 4-550 \\
\left(550^{\circ} \mathrm{C}\right)\end{array}$ & $\begin{array}{l}\mathrm{He} 4-700 \\
\left(700^{\circ} \mathrm{C}\right) \\
\mathrm{He} 4-870 \\
\left(870^{\circ} \mathrm{C}\right)\end{array}$ & & $\begin{array}{l}1.5(\mathrm{He} 4-550 / \mathrm{He} 4-870) \\
1.5(\mathrm{He} 4-550 / \mathrm{He} 4-700) \\
1.3(\mathrm{He} 4-700 / \mathrm{He} 4-870)\end{array}$ & $\begin{array}{l}\text { Subramanian } \\
\text { et al. (2006) }\end{array}$ \\
\hline Crete, Greece & Sunset & Transmittance & $\begin{array}{l}\text { IMPROVE } \\
\left(550^{\circ} \mathrm{C}\right)\end{array}$ & $\begin{array}{l}\mathrm{NIOSH} \\
\left(870^{\circ} \mathrm{C}\right)\end{array}$ & & $1.2(\mathrm{He} 4-550 / \mathrm{He} 4-870)$ & $\begin{array}{l}\text { Sciare } \\
\text { et al. (2008) }\end{array}$ \\
\hline $\mathrm{PM}_{10}$ Vienna, Austria & Sunset & Transmittance & $\begin{array}{l}\text { TOT-A3 (Im- } \\
\text { prove -like } \\
\left(550^{\circ} \mathrm{C}\right)\end{array}$ & $\begin{array}{l}\text { NIOSH } \\
\left(870^{\circ} \mathrm{C}\right)\end{array}$ & & 1.7 (TOT-A3/NIOSH TOT) & $\begin{array}{l}\text { Reisinger } \\
\text { et al. (2008) }\end{array}$ \\
\hline TSP southern Austria & Sunset & Transmittance & $\begin{array}{l}\text { TOT-A3 (Im- } \\
\text { prove -like } \\
\left.\left(550^{\circ} \mathrm{C}\right)\right)\end{array}$ & $\begin{array}{l}\mathrm{NIOSH} \\
\left(900^{\circ} \mathrm{C}\right)\end{array}$ & EUSAAR_2 & $\begin{array}{l}1.5 \text { (TOT-A3/NIOSH TOT) } \\
1.2 \text { (EUSAAR_2/NIOSH TOT) }\end{array}$ & $\begin{array}{l}\text { Maenhaut } \\
\text { et al. (2009) }\end{array}$ \\
\hline $\mathrm{PM}_{2.5}$ Ghent, Belgium & Sunset & Transmittance & $\begin{array}{l}\text { TOT-A3 }(\mathrm{Im}- \\
\text { prove -like } \\
\left.\left(550^{\circ} \mathrm{C}\right)\right)\end{array}$ & $\begin{array}{l}\mathrm{NIOSH} \\
\left(900^{\circ} \mathrm{C}\right)\end{array}$ & EUSAAR_2 & $\begin{array}{l}1.7 \text { (TOT-A3/NIOSH TOT) } \\
1.7 \text { (EUSAAR_2/NIOSH TOT) }\end{array}$ & $\begin{array}{l}\text { Maenhaut } \\
\text { et al. (2009) }\end{array}$ \\
\hline $\begin{array}{l}\mathrm{PM}_{2.5} \text { Amazon basin (dry } \\
\text { season), Brazil }\end{array}$ & Sunset & Transmittance & $\begin{array}{l}\text { TOT-A3 }(\mathrm{Im}- \\
\text { prove -like } \\
\left.\left(550^{\circ} \mathrm{C}\right)\right)\end{array}$ & $\begin{array}{l}\mathrm{NIOSH} \\
\left(900^{\circ} \mathrm{C}\right)\end{array}$ & EUSAAR_2 & $\begin{array}{l}2.9 \text { (TOT-A3/NIOSH TOT) } \\
2.7 \text { (EUSAAR_2/NIOSH TOT) }\end{array}$ & $\begin{array}{l}\text { Maenhaut } \\
\text { et al. (2009) }\end{array}$ \\
\hline TSP Beijing, China & Sunset & Transmittance & $\begin{array}{l}\text { TOT-A3 }(\mathrm{Im}- \\
\text { prove -like } \\
\left.\left(550^{\circ} \mathrm{C}\right)\right)\end{array}$ & $\begin{array}{l}\mathrm{NIOSH} \\
\left(900^{\circ} \mathrm{C}\right)\end{array}$ & EUSAAR_2 & $\begin{array}{l}2.0 \text { (TOT-A3/NIOSH TOT) } \\
1.7 \text { (EUSAAR_2/NIOSH TOT) }\end{array}$ & $\begin{array}{l}\text { Maenhaut } \\
\text { et al. (2009) }\end{array}$ \\
\hline $\begin{array}{l}\mathrm{PM}_{2.5} \text { Fresno California, } \\
\text { USA }\end{array}$ & $\begin{array}{l}\text { DRI/ } \\
\text { Sunset }\end{array}$ & $\begin{array}{l}\text { Transmittance, } \\
\text { Reflectance }\end{array}$ & $\begin{array}{l}\text { IMPROVE_A } \\
\left(580^{\circ} \mathrm{C}\right)\end{array}$ & $\begin{array}{l}\text { STN } \\
\left(900^{\circ} \mathrm{C}\right)\end{array}$ & & 1.3 (IMPROVE_A TOR/STN TOT) & $\begin{array}{l}\text { Chow } \\
\text { et al. (2009) }\end{array}$ \\
\hline
\end{tabular}

AMTD

8, 9649-9712, 2015

Measurement of elemental carbon

(EC) and organic carbon (OC)

A. Karanasiou et al.

Title Page

Abstract

Introduction

Conclusions References

Tables

Figures

14

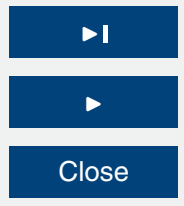

Full Screen / Esc

Printer-friendly Version

Interactive Discussion 
Table 6. Continued.

\begin{tabular}{|c|c|c|c|c|c|c|c|}
\hline Site & Analyzer & $\begin{array}{l}\text { Optical Correc- } \\
\text { tion }\end{array}$ & IMPROVE_A & $\mathrm{NIOSH}$ & EUSAAR_2 & Slope EC & Reference \\
\hline $\mathrm{PM}_{2.5}$, Beijing, China & DRI & $\begin{array}{l}\text { Transmittance, } \\
\text { Reflectance }\end{array}$ & $\begin{array}{l}\text { IMPROVE_A } \\
\left(580^{\circ} \mathrm{C}\right)\end{array}$ & $\begin{array}{l}\mathrm{He} 4-800 \\
\left(800^{\circ} \mathrm{C}\right)\end{array}$ & & $1.9,2.0^{d}$ (IMPROVE_A/He4-800) & $\begin{array}{l}\text { Cheng } \\
\text { et al. (2010) }\end{array}$ \\
\hline $\begin{array}{l}26 \mathrm{PM}_{10} \text { urban back- } \\
\text { ground, Milan, Italy }\end{array}$ & Sunset & Transmittance & $\begin{array}{l}\text { IMPROVE_A } \\
\left(580^{\circ} \mathrm{C}\right)\end{array}$ & $\begin{array}{l}\mathrm{NIOSH} \\
\left(870^{\circ} \mathrm{C}\right)\end{array}$ & EUSAAR_2 & $\begin{array}{l}1.5,1.2^{\mathrm{e}} \text { (EUSAAR_2 TOT/NIOSH TOT) } \\
1.6,1.4^{\mathrm{e}} \text { (IMPROVE_A TOT/NIOSH } \\
\text { TOT) } \\
1.1,1.1^{\mathrm{e}} \text { (IMPROVE_A TOT/EUSAAR_2 } \\
\text { TOT) }\end{array}$ & $\begin{array}{l}\text { Piazzalunga } \\
\text { et al. (2011) }\end{array}$ \\
\hline $\begin{array}{l}\mathrm{PM}_{2.5} \text { Amazon Basin, } \\
\text { Brasil }\end{array}$ & $\begin{array}{l}\text { DRI, Sun- } \\
\text { set }\end{array}$ & $\begin{array}{l}\text { Transmittance, } \\
\text { Reflectance }\end{array}$ & $\begin{array}{l}\text { IMPROVE_A } \\
\left(580^{\circ} \mathrm{C}\right)\end{array}$ & $\mathrm{NIOSH}$ & & > 3 (IMPROVE_A/NIOSH) & $\begin{array}{l}\text { Soto- } \\
\text { Garcia } \\
\text { et al. (2011) }\end{array}$ \\
\hline $\begin{array}{l}\text { urban and source sam- } \\
\text { ples from multiple sites, } \\
\text { China }\end{array}$ & $\begin{array}{l}\text { DRI, Sun- } \\
\text { set }\end{array}$ & $\begin{array}{l}\text { Transmittance, } \\
\text { Reflectance }\end{array}$ & $\begin{array}{l}\text { IMPROVE_A } \\
\left(580^{\circ} \mathrm{C}\right)\end{array}$ & $\begin{array}{l}\mathrm{NIOSH} \\
\left(850^{\circ} \mathrm{C}\right)\end{array}$ & & 2 (IMPROVE_A TOR/NIOSH TOT) & $\begin{array}{l}\text { Zhi } \\
\text { et al. (2011) }\end{array}$ \\
\hline $\mathrm{PM}_{2.5}$ Beijing, China & DRI & Transmittance & $\begin{array}{l}\text { IMPROVE_A } \\
\left(580^{\circ} \mathrm{C}\right)\end{array}$ & $\begin{array}{l}\text { IMCAS } \\
\left(850^{\circ} \mathrm{C}\right)\end{array}$ & $\begin{array}{l}\text { EU similar } \\
\text { to } \quad \text { EU- } \\
\text { SAAR_2 } \\
\left(650^{\circ} \mathrm{C}\right)\end{array}$ & $\begin{array}{l}2.0 \text { (IMPROVE_A/IMCAS) } \\
1.2 \text { (IMPROVE_A/EUSAAR_2) }\end{array}$ & $\begin{array}{l}\text { Cheng W. } \\
\text { et al. (2012) }\end{array}$ \\
\hline $\begin{array}{l}\mathrm{PM}_{10} \text { samples from } 7 \\
\text { sites in Flanders, Belgium }\end{array}$ & Sunset & $\begin{array}{l}\text { Transmittance, } \\
\text { Reflectance }\end{array}$ & & $\begin{array}{l}\mathrm{NIOSH} \\
\left(900^{\circ} \mathrm{C}\right)\end{array}$ & EUSAAR_2 & 1.3 (EUSAAR_2 TOT/NIOSH TOT) & $\begin{array}{l}\text { Maenhaut } \\
\text { et al. (2012) }\end{array}$ \\
\hline $\begin{array}{l}\mathrm{PM}_{2.5} \text { rural samples } \\
\text { North Carolina USA, } \\
\text { TSP Nairobi, Kenya } \\
\text { diesel exhaust, } \\
\text { cookstove samples }\end{array}$ & Sunset & $\begin{array}{l}\text { Transmittance, } \\
\text { Reflectance }\end{array}$ & $\begin{array}{l}\text { IMPROVE } \\
\left(580^{\circ} \mathrm{C}\right)\end{array}$ & $\begin{array}{l}\text { NIST-EPA } \\
\left(785^{\circ} \mathrm{C}\right) \\
\text { NIOSH } \\
\left(870^{\circ} \mathrm{C}\right)\end{array}$ & & $\begin{array}{l}1.3^{\mathrm{f}} 2.9^{\mathrm{g}}, 1.5^{\mathrm{h}}, \\
1.5^{\mathrm{f}} \text { (IMPROVE TOR/NIOSH TOT) }\end{array}$ & $\begin{array}{l}\text { Khan } \\
\text { et al. (2012) }\end{array}$ \\
\hline $\begin{array}{l}\mathrm{PM}_{2.5} \text { multiple sites, } \\
\text { China }\end{array}$ & $\begin{array}{l}\text { DRI, Sun- } \\
\text { set }\end{array}$ & $\begin{array}{l}\text { Transmittance, } \\
\text { Reflectance }\end{array}$ & $\begin{array}{l}\text { IMPROVE_A } \\
\left(580^{\circ} \mathrm{C}\right)\end{array}$ & $\begin{array}{l}\text { ACE-Asia } \\
\left(870^{\circ} \mathrm{C}\right)\end{array}$ & & $\begin{array}{llll}1.8^{j} & 1.7^{\mathrm{k}} & \text { (IMPROVE } & \text { TOR/ACE-Asia } \\
\text { TOR) } & & & \\
1.6^{\dagger}, & 1.6^{\mathrm{h}} & \text { (IMPROVE } & \text { TOT/ACE-Asia } \\
\text { TOT) } & & & \\
5.4^{\mathrm{j}}, & 4.3^{\mathrm{k}} & \text { (IMPROVE } & \text { TOR/ACE-Asia } \\
\text { TOT) } & & & \end{array}$ & $\begin{array}{l}\text { Wu } \\
\text { et al. (2012) }\end{array}$ \\
\hline $\mathrm{PM}_{2.5}$ Beijing, China & $\begin{array}{l}\text { DRI, Sun- } \\
\text { set }\end{array}$ & Transmittance & $\begin{array}{l}\text { IMPROVE_A } \\
\left(580^{\circ} \mathrm{C}\right)\end{array}$ & $\begin{array}{l}\mathrm{NIOSH} \\
\left(870^{\circ} \mathrm{C}\right)\end{array}$ & EUSAAR_2 & $\begin{array}{l}\text { 1.3 (IMPROVE_A/NIOSH) } \\
0.9 \text { (IMPROVE_A/EUSAAR_2) }\end{array}$ & $\begin{array}{l}\text { Cheng } \\
\text { et al. (2014) }\end{array}$ \\
\hline
\end{tabular}

a Wood smoke samples.

b Coal fly ash samples.
${ }^{\mathrm{C}}$ Carbon black samples.

Calculated when denuders were used.

Calculated after removal of water-soluble organic compounds, wSOC

TSP urban samples.

${ }^{9} \mathrm{PM}_{2.5}$ rural samples.

Diesel exhaust samples.

Cookstove samples.

Calculated using the Sunset analyzer.

Calculated using the DRI analyzer.
TOT: thermal-optical transmission.

TOR: thermal-optical reflectance.
AMTD

8, 9649-9712, 2015

\section{Measurement of elemental carbon \\ (EC) and organic carbon (OC)}

A. Karanasiou et al.

\section{Title Page}

Abstract

Introduction

Conclusions References

Tables

Figures

14

4

Back

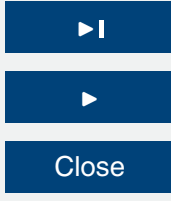

Full Screen / Esc

Printer-friendly Version

Interactive Discussion 
Table 7. Inter-laboratory comparisons using thermal-optical methods for the determination of $\mathrm{EC}, \mathrm{OC}$ and TC concentrations. Number of laboratories participating, number of samples analyzed, protocols used, range of concentrations and relative standard deviation (RSD) for each carbonaceous fraction.

\begin{tabular}{|c|c|c|c|c|c|c|c|c|c|c|c|}
\hline Study & $\mathrm{n}$ labs & $\mathrm{n}$ samples & Protocols & $\begin{array}{l}\text { Range EC } \\
\mu \mathrm{g} \mathrm{cm}^{-2}\end{array}$ & $\begin{array}{l}\text { Range OC } \\
\mu \mathrm{g} \mathrm{cm}^{-2}\end{array}$ & $\begin{array}{l}\text { Range TC } \\
\mu \mathrm{g} \mathrm{cm}^{-2}\end{array}$ & $\begin{array}{l}\text { Range } \\
\text { EC/TC }\end{array}$ & RSD EC (\%) & RSD OC (\%) & $\begin{array}{l}\text { RSD TC } \\
(\%)\end{array}$ & $\begin{array}{l}\text { RSD } \\
\text { EC/TC } \\
(\%)\end{array}$ \\
\hline Birch (1998) & 5 & 5 & NIOSH5040 & $0.3-16.1$ & $10.4-139.8$ & & & $6-26^{a}$ & $3-7$ & & \\
\hline Schmid et al. (2001) & 5 & 3 & $\begin{array}{l}\text { TLT } \\
\text { TOT } \\
\text { TOR }\end{array}$ & $21-518$ & & $32-150$ & & $26-48$ & & $6-7$ & \\
\hline $\begin{array}{l}\text { Birch (2002) } \\
\text { Birch et al. (1999) }\end{array}$ & 3 & 50 & $\mathrm{NIOSH} 5040$ & & & & & 10 & 12 & 6 & \\
\hline EUSAAR (2007) & $\begin{array}{l}12^{f} \\
10^{g}\end{array}$ & $\begin{array}{l}8^{f} \\
7^{g}\end{array}$ & $\begin{array}{l}\text { NIOSH } \\
\text { quartz } \\
\text { EUSAAR_1 } \\
\text { IMPROVE } \\
\text { others }\end{array}$ & $2-9$ & $3-60$ & $3-75$ & & $40^{\mathrm{h}} 13^{\mathrm{i}} 29^{\mathrm{j}}$ & 15 & 11 & \\
\hline EUSAAR (2008) & $\begin{array}{l}13^{\mathrm{fk}}, g^{\mathrm{fl}} \\
11^{\mathrm{k}^{\mathrm{g}}}, 8^{\mathrm{g}^{\mathrm{g}}}\end{array}$ & 6 & $\begin{array}{l}\text { NIOSH } \\
\text { EUSAAR_2 }\end{array}$ & $0.3-3$ & & $5-45$ & $0.03-0.14$ & & & $17^{k} 20^{\prime}$ & $\begin{array}{l}30^{\mathrm{km}} 36^{\mathrm{lm}} \\
48^{\mathrm{n}}\end{array}$ \\
\hline EUSAAR (2011) & 3 & $\begin{array}{l}27 \\
5 \text { blks } \\
4 \text { NIST } 8785\end{array}$ & $\begin{array}{l}\text { EnvCan } \\
\text { IMPROVE_A } \\
\text { EUSAAR_2 }\end{array}$ & $\begin{array}{l}<\mathrm{DL}-1.5 \\
\mu \mathrm{gm}^{-3}\end{array}$ & & $0.5-7 \mu \mathrm{gm}^{-3}$ & & $25^{b}$ & & $10^{c}$ & \\
\hline
\end{tabular}

\section{Measurement of elemental carbon (EC) and organic carbon (OC)}

A. Karanasiou et al.

\section{Title Page}

Abstract

Introduction

Conclusions

References

Tables

Figures

14

4

Back

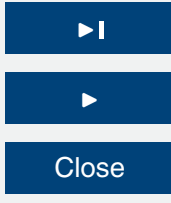

Full Screen / Esc

Printer-friendly Version

Interactive Discussion 
Table 7. Contiuned.

\begin{tabular}{|c|c|c|c|c|c|c|c|c|c|c|c|}
\hline Study & n labs & $\mathrm{n}$ samples & Protocols & $\begin{array}{l}\text { Range EC } \\
\mu \mathrm{g} \mathrm{cm}^{-2}\end{array}$ & 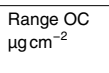 & $\begin{array}{l}\text { Range TC } \\
\mu \mathrm{g} \mathrm{cm}^{-2}\end{array}$ & $\begin{array}{l}\text { Range } \\
\text { EC/TC }\end{array}$ & RSD EC (\%) & RSD OC (\%) & $\begin{array}{l}\text { RSD TC } \\
(\%)\end{array}$ & $\begin{array}{l}\text { RSD } \\
\text { EC/TC } \\
(\%)\end{array}$ \\
\hline ACTRIS (2011) & 18 & 6 & $\begin{array}{l}\text { EUSAAR_2 } \\
\text { quartz } \\
\text { NIOSH }\end{array}$ & & & $8.1-36.4$ & $0.01-0.11$ & & & $13-27^{c}$ & $12-33^{c}$ \\
\hline Chai et al. (2012) & 7 & 4 & $\mathrm{NIOSH} 5040$ & $8-14$ & $10-17$ & $20-27$ & & $7-9$ & $7-10$ & $5-9$ & \\
\hline $\begin{array}{l}\text { Emblico et al. (2012) } \\
\text { (AQUILA, 1st interc.) }\end{array}$ & $\begin{array}{l}16,6^{m}, \\
11^{n},\end{array}$ & 14 & $\begin{array}{l}\text { EUSAAR_2 } \\
\text { NIOSH } \\
\text { (transmittance) }\end{array}$ & $\begin{array}{l}4-14^{\mathrm{m}} \\
3-9^{\mathrm{n}} \\
\text { (excl. blk) }\end{array}$ & $1.4-65$ & $1.5-76$ & & $\begin{array}{l}10-25^{m} \\
10-24^{n}\end{array}$ & $\begin{array}{l}5-11^{\mathrm{mr}} \\
4-9^{\mathrm{nr}}\end{array}$ & $4-7^{s}$ & \\
\hline $\begin{array}{l}\text { Chiappini } \\
\text { et al. (2014) }\end{array}$ & 5 & $\begin{array}{l}\text { 3, (N1, N2, } \\
\text { N3) }\end{array}$ & $\begin{array}{l}\text { NIOSH5040 } \\
\text { EUSAAR_2 } \\
\text { (transmittance, } \\
\text { reflectance) }\end{array}$ & $4.73-23.02$ & $11.98-52.67$ & $17.41-72.04$ & $0.25-0.49$ & $\begin{array}{l}\text { N1:6.8 } \\
\text { N2:19.2 } \\
\text { N3:10 }\end{array}$ & $\begin{array}{l}9.6 \\
9.1 \\
4.8\end{array}$ & $\begin{array}{l}6.9 \\
4.6 \\
3.2\end{array}$ & $\begin{array}{l}9.7 \\
20.3 \\
10.1\end{array}$ \\
\hline $\begin{array}{l}\text { Panteliadis } \\
\text { et al. (2013) and } \\
2015\end{array}$ & 17 & 5 & $\begin{array}{l}\text { EUSAAR_2 } \\
\text { NIOSH-870 }\end{array}$ & $1-14$ & & $8-80$ & & $\begin{array}{l}20^{\mathrm{cm}} \\
26^{\mathrm{cn}}\end{array}$ & & $\begin{array}{l}15^{\mathrm{cm}} \\
12^{\mathrm{cn}}\end{array}$ & \\
\hline
\end{tabular}

a For samples with avg above $0.3 \mathrm{\mu gcm}^{-2}$ of EC.

b Random error.
c Reproducibility
a

d Foroducinty

For samples with avg above $0.15 \mathrm{ggcm}^{-2}$ of $\mathrm{EC}$.

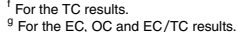

${ }^{9}$ For the $\mathrm{EC}, \mathrm{OC}$ and $\mathrm{EC} / \mathrm{TC}$ results.

For the thermal-optical methods only.
For the two labs using EUSAAR_1 only.

For the two labs using EUSAAR_1 only.
I For the labs using NIOSH or quartz only.

${ }^{k}$ EUS te laR partners only.

I EUSAAR associates only

$\mathrm{m}$
${ }^{n}$ EUSAAR_2 only.
NIOSH-like only.

${ }^{n}$ NIOSH-like only.
- EMEP laboratories only.

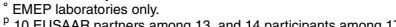

${ }^{9} 6$ EUSAAR partners among 11,9 participants among 15 , and 9 participants among 12 using EUSAAR_ 2

For samples with avg above $1.4 \mathrm{\mu g} \mathrm{cm}^{-2}$ of OC.
$\mathrm{s}^{\mathrm{s}}$ For samples with avg above $1.5 \mathrm{\mu g} \mathrm{cm}^{-2}$ of TC.

${ }^{\mathrm{t}}$ For samples with $\mathrm{EC} / \mathrm{TC}$ avg above 0.10 .

TOT: thermal-optical transmission

TOR: thermal-optical reflectance.

\section{AMTD}

8, 9649-9712, 2015

\section{Measurement of elemental carbon (EC) and organic carbon (OC)}

A. Karanasiou et al.

\section{Title Page}

Abstract

Introduction

Conclusions

References

Tables

Figures

14

4

Back

Full Screen / Esc

Printer-friendly Version

Interactive Discussion 
Table A1. List of Acronyms and abbreviations.

\begin{tabular}{ll}
\hline BC & Black carbon \\
BrC & Brown carbon \\
CC & Carbonate carbon \\
CEN & European Committee for Standardization \\
DRI & Desert Research Institute \\
EC & Elemental carbon \\
EMEP & Convention on long-range transport of air pollutants \\
EUSAAR & European supersites for atmospheric aerosol research \\
FID & Flame ionization detector \\
IC & Inorganic carbon \\
IMPROVE & Interagency monitoring of protected visual environments \\
LAC & Light absorbing carbon \\
NIOSH & National institute of occupational safety and health \\
OC & Organic carbon \\
PC & Pyrolitic carbon \\
RSD & Relative standard deviation \\
SD & Standard deviation \\
SVOCs & Semi-volatile organic compounds \\
TC & Total carbon \\
Tmax & Maximum temperature in the inert mode \\
TOA & Thermal-optical analysis \\
TOR & Thermal-optical reflectance \\
TOT & Thermal-optical transmittance \\
TSP & Total suspended particles \\
WSOC & Water-soluble organic compounds \\
TOT EC & EC determined by TOT methood \\
TOR EC & EC determined by TOR method \\
VMM & Flemish Environment Agency \\
\hline
\end{tabular}

AMTD

8, 9649-9712, 2015

Measurement of elemental carbon (EC) and organic carbon (OC)

A. Karanasiou et al.

Title Page

Abstract Introduction

Conclusions References

Tables

Figures

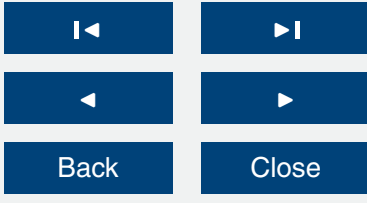

Full Screen / Esc

Printer-friendly Version

Interactive Discussion 


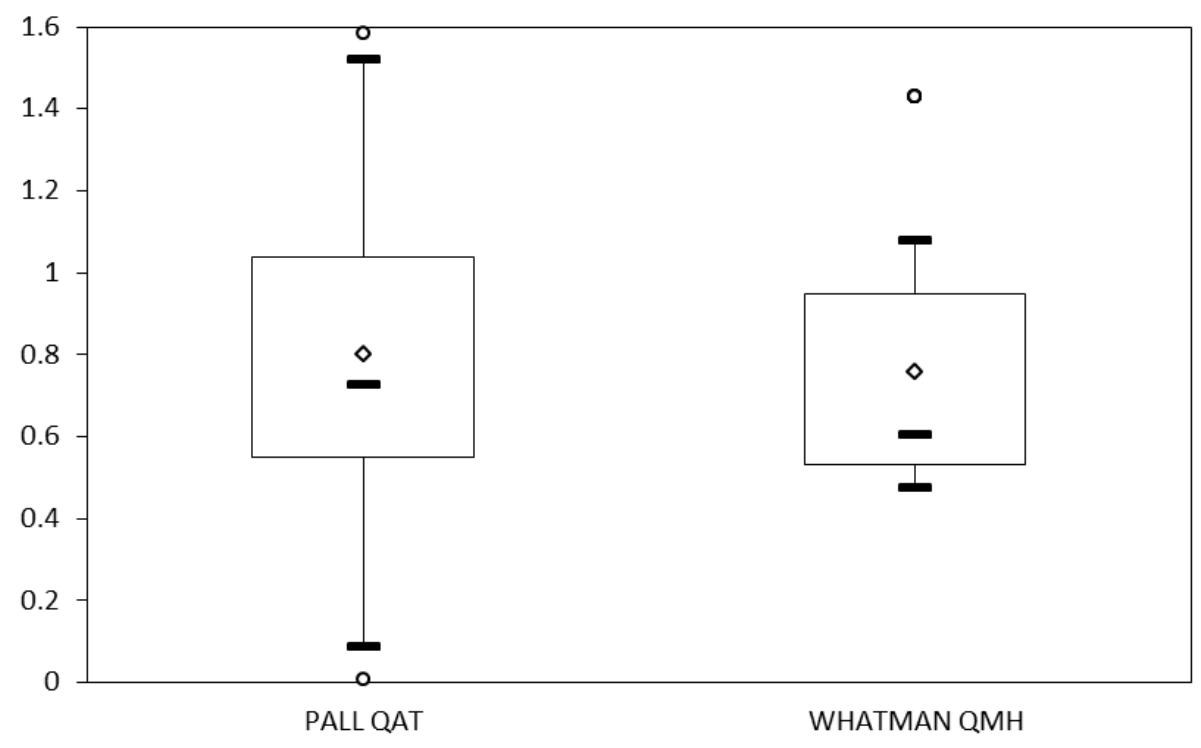

Figure 1. Mean, median, and 25 and 75 percentiles of the $O C$ blank concentration $\left(\mu \mathrm{g} \mathrm{cm}^{-2}\right)$ determined for Pall Tissuquartz filters 2500-QAT, $150 \mathrm{~mm}$ (QAT, $n=128$ ) and ultra-pure Quartz filters, $150 \mathrm{~mm}(\mathrm{QM}-\mathrm{H}, n=127)$ determined in the IDAEA-CSIC laboratory in the period 20122014 (CSIC, unpublished results).

\section{AMTD}

8, 9649-9712, 2015

\section{Measurement of elemental carbon (EC) and organic carbon (OC)}

A. Karanasiou et al.

\section{Title Page}

Abstract

Introduction

Conclusions

References

Tables

Figures

14

4

Back

Full Screen / Esc

Printer-friendly Version

Interactive Discussion 